University of Louisville

ThinkIR: The University of Louisville's Institutional Repository

Electronic Theses and Dissertations

$12-2020$

\title{
Impacts of environmental and hydrologic factors on urban stream water quality.
}

Jason Patrik Ingram

University of Louisville

Follow this and additional works at: https://ir.library.louisville.edu/etd

Part of the Civil Engineering Commons

\section{Recommended Citation}

Ingram, Jason Patrik, "Impacts of environmental and hydrologic factors on urban stream water quality." (2020). Electronic Theses and Dissertations. Paper 3563.

https://doi.org/10.18297/etd/3563

This Master's Thesis is brought to you for free and open access by ThinkIR: The University of Louisville's Institutional Repository. It has been accepted for inclusion in Electronic Theses and Dissertations by an authorized administrator of ThinkIR: The University of Louisville's Institutional Repository. This title appears here courtesy of the author, who has retained all other copyrights. For more information, please contact thinkir@louisville.edu. 


\title{
IMPACTS OF ENVIRONMENTAL AND HYDROLOGIC FACTORS ON URBAN STREAM WATER QUALITY
}

\author{
By \\ Jason Patrik Ingram \\ B.S., University of Kentucky, 2016
}

\begin{abstract}
A Thesis Submitted to the Faculty of the J.B. Speed School of Engineering of the University of Louisville in Partial Fulfillment of the Requirements for the degree of

Master of Science of Civil Engineering

Civil and Environmental Engineering University of Louisville

Louisville, Kentucky
\end{abstract}

December, 2020 



\title{
IMPACTS OF ENVIRONMENTAL AND HYDROLOGIC FACTORS ON URBAN STREAM WATER QUALITY
}

\author{
By \\ Jason Patrik Ingram
}

A Thesis Approved on

November 11, 2020

By the following Thesis Committee

Dr. Nageshwar R. Bhaskar

Dr. Mark French

Dr. Tamara Sluss 


\section{DEDICATION}

I dedicate this thesis and the work I put into it to my friend, Richard Alex Mucci, P.E., to my girlfriend, Jillian Andrea Walls, And to my parents Sylvia \& Theodore Ingram Who all had their own role in my arrival to this point 


\section{ACKNOWLEDGEMENTS}

The work completed within this thesis is the product of the guidance and education of some exceptional people. I am thankful for all of the hard workers at the United States Geological Survey (USGS) and the Salt River Watershed Watch (SRWW) that provided me with the tools and training necessary for this project. Specifically Karen Schaffer and Joann Palmer for their dedication to the watershed watch.

I also wanted to express my gratitude for staff at the University of Louisville. Thank you to Russ Barnett for his commitment to educating and training through his work at USGS and SRWW. Also, Dr. Deborah Yoder-Himes for not only allowing the use of her lab and the equipment within, but for her guidance through experimental processes. It meant a lot that they were willing to help students outside of the classroom.

I want to also acknowledge the professors at the University of Louisville who dedicated themselves to being a part of my thesis committee. Dr. Mark French, PhD PE for his education and counsel on matters of water resources with this project. Dr. Tamara Sluss, $\mathrm{PhD}$ for educating me on a new perspective to this project with her ecologist background and guiding through utilizing ecological principles within this engineering project. Finally, a sincere thank you to Dr. Nageshwar Bhaskar, PhD PE who advised this projects completion and taught me many subjects in water resources. 


\section{ABSTRACT \\ IMPACTS OF ENVIRONMENTAL AND HYDROLOGIC FACTORS ON URBAN STREAM WATER QUALITY}

Jason Patrik Ingram

December 12, 2020

Urban streams can be impacted by a multitude of hydrologic and environmental factors, making maintaining these water sources difficult. Urbanization can exacerbate these impacts creating new challenges in preserving suitable urban stream water quality. Urbanization is the development of city landscape and suburban living within an otherwise natural region. For this environmental impact study, the effects of city development on urban stream water quality was monitored for Mill Creek in Louisville, Kentucky. To study the effects of urbanization on Mill Creek, this project was completed utilizing the BACI method for comparing impacts. The results of the water quality monitoring were acceptable for water quality standards in Kentucky in the categories of $\mathrm{pH}$, water temperature, and conductivity from July 19th to August 14th of 2019. The dissolved oxygen concentration in the creek was below the standard for Kentucky regulations. The e. coli concentration of the studied creek were above regulations for state water quality standards in almost the entire stretch of Mill Creek (5 of 6 sampling locations). The e. coli was highest on the days of precipitation, while the dissolved oxygen was lowest in times of limited to no rainfall with rising temperatures. The e. coli 
concentration was a result of the high percentages of impervious pavements within the region leading to runoff of pollutants residing on urban surfaces. The dissolved oxygen was a result of reduced mixing of the water column in low flow with no rainfall. The conclusion was that urbanization is having an effect on these two parameters and will continue to deteriorate these water conditions if trends in city runoff and environmental destruction continue. 


\section{TABLE OF CONTENTS}

PAGE

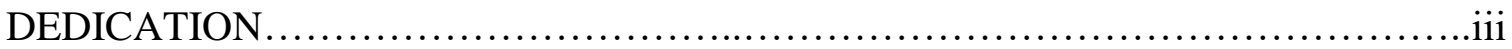

ACKNOWLEDGEMENT .............................................................

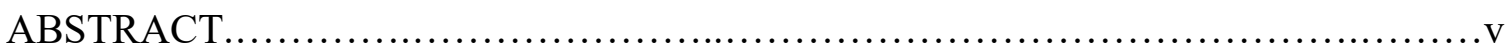

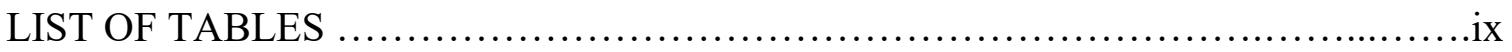

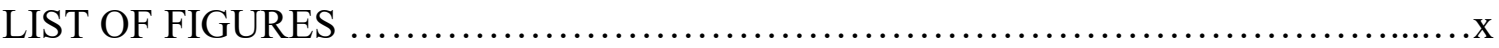

CHAPTER

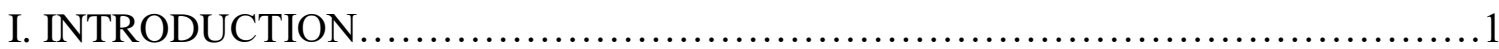

1.1 Introduction

1.2 Organization

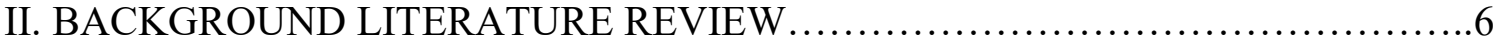

2.1 Introduction

2.2 Background

2.3 Terminology

2.4 Organizations

2.5 Water Quality Standards

III. ENVIRONMENTAL AND HYDROLOGIC FACTORS .20

3.1 Introduction

3.2 Hydrologic Factors

3.3 Environmental Factors \& Impacts

IV. RESEARCH PROCEDURES. .25

4.1 Introduction

4.2 Before-After-Control-Impact (BACI) method 
4.3 Study Area

4.4 Water Quality Tests

V. RESULTS

5.1 Introduction

5.2 Environmental and Hydrologic Factors

5.3 Water Quality and Climate Data

VI. SUMMARY, CONCLUSIONS, AND RECOMMENDATIONS...................74

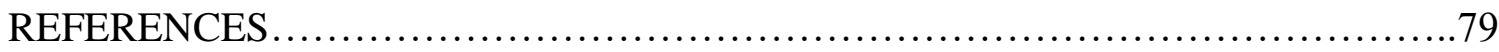

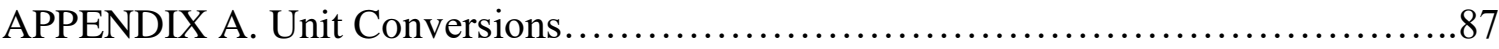

APPENDIX B. Maps with Sampling Locations Coordinates...........................88

APPENDIX C. Mill Creek Precipitation Events Calendar (NOAA, 2020).................90

APPENDIX D. NOAA Data Table for Total Precipitation in Mill Creek

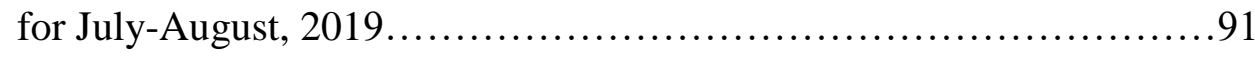

APPENDIX E. Climate Trends for Jefferson County and

The Greater Midwest Region.......................................93

APPENDIX F. Project Photographs................................................. 96

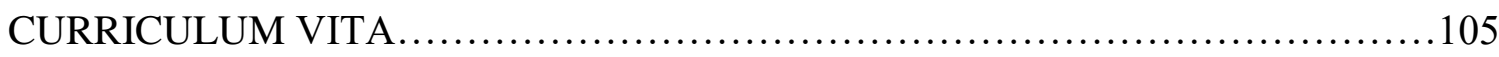




\section{LIST OF TABLES}

TABLE

PAGE

4.1 Calendar of Summer 2019 Testing of Control and Impact Stream.................36

4.2 Calendar of Summer 2019 Testing of Mill Creek..................................36

4.3 401 KAR 10:031 Surface Water Standards for Water Temperature Average and Instantaneous Maximums...........................41

5.1 Beargrass Creek Results from Water Quality tests and Climate data................52

5.2 Beargrass Creek Average E. Coli Concentrations per $100 \mathrm{~mL}$ of sample.............53

5.3 Wilson Creek Results from Water Quality tests and Climate data..................54

5.4 Wilson Creek Average E. Coli Concentrations per $100 \mathrm{~mL}$ of sample...............55

5.5 Mill Creek Results from Water Quality Tests and Climate data

(a) July, 2019 Testing Period...................................57

(b) August, 2019 Testing Period...................................58

5.6 Mill Creek Average E. Coli Concentrations per $100 \mathrm{~mL}$ of sample................69 


\section{LIST OF FIGURES}

FIGURE

PAGE

4.1 South Fork Beargrass Creek Sampling locations- Satellite image. ...

4.2 South Fork of Beargrass Creek MSD Map of CSO/SSO Locations with Sampling Location Circled in Orange (MSD, 2020)...............29

4.3 South Fork Beargrass Creek Watershed with upstream (us) and downstream (ds) sampling locations

4.4 Location of Wilson Creek.................................................... 31

4.5 Wilson Creek in Bernheim Forest Sampling Locations..........................32

4.6 Mill Creek Sampling Locations within Watershed............................33

4.7 Dissolved Oxygen concentrations in a stream over one day......................40

4.8 Dissolved Oxygen concentration vs Temperature in a river system.................42

4.9 Filtration Apparatus Diagram............................................ 45

4.10 Example Results of Membrane Filtration Method

(a) Beargrass Creek Upstream Grab sample (BGUG) example results $(6 / 22 / 19)$ 
(b) Wilson Creek Upstream \& Downstream Grab sample example results $(6 / 28 / 19)$

(c) Mill Creek example grab (G) sample results for sites 4, 5, $6(7 / 17 / 19)$.

$5.1 \mathrm{pH}$ Average for the 6 gaging sites for Mill Creek

5.2 Water Temperature Average for the 6 gaging sites for Mill Creek.

.60

5.3 Conductivity Average for the 6 gaging sites for Mill Creek.......................60

5.4 Mill Creek Dissolved Oxygen Concentrations for sites 1-6

(a) DO Concentrations for site 1 on Mill Creek 61

(b) DO Concentrations for site 2 on Mill Creek 62

(c) DO Concentrations for site 3 on Mill Creek

(d) DO Concentrations for site 4 on Mill Creek .62

(e) DO Concentrations for site 5 on Mill Creek

(f) DO Concentrations for site 6 on Mill Creek.

5.5 DO Concentrations of Control \& Impact sites vs Mill Creek sites .65

5.6 Mill Creek E. Coli Concentrations for sites 1-6

(a) E. Coli Concentrations for site 1 on Mill Creek

(b) E. Coli Concentrations for site 2 on Mill Creek .67 
(c) E. Coli Concentrations for site 3 on Mill Creek............................68

(d) E. Coli Concentrations for site 4 on Mill Creek.............................68

(e) E. Coli Concentrations for site 5 on Mill Creek.............................68

(f) E. Coli Concentrations for site 6 on Mill Creek..........................69

5.7 E. Coli Concentration per $100 \mathrm{~mL}$ of sample: 30-day average

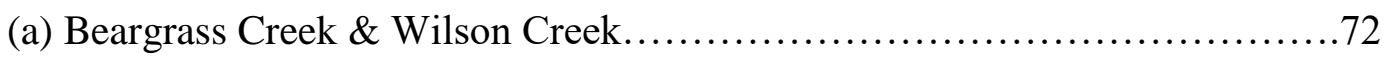

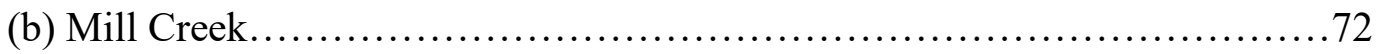




\section{CHAPTER 1}

\section{INTRODUCTION}

\subsection{Introduction}

Urbanization has been leading to a sprawl effect that is rapidly affecting the countries natural waterways, resulting in more urban streams. These urban streams are often heavily manipulated to the extent that the biodiversity and the overall water quality of the stream is negatively impacted. The objective of this project is to analyze the water quality of an urban stream to examine the effect of environmental and hydrologic factors of the region, including urbanization. The environmental and hydrologic effects within the study region will be detailed from climate data of the region and information pertaining to the current environmental conditions of the urban stream. The particular climate data emphasized in this study are temperature and precipitation.

The project began as an opportunity to test water quality of natural streams through the United States Geological Survey (USGS). USGS trains volunteers to test water samples of local streams in Jefferson County, Kentucky in a program called the Salt River Watershed Watch (SRWW). The results are then added to an online database for the public to use and to help discover any problems with the water quality in the area. The stream chosen for this project is a stream that Louisville/Jefferson County Metropolitan Sewer District (MSD) listed as being an impacted waterway with "poor 
stream habitats" (Parrott, 2016). The urban stream focused on for this assessment is Mill Creek. Located in the West end of Louisville, Kentucky, this stream has the second most area of urban or suburban land around it in the state of Kentucky (Parrott, 2016). Urban areas contain higher percentages of pavements that are impervious, like concrete or asphalt, that lead to an increase in runoff during storm events because the water cannot penetrate to the soil holding the groundwater below. The majority of the land in this stream's watershed is residential and commercial, leading to $31.7 \%$ being listed as impervious areas that do not allow for infiltration of runoff to the groundwater in the soil below (Waters of, 1999).

Mill Creek has a watershed that is about 34.2 square miles and contains 71 miles of streams (Louisville MSD, 2017). The first stream in the watershed that comes off the Ohio River is called the Mill Creek Cutoff. The Mill Creek Cutoff does not drain directly to Mill Creek and is separated by a flood plain before Mill Creek starts. Mill Creek is considered a small surface runoff stream collecting water from precipitation and snow melt. At the upstream most point of the stream is a wetland that contains water year round. There are several small tributaries along the stream that discharge more surface runoff into the main channel. This runoff that drains to the beginning wetland and from the tributaries comes from residential, industrial, commercial businesses, and highways with the main road being Dixie Highway. While Jefferson County has combined sewer overflows (CSO) and sanitary sewer overflows (SSO) throughout, MSD reports that Mill Creek does not have any overflows discharging into the main channel or one of the tributaries (Louisville MSD, 2017). The stream's outlet is the Ohio River through smaller streams not listed under federal recognition. 
The standards for water quality of Mill Creek are set at two levels of government. The Kentucky Energy and Environment Cabinet sets the standards of quality for the state to maintain the stream and the Environmental Protection Agency (EPA) is the federal agency to hold the state accountable to these standards (Kentucky Energy, 2020). The state guidelines are set for Mill Creek to be used safely for recreational activities. MSD and the USGS monitors these waters and report on whether the quality is up to these standards or not. Currently, USGS has 1 active monitor on this stream to measure discharge and relies on volunteers with SRWW to report quality data while MSD monitors water quality of the 27 main streams in Jefferson County 4 times a year (USGS, 2019) (Water Quality, 2016).

Urban streams are more at risk of impairment from surface runoff due to substances residing on impervious pavements (Viessman, 2015). Substances, such as oil, grease, or pesticides, all can runoff with stormwater into the stream when these substances cannot penetrate the soil beneath (Viessman, 2015). The overall goal of this study is to examine urbanization and the effect it has on this urban stream using data of the water quality that will be analyzed as it pertains to the environmental factors surrounding. The hypothesis is that urbanization and increases in impervious land use is causing degradation of urban water quality. This will be proven true if the data shows that poor water quality is exhibited in the urban stream during events of rainfall or when atmospheric temperatures rise compared to a rural control stream. Based on trends in the research completed for this project, poor water quality would be expected to be higher in fecal coliform bacteria, such as e. coli, and lower $\mathrm{pH}$ and oxygen concentrations. 


\subsection{Organization}

This first chapter of this thesis is the introduction and it identifies the problem area of the study. Information from local municipalities and relevant literature is used to describe the current scenario faced by the area of focus. This will set the stage and act as a blue print of the experiments conducted in this study.

The second chapter is the background literature review. In this chapter, definitions, terminology, abbreviations, and organizations will all be explained. This section should be referred back to for more clarity of the terminology used herein. Background information will also be established as items necessary to know before continuing into the project.

The third chapter is titled "Environmental and Hydrologic Factors." This chapter will identify what has been discovered about how urbanization of the environment around a stream affects the water quality. Literature will also be reviewed to show recent findings on how these changes are impacting environments and water quality.

The fourth chapter will present the research procedures. The overall design of the experiment will be analyzed by sharing what instructions need to be followed to collect the data necessary for this project. This will examine all the procedures followed in testing the water. The equipment used in this study to perform the experiments and collect data will also be identified, along with how each was used. An identification of the research methodology will we be present in this section, as well.

The fifth chapter is about the results. These results will be a product of the water sampling data and the environmental conditions of the area during this testing period. The 
collected data using the procedures discussed in Chapter 4 will also be examined in detail.

The sixth and final chapter will be the summary, conclusions, and recommendations. A summary of the results will be outlined here. Recommendations will come as a result of what measures should be taken to change any problem areas discovered in the project. 


\section{CHAPTER 2}

\section{BACKGROUND LITERATURE REVIEW}

\subsection{Introduction}

This chapter will provide background information on water quality and potential impacts to freshwater systems. All definitions, acronyms, organizations, and abbreviations that are involved with this topic will be explained in this section.

\subsection{Background}

Urban streams often require more maintenance to improve water quality than natural streams. The negative impacts of humans activity is strenuous on natural habitats and with urban areas, impacts to nature are higher because populations are higher than natural areas away from development. These impacts can come in the form of point source pollution, nonpoint source pollution, encroachment due to development, redirection of flow, damming, or concrete channelization. This list, along with other possibilities, are all furthered enhanced by inclement weather such as precipitation, low rainfall periods, or high temperatures. One of the primary goals of this project will be to identify what effect an urban environment with high percentages of impervious land and reduced natural features has on the quality of a water system within.

Urbanization has a multitude of effects on a streams water quality within the area of the development. Some of these effects are immediate and some are long terms issues 
for streams in this dynamic environment. With urban development, there is an increase in impervious pavements in the form of concrete, asphalt, and other hard surfaces that prevent seepage of stormwater to the groundwater layers below (Urbanization, 2020). Therefore, there will be increases in stormwater runoff, sediment load runoff, and the pollutants discharging into the river from urban surfaces all effecting the water quality of the streams with each storm after construction is completed (Hamid, 2020). Flooding and erosion are also a concern for streams near new urbanization due to the change in drainage or removal of trees and hills for urban construction. Because there are less natural features to reduce discharge rates, higher flow rates of runoff can occur that can erode channels or banks (Urbanization, 2020).

For long term effects of urbanization, one concern is the groundwater table becoming lower because of the inability of runoff to seep into the groundwater table recharging it (Hamid, 2020). Without this recharge, the water depth of the stream can decrease from lack of groundwater maintaining the water level (Hamid, 2020). Water quality will continue to be impacted, as well, by surface runoff pollutants from urban sectors (Urbanization, 2020). As time goes on, more pollutants from runoff of urban sectors will degrade the water quality of the stream, like grease, oil, pesticides, or sediments. Storm events will also have more of an impact on the urban stream due the fact that there is less groundwater penetration or natural features to reduce runoff into the stream. This means a 1-month, 1-year, 10-year, and 100- year event all increase in magnitude in their risk of flooding due to the removal of systems that previously reduced the impacts of these storms (Urbanization, 2020). 
Over time, the water quality can also be impacted by increasing temperatures without coverage from natural features for shading (Hamid, 2020). In many cities, higher temperatures are experienced in the urban sectors compared to those temperatures of a rural area (Mohajerani, 2017). This phenomenon is known as the Urban Heat Island Effect. This occurs when multiple urban design features causes temperatures to rise (Mohajerani, 2017). Examples of these warming urban features are dark hued impervious pavements and rooftops that are exposed to solar radiation or high levels of carbon dioxide from transportation, therefore absorbing the heat emitted from the sun (Mohajerani, 2017). The result is higher temperatures within the city and the streams flowing within (Mohajerani, 2017). As rainfall puddles on these impervious surfaces collecting pollution, the runoff is also heated by the heat absorbed by the dark colored roads, as well. The surface runoff will then be warmer as the water enters the storm systems and discharges into urban streams (Somers, 2016). Results from one study conducted on this warmer water surface runoff, found that urban streams were on average 7 degrees warmer during rain events because of this surface water heating (Somers, 2016). Water quality for a stream within a city with rising temperature can be degraded due to oxygen concentration reduction, heat pollution by warm water runoff, and disrupting ecosystems within by creating an unlivable habitat for organisms (Somers, 2016) (Allan, 2007).

Water quality for this project is for recreational standards only and not those that apply domestic consumptive uses. Mill Creek is not a drinking water source for humans and does not have a drinking water treatment plant. Instead this projects focuses on water quality of a natural habitat that is being impacted by urban development. The features 
monitored for the creek are dissolved oxygen (DO), $\mathrm{pH}$, water temperature, conductivity, and e. coli concentrations. These are the parameters the United States Geological Survey (USGS) use to identify water quality (USGS Water, 2020). The standards for the quality of the water in Kentucky are set by two organizations: the federal government through the Environmental Protection Agency (EPA) and the state government through the Kentucky Energy and Environment Cabinet. Also, climate data will be necessary to identify, for example the atmospheric temperature, the rainfall volume, and the number of days without rainfall. The National Oceanic and Atmospheric Administration (NOAA) collects this data and provides this information for various areas across the United States (Climate data, 2020).

As stated in chapter 1 , one of the objectives is to identify any correlations between urbanization and the quality of water in an urban stream. Similar studies have been conducted around the world. In Atlanta, GA, a study was conducted of urban streams water quality in reference to natural streams not impacted by urbanization (Peters, 2009). The study monitored the urban stream for concentrations of fecal coliform, heavy metals, and other parameters of water quality, such as $\mathrm{pH}$ (Peters, 2009). Results of the testing indicated that the water contained high levels of fecal coliform bacteria that were above state regulations (Peters, 2009). The waters through the city were also found to have low alkalinity, heavy metals, and a pH less than 5 (Peters, 2009). Tracing the metals found in the water allowed the study to conclude that surface runoff was contributing to these impairments by discharging impervious pavement pollutants (Peters, 2009). 
Similar studies have yielded results comparable to those found in Atlanta. In Formosa, Goias State, Brazil, a water quality study was conducted of a river flowing through this growing city (Pires, et al. 2015). The Preto River was tested at five locations at various distances to identify which locations near the city were having the largest impact (Pires, et al. 2015). The results of the study indicated that high concentrations of fecal coliform and excess nutrients were present in the water (Pires, et al. 2015). Overflows where sewage discharged into the water were determined as the source of these high concentrations and required a public health advisory for the residents of the town who used the water for bathing (Pires, et al. 2015). These results align with those of a study of nine urban water ways of varying urban intensity classes in Suzhou, China (Yuan, 2019). This experiment lead to the determination that "urbanization negatively impacts water quality" (Yuan, 2019). The results of this study presented evidence of high levels of nutrient runoff and fecal coliform bacteria that contained pathogens (Yuan, 2019).

Similarly, population has been studied for the correlation between it and impacts to parameters of water quality. In 2017, a correlation analysis was conducted on these two factors in Sri Lanka in Asia (Liyanage, 2017). The results were high correlations (above or equal to 0.69 ) between population and impacts to three parameters of water quality (Liyanage, 2017). The parameters that were impacted were biological oxygen demand, dissolved oxygen, and total coliform (Liyanage, 2017). These results are comparable with those identifying urbanization as the factor because the rise in population creates a demand for housing and other amenities (Liyanage, 2017). The studies in this section, along with research completed on this topic, indicate that for 
urbanization to have a noticeable impact on an urban creek, evidence of fecal coliform, nutrient loading, or degraded water quality parameters should be present in the results.

\subsection{Terminology}

Definitions, abbreviations, and acronyms are all explained to allow for proper interpretation of the results found from Mill Creek.

- $\mathrm{pH}$ : a measurement of the concentration of hydrogen ions $\left(\mathrm{H}^{+}\right)$within an aqueous solution. The equation for $\mathrm{pH}$ is below:

$$
\mathrm{pH}=\log \frac{1}{\left[H^{+}\right]}
$$

The scale for measuring $\mathrm{pH}$ is a logarithmic scale ranging from 0 to 14 with 7 representing neutral solutions, such as pure water. Any solution with a $\mathrm{pH}$ below 7 is classified as acidic and above 7 as basic. Each value on the scale is a change of 10 times gram moles per liter of hydrogen ion concentration (Viessman, 2015).

- Conductivity: a measurement of the ability of a water system to maintain a current. The units for conductivity is micro Siemens per centimeter $(\mu \mathrm{S} / \mathrm{cm})$. The conductivity of a water system is altered by the presence of inorganic dissolved solids and organic compounds (5.9 Conductivity, 2012).

- Dissolved Oxygen (DO): a measurement of the amount of oxygen available in the water. The units for DO in this project is ppm $=$ parts oxygen per million of total molecules (Henry, 1996).

- Biological Oxygen Demand (BOD): The oxygen used by bacteria to consume decaying organisms in the aerobic water (Henry, 1996) 
- Fecal Coliform Bacteria: a large group of bacteria that combine to culture as a single group. These are found naturally occurring in the intestine of warmblooded animals. These microorganisms can be pathogenic causing sickness in people when consumed (Community, 2020)

- Escherichia Coli (E. Coli): A commonly found fecal coliform bacteria (Community, 2020). This bacterium is described as "Gram-negative, rod-shaped, facultative and anaerobic" (Lim, 2010). It comes from the intestine of warmblooded animals and can become present in areas with sewage discharge containing human excrement (Community, 2020). The presence of e. coli can put the water source at risk of pathogens. (Community, 2020).

- Fecal Indicator organism (FIO): a term for bacteria present in the intestines of warm-blooded animals. These bacteria are not are always harmful to humans (Haack, 2017).

- Harmful algal bloom (HAB): An excessive growth of phytoplankton which grows into a large floating algae that releases toxins (microcystin) and contaminates water sources making it unsafe to consume. These blooms can cause fish kills, increases in E.coli concentrations, and only can be eliminated by rain events that mix the water column (Hilborn, 2014).

- Climate Change: "changes in the usual weather of any area or of the Earth" (Dunbar, 2015).

- Before After Control Impacted (BACI): A method of experimental design used to determine the impact (often human) on a system. BACI is an acronym meaning: 
Before $=$ Past data or observed data on the main test subject (i.e. Mill Creek)

After $=$ Results of the experiment to identify used to identify the impact on the main subject (i.e. Mill Creek) based on the change from the before data

Control = An unaffected subject that is used for comparison with the main subject (i.e. Wilson Creek)

Impacted $=$ An affected subject that has experienced an impact for comparison to the main subject (i.e. Beargrass Creek)

Another name for this method is the hierarchical Bayesian method using Markov chain Monte Carlo (Conner, 2015). For this project, each system will be local streams.

- Combined Sewer Overflow (CSO): a system of transporting domestic wastewater, stormwater, and industrial waste. The system will allow storm water to overflow when the storm water system is overwhelmed. When this occurs, the result is wastewater discharging into local streams before it can be treated at a sewage treatment plant. The EPA has pushed to reduce the impact and eventual elimination of the systems across the country. A CSO is considered a point source pollution when it enters water (Combined, 2018).

- $\quad$ Sanitary Sewer Overflow (SSO): These systems are not designed to collect storm water, but can discharge raw sewage into water systems due to a multitude of failures or overflows. An SSO is considered a point source pollution when it enters water (Sanitary, 2016). 
- Nonpoint Source Pollutions: Pollutants that result from runoff of rainfall or snowmelt on the surface or in the ground from many diffuse sources. The exact source of the pollution cannot be determined as the runoff collectively comes from multiple sources. The EPA reports that states claim nonpoint source pollution is the main cause of water quality impairment (Basic, 2018). A few examples of nonpoint source pollution from the EPA (2018) include:

* Excess fertilizers, herbicides, and insecticides from agricultural lands and residential areas

* Oil, grease, and toxic chemicals from urban runoff and energy production Sediment from improperly managed construction sites, crop and forest lands, and eroding streambanks

* Salt from irrigation practices and acid drainage from abandoned mines Bacteria and nutrients from livestock, pet wastes and faulty septic systems Atmospheric deposition and hydromodification

- $\quad$ Point Source Pollutions: "any single identifiable source of pollution from which pollutants are discharged, such as a pipe, ditch, ship, or factory smokestack" (Basic, 2018).

- $\quad$ Palmer Drought Severity Index (PDSI): This index used by the National Oceanic and Atmospheric Administration (NOAA) is a scale to indicate the severity of a drought for a region (NOAA, 2020). The value range NOAA utilizes for maps is 4 (dry) to +4 (wet) (NOAA, 2020).

- $\quad$ Lotic: A water system with flowing water (fluvial or fluviatile) (Marsh, 1999). 
- Million Gallons per Day (MGD): Units for water discharge, Q, as a volume per time

- Cubic Foot per Second (CFS): Alternative units for measuring discharge, Q.

\subsection{Organizations}

The following is a list of the various companies, organizations, and agencies involved with monitoring water quality conditions. The involvement of these groups can range from engineering solutions to being a database for water parameter data. To understand the roles of each organization will be necessary for determining the involvement needed from each in solutions of the problems discovered in this project.

- Metropolitan Sewer District (MSD): MSD is a non-profit regional utility service in Jefferson County, KY. Within the county, MSD manages systems for wastewater, stormwater, and flood protection. Their work involves the network of sewage and storm water systems and treatment of these waters, as well as, monitoring water quality of the urban streams and creating sustainable solutions (Louisville MSD, 2017).

- Environmental Protection Agency (EPA): As a result of the National Environmental Policy Act of 1970, Richard Nixon created the EPA to act as a federal agency with the mission of protecting the air, water, and land from pollution. Roles of the EPA include developing and enforcing regulations, providing grants, studying environmental issues, sponsoring partnerships, teaching, and publishing information (Our Mission, 2018).

- National Oceanic and Atmospheric Administration (NOAA): This agency studies climate around the world using the latest technology. The NOAA collects data on 
weather and temperatures using active monitors and orbiting satellites. Their goals include monitoring the effects of climate change, providing historical climate data and protecting marine coast and resources (About, 2020).

- United States Geological Survey (USGS): This agency provides historical data on water monitoring across the country. While the number of water quality monitors have reduced over time, there are still active monitors in major water bodies. Local agencies across the country have begun training volunteers in water quality monitoring and providing them with equipment. For Louisville, KY the group is called the Salt River Watershed Watch (SRWW). USGS has a database full of historical data on discharges and water quality along with the results reported by watershed watch volunteers (USGS Water, 2020).

- Kentucky Energy and Environment Cabinet: A state level government agency that sets the standards for environmental protection throughout the state of Kentucky. This cabinet develops the Kentucky Administrative Regulations (KAR) that monitoring agencies use to determine the quality of a water way (Kentucky Energy, 2020).

\subsection{Water Quality Standards}

The water quality standards emphasized in this project will be water ways for recreational purposes. The creeks mentioned in this project do not provide drinking water, and will not be regulated as such. The purpose for these regulations are to produce a water quality that can sustain life and is safe for recreational uses for those inhabiting the area. Maintaining water quality for Mill Creek is essential as this water flows into the Ohio River and can serve as a means of discharging pollutants into the river, if they are 
present. The Ohio River is a primary source of drinking water for many states and a large ecosystem to a variety of organisms.

- National Pollutant Discharge Elimination System (NPDES): This U.S. federal system issues permits allowing for the discharge of point source pollution into a water source under monitored conditions. The EPA will allow pollutant discharge if the conditions do not hurt anyone or damage habitats. Additionally, the characteristics of the contaminants must be reported (NPDES, 2019). With this permit, the company discharging will not be penalized for actions opposing the Clean Water Act (CWA).

- Kentucky Pollutant Discharge Elimination System (KPDES): This system is for the state of Kentucky and issues permits similar to the NPDES. The Kentucky Energy and Environment Cabinet allow point source pollution with this permit, but also require reports on the pollution (Kentucky Energy, 2020).

- Clean Water Act (CWA): Beginning in 1948 as the Federal Water Pollution Control Act, the idea behind the CWA was to regulate discharge pollution into American waterways and to create standards to maintain the quality of the water at (Summary of the Clean Water Act, 2019). In 1972, the act adopted the name the "Clean Water Act" and the EPA has since used it as a system to regulate the pollution discharging into our natural water ways (Summary of the Clean Water Act, 2019). Through the CWA, the EPA instructs states on proper maintenance on navigable water ways, as well. If a water body is found not to be up to standard, the unpermitted polluting party, whether it be a state or company, will receive a 
consent decree with fines and penalties for these actions in accordance under this act (Summary of the Clean Water Act, 2019).

- Kentucky Administrative Regulations (KAR): For the state of Kentucky, the KAR are a list of the laws and regulations the state creates (Kentucky General, 2020). The KAR set by that state for water quality under the CWA and Environmental Protection is the following: "TITLE 401 - ENERGY AND ENVIRONMENT CABINET - DEPARTMENT FOR ENVIRONMENTAL PROTECTION” (Kentucky General, 2020).

401 KAR 10:031. Surface water standards:

Below are excerpts from the Kentucky Energy and Environment Cabinet surface water standards. These excerpts include water quality parameters tested on recreational water that fell in the time period of May $1^{\text {st }}$ through October $31^{\text {st: }}$

- "Dissolved oxygen shall be maintained at a minimum concentration of five and zerotenths (5.0) $\mathrm{mg} / \mathrm{L}$ as a twenty-four (24) hour average in water with WAH use. b. The instantaneous minimum shall not be less than four and zero-tenths (4.0) $\mathrm{mg} / \mathrm{L}$ in water with WAH use"

- "pH shall not be less than six and zero-tenths (6.0) nor more than nine and zero-tenths (9.0) and shall not fluctuate more than one and zero-tenths (1.0) $\mathrm{pH}$ unit over a period of twenty-four (24) hours" 
- "Escherichia coli content shall not exceed 130 colonies per $100 \mathrm{ml}$ as a geometric mean based on not less than five (5) samples taken during a thirty (30) day period. Content also shall not exceed 240 colonies per $100 \mathrm{ml}$ in twenty (20) percent or more of all samples taken during a thirty (30) day period for Escherichia coli”

- "Total dissolved solids or specific conductance shall not be changed to the extent that the indigenous aquatic community is adversely affected"

- "Temperature shall not exceed thirty-one and seven-tenths (31.7) degrees Celsius (eighty-nine (89) degrees Fahrenheit)"

- (Kentucky General, 2020) 


\section{CHAPTER 3}

\section{ENVIRONMENTAL AND HYDROLOGIC FACTORS}

\subsection{Introduction}

This chapter will discuss the environmental and hydrologic effects of urbanization including past studies conducted on this topic. The information in this chapter will explain how the environmental and hydrologic factors of freshwater systems are affected by changes of land use to impervious urban environments.

\subsection{Hydrologic Factors}

For this project, the hydrologic cycle that maintains the water in Mill Creek is the water cycle as it is a surface runoff stream. The water cycle begins with rainfall that will discharge as surface runoff into the stream. Then, as the water absorbs solar radiation, evaporation occurs turning into rain clouds, therefore repeating the cycle (The Fundamentals, 1993). Therefore, hydrologic factors to identify in the streams impact analysis are in the runoff entering the stream, the precipitation levels of the region, or the rate of evaporation from the stream.

One hydrologic factor modifying maintenance strategies of urban streams is climate change. Because of these modifications, the environment and how humans interact with it must be adapted. The definition of climate change is "changes in the usual weather of any area or of the Earth" (Dunbar, 2015). These changes can manifest 
themselves as rising temperatures, extreme weather events like flash floods, alterations to natural cycles, and the consequences that follow these events. An increase in precipitation or a rise in temperatures can be damaging to the quality of an urban stream that depends on runoff from the water cycle (Jalliffier-Verne, 2017).

\subsection{Environmental Factors \& Impacts}

Mill Creek is a freshwater lotic system, so impacts must be studied specifically for this type of water system. Runoff of pollutants coming from industrial, rural, and urban areas all result from rainfall events (Kessler, 2011). While many rely on CSO or SSO for stormwater management, Mill Creek was not constructed to utilize this system. The reason being these designs are no longer considered best practice and are not permitted by the EPA for new construction (Sanitary, 2016). Therefore, cities like Toronto, have redesigned their urban stormwater system with an improved system that can handle larger storm events (i.e. 100-year events) without the risk of sewer overflows (Kessler, 2011). This came in response to a 25-year storm that brought 6 inches of rain in 3 hours that caused the city over $\$ 500$ million Canadian dollars in damages (Kessler, 2011).

Urban pollutants that originate from impervious pavement runoff, as listed by the EPA are:

- Sediment, oil, grease and toxic chemicals from motor vehicles

- Pesticides and nutrients from lawns and gardens

- Viruses, bacteria and nutrients from pet waste and failing septic systems

- Road salts, heavy metals from roof shingles, motor vehicles and other sources 
- Thermal pollution from impervious surfaces such as streets and rooftops (nonpoint source, 2017)

These nonpoint source pollutants accumulate on impervious street tops and are flushed through stormwater systems into natural ecosystems without being treated (nonpoint source, 2017). These pollutants cause destruction to habitats and are linked to fish kills (nonpoint source, 2017). A study in the United Kingdom modeled climate data with water quality parameters in urban streams to predict the quality of the stream over time (Miller, 2017). The study concluded that overflows with these pollutants will increase in all scenarios influenced by increased urbanization and population growth, as well as rises in temperature (Miller, 2017). Similarly, an urban water source, the Adyar River in Chennai, India was modeled for impacts with climate data (Kumar, 2019). The result of the WEAP model predicted that the trends in climate and population growth will have a 26.7\% increase in BOD and a 8.3\% increase in E. coli for the urban water ways (Kumar, 2019). Both studies have suggested that changes must come to urban stormwater runoff systems as trends in precipitation and urban growth will result in increases in pollutant loads discharging if not mitigated or treated (Miller, 2107) (Kumar, 2019).

Another area of concern for urban water quality is precipitation leading to eutrophication (excessive growth of vegetation such as plants) as a result of increases in the amount of runoff. Eutrophication occurs when nitrogen and phosphorous are deposited into a water system from runoff (Thomann, 1993). This phenomena has been studied often near rural areas with farming that utilizes fertilizers containing these nutrients for plant growth (Thomann, 1993). Eutrophication is not limited to rural areas as evidence shows urban and suburban regions with lawns will contain these nutrients in 
their runoff, as well (Thomann, 1993). Once the nitrogen and phosphorous are deposited into the river, phytoplankton will feed on these nutrients causing them to grow in size into a harmful algal bloom. The predator of the phytoplankton that keeps their population under control is the zooplankton, but when a harmful algal bloom occurs the zooplankton are unable to survive the overpowering new plankton population (Thomann, 1993).

Harmful algal blooms occurrences are more frequent after rain events during humid periods (Michalak, 2016). The duration of a bloom depends on when the next mixing event is, but with warm temperatures the water column mixes less and becomes stratified (Burton, 2014). Blooms are eliminated when the water column it resides on thoroughly mixes during a rain event (Michalak, 2016). The harmful algal bloom will reside on the surface of the water, preventing sunlight from reaching the organisms below, like aquatic plants or fish (Burton, 2014). The blocking of sunlight limits the plants ability to complete photosynthesis for glucose production causing their death. As the plants perish, carbon dioxide is released and oxygen is no longer produced through photosynthesis, reducing the dissolved oxygen levels of the water. A reduction of oxygen often leads to a fish kill event that will increase bacteria impairing the water more with higher concentrations of e. coli (Michalak, 2016).

Temperature is another common pollutant to water quality. Urban streams water temperature are susceptible to alterations by either the climate or a nonpoint/ point source pollutant (Nedeau, 2003). When urban sprawl occurs, many industries will develop large factories in these regions and establish them along waterways. The reason for the increase in the quantity of these companies is the rise of population will allow for more workers at these facilities. Once established, industries will discharge their thermal pollution when 
cooling into the waterways. This practice is destructive to habitats and can kill organisms residing below immediately. Then, over time, these hot waters that are discharged will lower dissolved oxygen within the water (Nedeau, 2003).

Similarly, the temperatures of the water rise when urban settings are experiencing the Urban Heat Island Effect, as well (Heat, 2020). Urban Heat Island is a result of large portions of dark colored impervious pavements that absorb solar radiation and large concentrations of carbon dioxide from transportation that locks heat within the urban area (Kolbe, 2019). Another contributor to the rise in city temperatures are the removal of natural features in place of urban infrastructure (Kolbe, 2019). For example, the removal trees left the city streets and sidewalks without proper shading and a source of carbon dioxide reduction through photosynthesis (Kolbe, 2019).

Research has also discovered that warmer waters are habitats for higher concentrations of e. coli causing water borne diseases (Philipsborn, 2016). In a study of disease causing e. coli concentrations in water sources, for every $1^{\circ} \mathrm{C}$ increase from mean monthly temperature, an $8 \%$ rise of in e. coli concentrations were found (Philipsborn, 2016). Similarly, a 2018 study using a hydrodynamic model for e. coli growth in the drinking water supply of Norway found a threefold growth by the year 2075 with increasing temperatures (Mohammed, 2018). 


\section{CHAPTER 4}

\section{RESEARCH PROCEDURES}

\subsection{Introduction}

This chapter will introduce all the procedures and methodology followed during the implementation of the research project. All timelines, locations, and equipment specific to this project are detailed here.

\subsection{Before-After-Control-Impact (BACI) method}

The research methodology used was the Before-After-Control-Impact (BACI) method to analyze the impacts on an area. This method is commonly used for impact studies by ecologist, environmental engineers, and other scientist that monitor the environment. Particularly, BACI is useful in impacts caused by human interactions with

environments (Conner, 2015). The goal of this method to compare the resulting quality of a site that has experienced an impact over time to other sites of varying quality to determine the magnitude of the change (Smith, 2002). Studies pertaining to changes in the environmental or water quality of streams utilize this research method because of the challenge to rationalize results found without an identical site to the studied area for comparison (Smith, 2002). BACI requires comparing the changes found at a study location over time with the data found at a control site, or good water quality gaging site, and an impacted site, or poor water quality gaging site (Conner, 2015). The control site 
and impacted site chosen for the project are not changing over time for the duration of study, but instead fixed values that act as parameters of good and bad for comparison to the main study site. The main site that the project is designed for is monitored for change over time from observed data before to the resulting data of the testing as the after (Conner, 2015). This change in the main subject site of the project is the before and after (B \& A) of BACI. The resulting site values, after the impact or change to the site, are then compared to the control and impacted site to rationalize the status of the resulting site. For example, if the results of the study indicate poor water quality on the study creek, it would be expected to have values similar to what was found on the impacted (I) creek. Also, vice-versa for the Control (C) Creek.

An example of the BACI method to study human impact on an environment is well demonstrated using a 2017 case study in Texas (Long, 2017). Using the BACI Method, an experiment was designed to study the environmental impact over time of construction noise on song bird populations (Long, 2017). The populations were analyzed over the years in nearby locations and compared to the populations close to the site where noise was loudest (the impacted) and a distance further from the site where the noise was not noticeable (the control) (Long, 2017). The comparisons over time to the control and impacted sites allowed for a determination of the environmental impact caused by the construction sites noise (Long, 2017).

This present study focuses on the impact to an urban streams water quality over time. The streams selected in this study were Mill Creek (B \& A), Wilson Creek for the control (C) and South Fork Beargrass Creek for the impacted (I). Mill Creek, in the acronym BACI, was the letters B \& A for the before and after to study the magnitude of 
the effect urbanization has had on the water quality of Mill Creek over time. The before was observed data from MSD on the quality of Mill Creek from their synthesis report of Jefferson County, Kentucky watersheds (Parrott, 2016). The after was the results of the tests conducted in the current study. Each stream had characteristics that made them suitable for each role assigned.

\subsection{Study Area}

At each site data was collected during a one month period with samples taken three times a week. The EPA requires at least five samples in 30 days for an e. coli concentration test. Hence, this was the minimum period for collecting water quality data. Beargrass Creek and Wilson Creek were completed concurrently with one another ranging from the dates June $19^{\text {th }}, 2019$ to July $15^{\text {th }}, 2019$. Mill Creek was tested the following month from July $17^{\text {th }}, 2019$ to August $17^{\text {th }}, 2019$. The division of Mill Creek sites testing period and the Beargrass Creek/ Wilson Creek testing period allowed testing to be completed at dawn at all locations.

\subsubsection{Beargrass Creek}

Beargrass Creek was the stream chosen that is located in an urban environment in Louisville, KY. The stream is divided into three segments: South Fork, Middle Fork, and Muddy Fork, respectively. For this study, the South Fork Beargrass Creek was selected as an impacted (I) stream in the BACI method because of its furthest most location within the urban sections of Louisville, KY relative to the other two sections of Beargrass Creek. Another reason for choosing Southfork of Beargrass Creek was the watershed of the creek contained the highest percentage of urban and suburban land use in a watershed in 
Jefferson County (Parrott, 2016). A third reason being the number of combined-sewer overflows (CSOs) and sanitary sewer overflows (SSOs) located on this stream discharging raw sewage mixed in with storm water during rain events. Figure 4.2 displays the locations of these overflows relative to the sampling location for the experiment. This CSO activity, without treatment of overflowed discharge, has led to the EPA issuing a consent decree against MSD for the damage it has caused to the water quality (Consent, 2005). The water quality at the MSD gauge, upstream from the sampling location, was reported in the 2016 synthesis report as fair-to-poor in categories of fecal coliform, algae, and dissolved oxygen (DO) (Parrott, 2016). There were also trends indicating an increase for fecal coliform and a decrease in DO (Parrott, 2016). Water temperature was listed as good by their standards, but the overall the habitat was listed as poor (Parrott, 2016). Problems like these are noticed at the location with the odor being prominent when approached. Figure 4.1 displays the sampling locations on Beargrass Creek with the top arrow being upstream and the bottom arrow being downstream. Figure 4.3 exhibits these sampling locations relative to the watershed for the creek. For this watershed, the upstream location is located south of the downstream as the river flows North towards the Ohio River. 


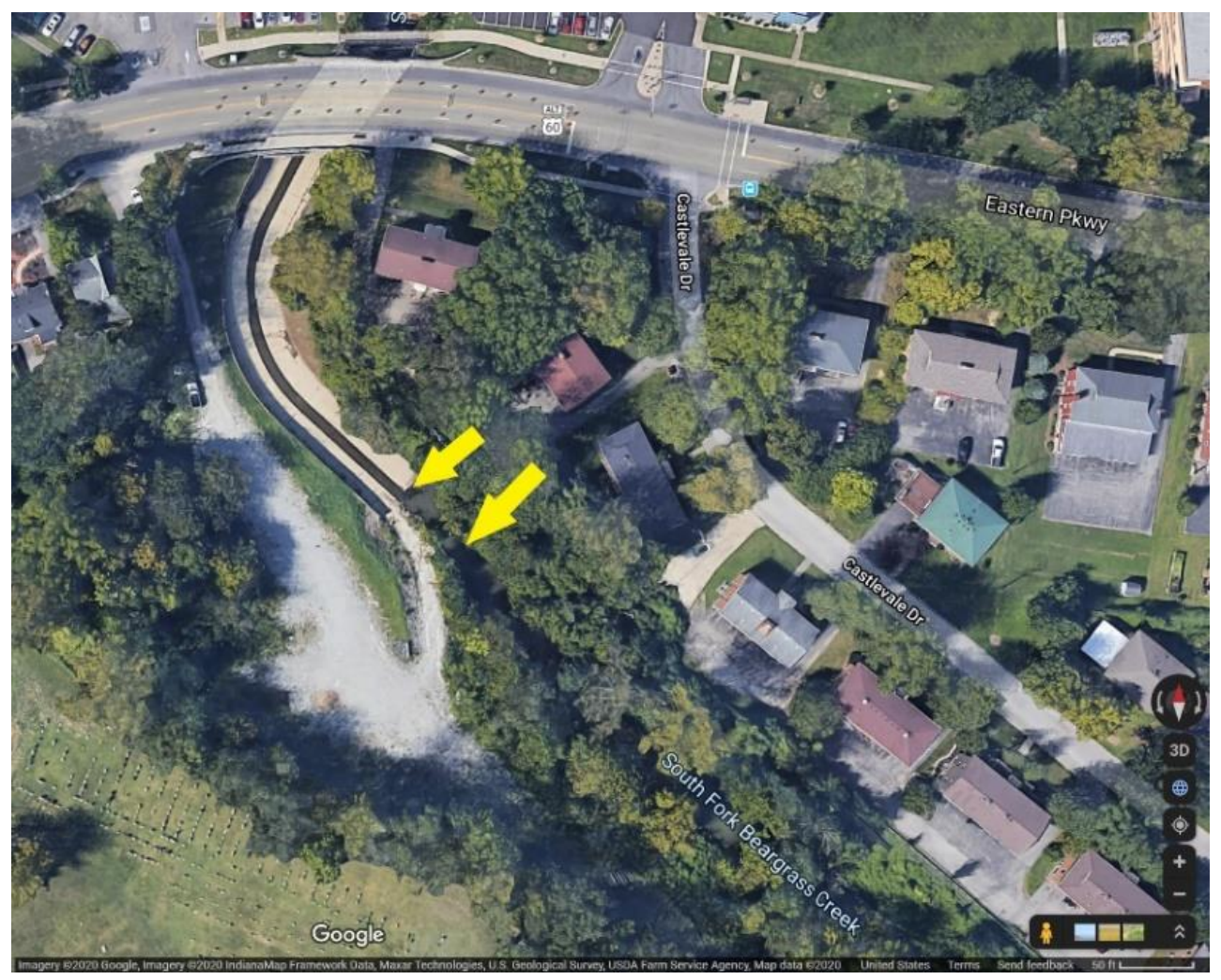

Figure 4.1 South Fork Beargrass Creek Sampling locations- Satellite image

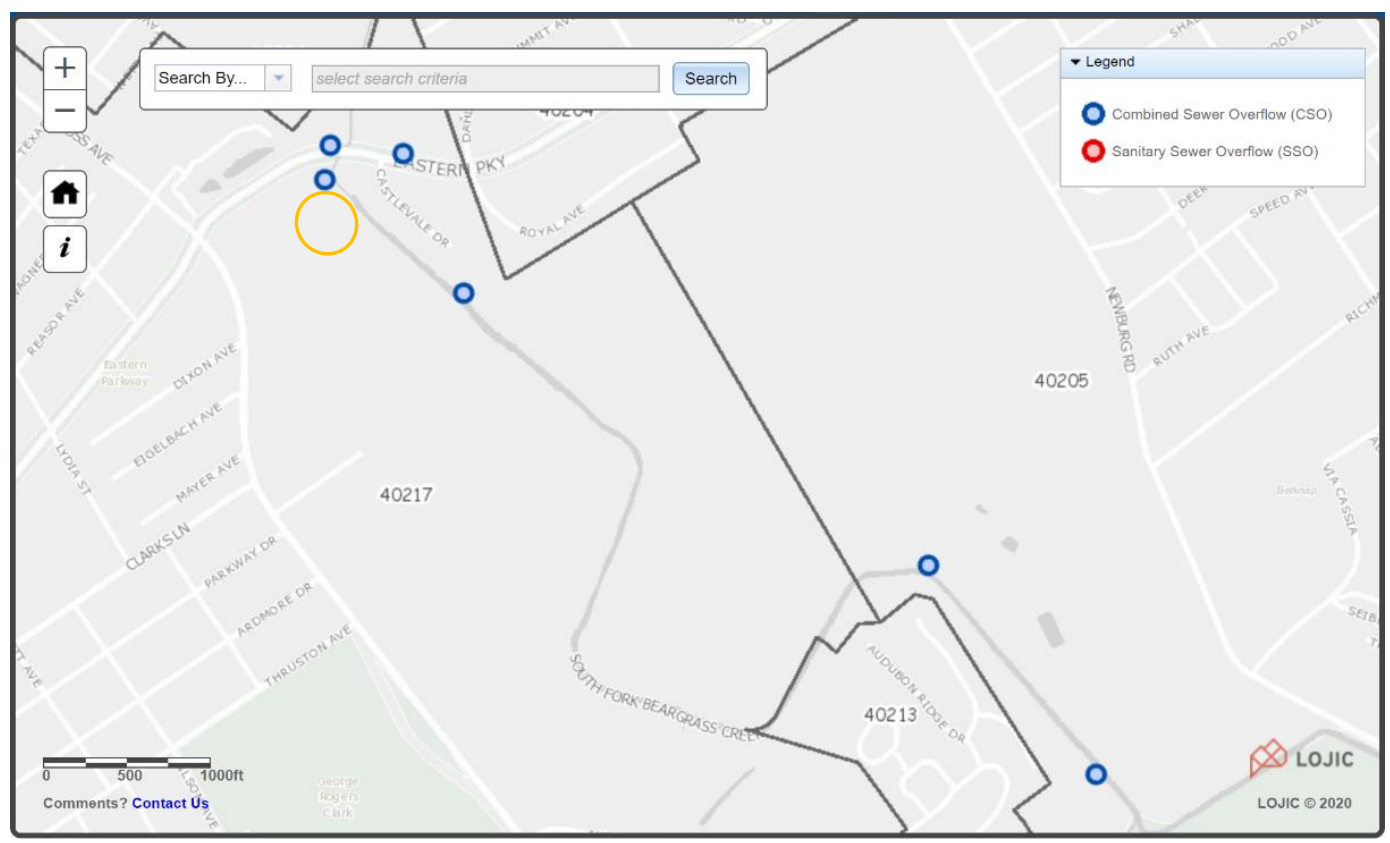

Figure 4.2 South Fork of Beargrass Creek MSD Map of CSO/SSO Locations with Sampling Location Circled in Orange (MSD, 2020) 


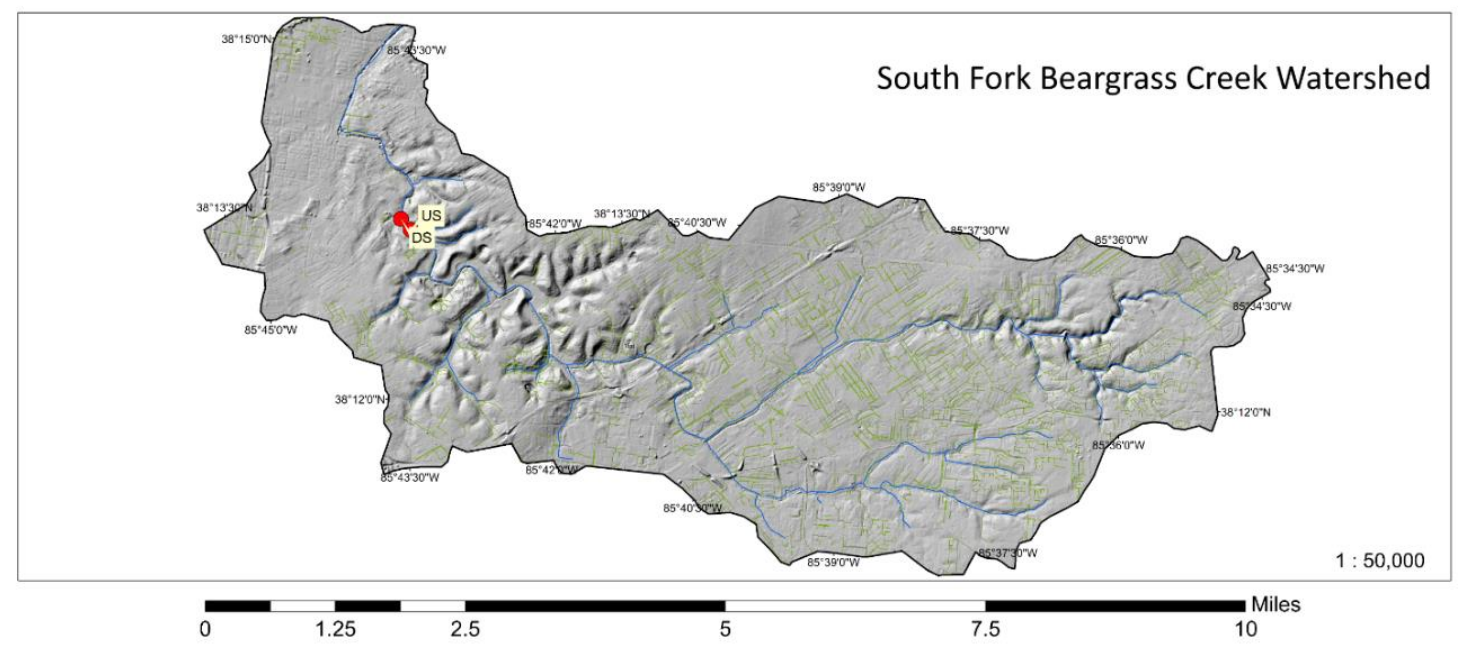

Figure 4.3 South Fork of Beargrass Creek Watershed with upstream (us) and downstream (ds) sampling locations

\subsubsection{Wilson Creek}

The control creek for the BACI research method was Wilson Creek located in Nelson County, KY. This creek was located deep within the center of Bernheim Forest, away from suburban housing and urban areas, necessitating walking through the forest to the sampling location because of the lack of any path suitable for driving and heavy vegetation. This creek was chosen because it was not located in an urban watershed, along with the past restoration jobs completed on parts of this creek to improve the quality of the creek and the riparian vegetation around. The ecological restoration completed by scientists at the University of Kentucky yielded positive results for the aquatic habitat (Drayer, 2017). A quote from the research publication described the outcome: 
"Overall, water and soil quality improved over time at the restoration site, while tree survival and height growth exhibited species-specific outcomes" (Drayer, 2017).

This location differed from Beargrass Creek sampling location because it was heavily wooded around the creek and the stream bed consisted of smooth rocks and sediment, whereas Beargrass Creek was a concrete channel. Figure 4.4 shows the geographic location of Wilson Creek. Figure 4.5 is an aerial photo of the sampling locations with the top arrow indicating upstream and the bottom arrow downstream.

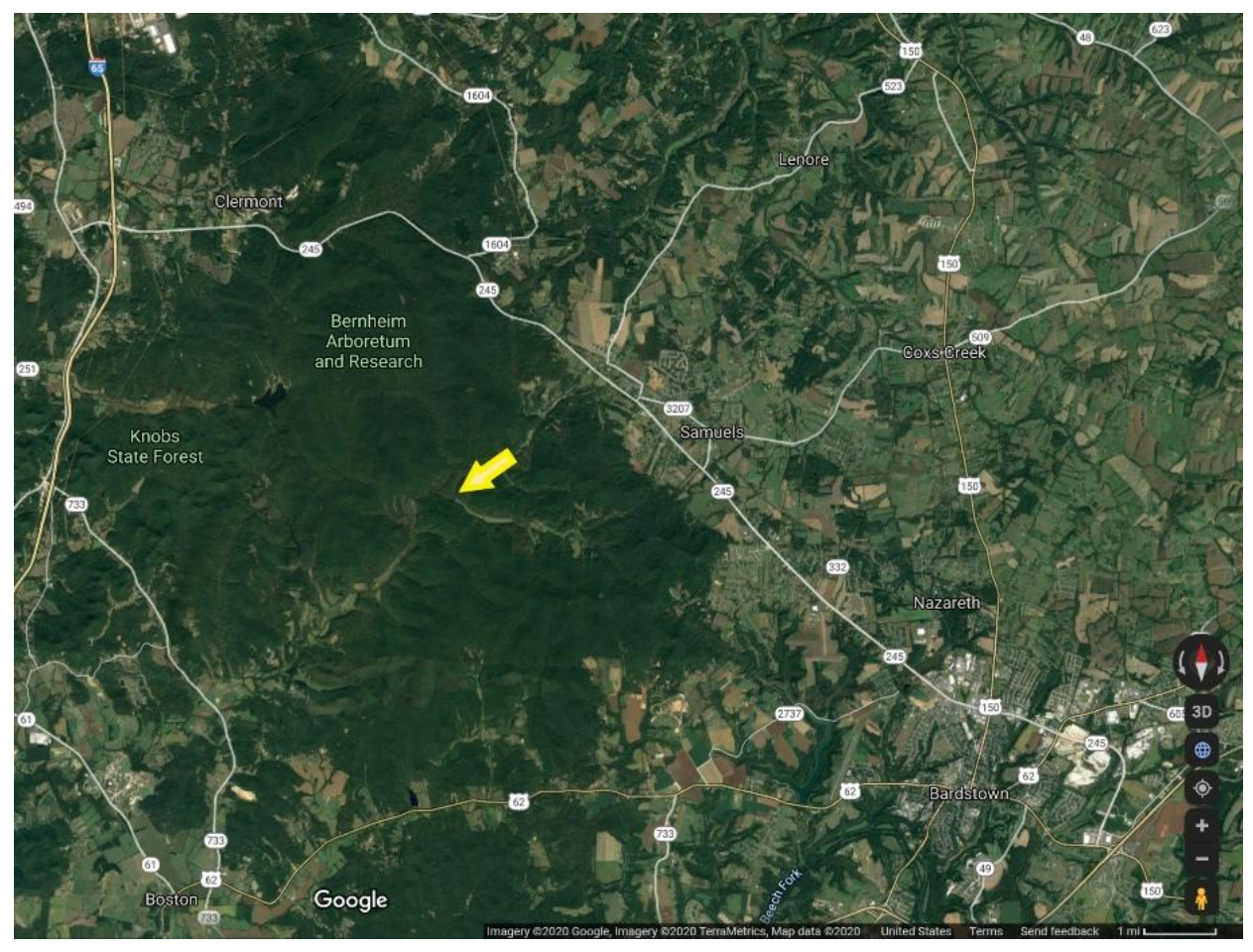

Figure 4.4 Location of Wilson Creek 


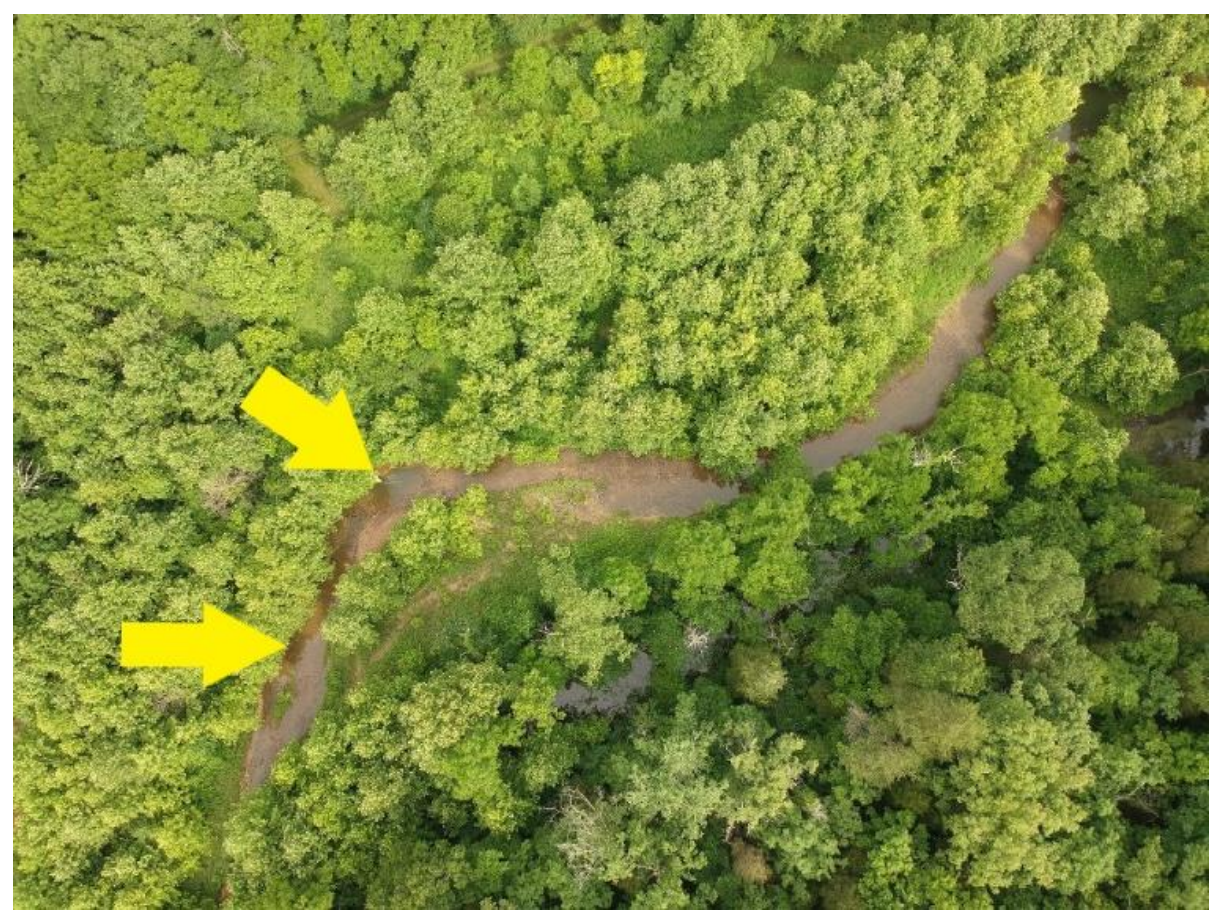

Figure 4.5 Wilson Creek in Bernheim Forest Sampling Locations 


\subsubsection{Mill Creek}

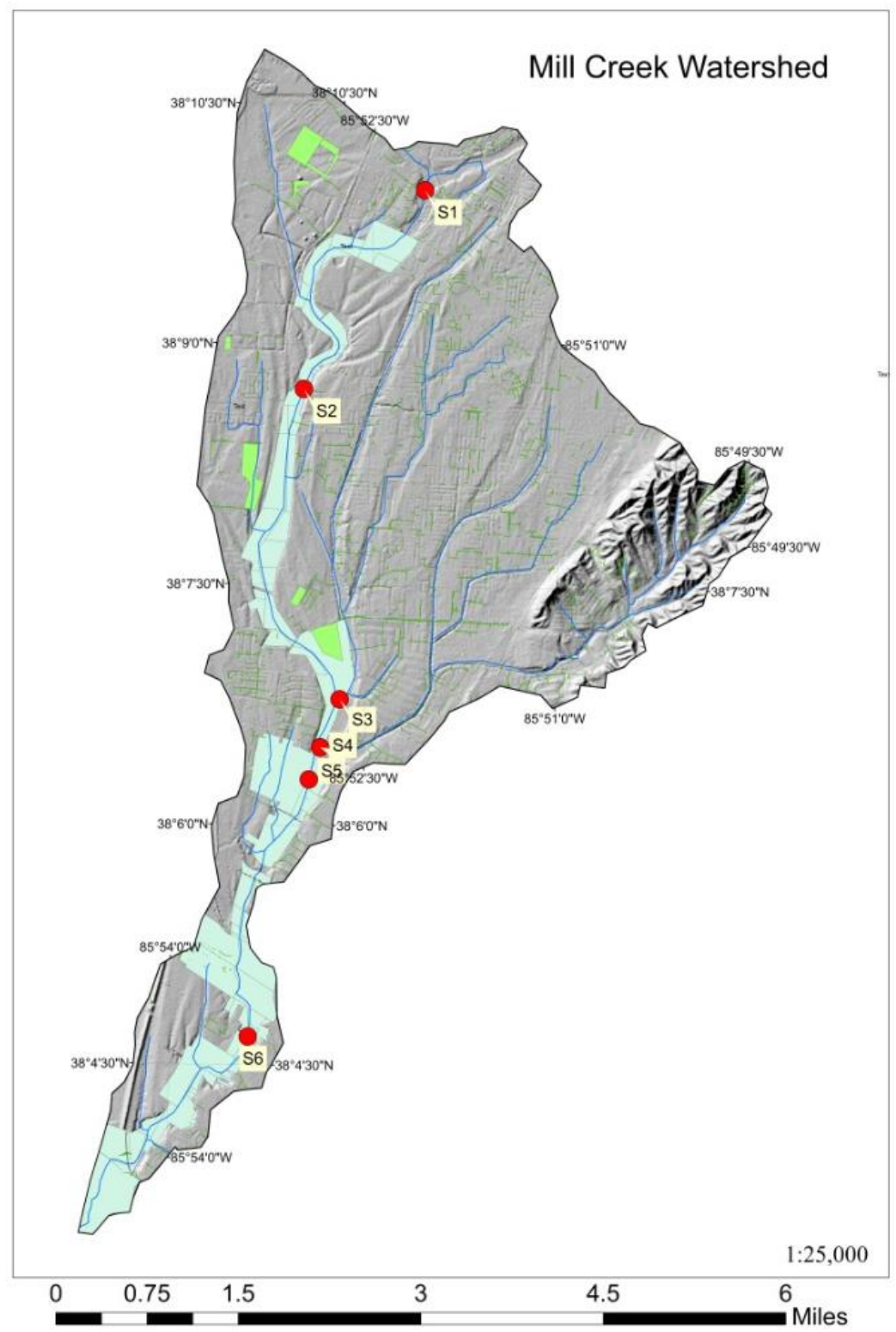

Figure 4.6 Mill Creek Sampling Locations within Watershed

The urban stream studied for the impact analysis was Mill Creek in Louisville,

KY. This stream had 6 locations chosen for sampling. Each location was numbered from 1 to 6 , with 1 being the furthest north upstream and 6 being the furthest south 
downstream. Figure 4.6 is a map of the six locations along Mill Creek. Each sampling location along the creek had unique details as discussed below.

1. Lower Hunters Trace: This location was where the creek began. There was a wetland below a road bridge with pooled water that was inhabited by frogs, small fish, and insects. High algae and high turbidity were common here. There were a combination of businesses and residential housing around the creek.

2. Greenwood Drive: This location was downstream of the Greenwood drive road bridge. Waters flowed consistently here, but had high turbidity and high algae, as well as notable populations of turtles present. There was only residential housing in a small section of the creek on the bank.

3. Black Pond Creek confluence: There was a distinct water color difference at this location where these two creeks met. The waters here were pooled with high turbidity and had visible algae floating on the water. Land use in this area seemed to be heavily forested, but through the forest there were a few houses located within. This site was the furthest site from any roads at about 0.25 miles from the nearest one.

4. Ashby Lane Confluence: Algae presence was highest at this confluence. This location had a large concrete divider at the confluence and was upstream of a road bridge. These waters had low turbidity and was pooled. This area also had residential housing adjacent.

5. Bethany Lane: This section of Mill Creek was near a golf course with a firehouse next to it. The water had low turbidity and was rapid through these parts. The depth of the creek was also low here. This section was also located under a 
driving and a walking bridge, which provided coverage to the population of snakes that resided there.

6. W Orell Road: This site was the furthest south downstream. Residential housing and businesses were on both sides of the creek, but a short distance from the sampling location. The sampling position was located in a valley beneath a driving bridge with large amounts of vegetation covering the creek. The water here was a rapid with low turbidity.

\subsection{Water Quality Tests}

Testing was conducted 2-3 times a week to complete at least five tests for e. coli concentrations within a 30-day period for each site in two different months per the KAR standard on e. coli testing. For control and impacted sites, June and July were the months for testing. For the study stream (Mill Creek sites) July and August were the months when testing took place. All testing was completed at dawn when the dissolved oxygen and $\mathrm{pH}$ was the lowest (Miranda, 2001). The sites on Mill Creek were visited in a random order each time. The biological lab tests were conducted in the order collected. While e. coli samples were taken every visit, the $\mathrm{DO}, \mathrm{pH}$, water temperature, and conductivity were only taken every other visit as the SRWW only required three tests to be completed in a year for assessment of a habitat. Therefore, for each site at least three tests were completed during the testing period. Tables 4.1 and 4.2 outline the 2019 testing schedule with testing dates bolded and underlined. 
Table 4.1 Calendar of Summer 2019 Testing of Control and Impacted Stream

\begin{tabular}{|c|c|c|c|c|c|c|}
\hline \multicolumn{7}{|c|}{ Beargrass Creek/ Wilson Creek Testing Days } \\
\hline \multicolumn{7}{|c|}{ June 2019} \\
\hline Sunday & Monday & Tuesday & Wednesday & Thursday & Friday & Saturday \\
\hline & & & $\underline{19}$ & 20 & 21 & $\underline{22}$ \\
\hline 23 & $\underline{24}$ & 25 & $\underline{26}$ & 27 & $\underline{28}$ & 29 \\
\hline 30 & & & & & & \\
\hline \multicolumn{7}{|c|}{ July 2019} \\
\hline Sunday & Monday & Tuesday & Wednesday & Thursday & Friday & Saturday \\
\hline & $\underline{1}$ & 2 & $\underline{3}$ & 4 & 5 & 6 \\
\hline 7 & $\underline{8}$ & 9 & $\underline{10}$ & 11 & $\underline{12}$ & 13 \\
\hline 14 & 15 & & & & & \\
\hline
\end{tabular}

Table 4.2 Calendar of Summer 2019 Testing of Mill Creek

\begin{tabular}{|c|c|c|c|c|c|c|}
\hline \multicolumn{7}{|c|}{ Mill Creek Testing Days } \\
\hline \multicolumn{7}{|c|}{ July 2019} \\
\hline Sunday & Monday & Tuesday & Wednesday & Thursday & Friday & Saturday \\
\hline & & & 17 & 18 & 19 & 20 \\
\hline 21 & $\underline{22}$ & 23 & 24 & 25 & 26 & $\underline{27}$ \\
\hline 28 & 29 & $\underline{30}$ & $\underline{31}$ & & & \\
\hline \multicolumn{7}{|c|}{ August 2019} \\
\hline Sunday & Monday & Tuesday & Wednesday & Thursday & Friday & Saturday \\
\hline & & & & 1 & $\underline{2}$ & 3 \\
\hline 4 & $\underline{5}$ & 6 & $\underline{7}$ & 8 & 9 & $\underline{10}$ \\
\hline 11 & 12 & 13 & 14 & 15 & 16 & $\underline{17}$ \\
\hline
\end{tabular}

\subsubsection{Hach® Wide Range Indicator pH Kit (Model 17-N)}

The Hach ${ }^{\circledR}$ Wide Range Indicator $\mathrm{pH}$ kit was used for field sampling of the $\mathrm{pH}$ of the creeks. This test kit was acquired after field training from professionals with USGS on field sampling. The test kit came complete with a color disc, $\mathrm{pH}$ indicator solution, and two test tubes. The $\mathrm{pH}$ value of a water sample was found using two tubes filled with $5 \mathrm{~mL}$ of water from the creek. One tube was then mixed with 6 drops of the indicator reagent. The indicator solution changed the waters color based on the hydrogen ions within to indicate the $\mathrm{pH}$. The tube with the solution was compared to the tube with the 
unchanged sample water against a color wheel to determine the $\mathrm{pH}$. The range of $\mathrm{pH}$ that this test could provide was between 4 and 10 .

\section{Important pH Factors}

For recreational waters, the $401 \mathrm{KAR}$ on surface water quality states that the $\mathrm{pH}$ shall be between 6 and 9 and will not change more than 1 standard unit per 24-hour period. Fluctuations in $\mathrm{pH}$ can become stressful for fish and organisms within the water leading to fish kills (Allan, 2007). If the $\mathrm{pH}$ becomes too low $(<6)$, the acidity of the water will make heavy metals more soluble causing organisms to absorb these toxic materials (pH, 2002). Low pH can also erode piping infrastructure as well (pH, 2002). High $\mathrm{pH}(>9)$ is not lethal, but basic water can cause deposits in piping to build up, odors, and bitter tastes ( $\mathrm{pH}, 2002)$. The causes of these changes can come from multiple sources in a watershed. Rain is considered acidic ( $\mathrm{pH}$ of 5.5), so this can add to the acidity of a stream (pH, 2002). Fertilizer or mining drainage in run off can also cause a change in acidity (Allan, 2007). Photosynthesis from aquatic plants can increase the $\mathrm{pH}$ by converting carbon dioxide $\left(\mathrm{CO}_{2}\right)$ in the water into oxygen $\left(\mathrm{O}_{2}\right)$ utilizing solar radiation. If the carbon dioxide in the water is not used in photosynthesis, it can react with water $\left(\mathrm{H}_{2} \mathrm{O}\right)$ to create bicarbonate $\left(\mathrm{HCO}_{3}{ }^{-}\right)$and hydrogen ions $\left(\mathrm{H}^{+}\right)$, therefore decreasing the $\mathrm{pH}$ (Allan, 2007).

$$
\mathrm{CO}_{2}+\mathrm{H}_{2} \mathrm{O} \rightarrow \mathrm{HCO}_{3}^{-}+\mathrm{H}^{+}
$$

These impacts can be reduced using a buffer. In Kentucky, there are large amounts of limestone located in the state that act as a calcium carbonate buffer to neutralize the waters to a pH of 7 (Córdoba, 2017). 


\subsubsection{Winkler Dissolved Oxygen Test}

Compared to the other field tests of this project, dissolved oxygen concentration test involved the most steps to complete. Using several chemical reactions, this test was used to determine the parts per million ( $\mathrm{ppm}$ ) of oxygen molecules available in a sample of creek water. According to the LaMotte Dissolved Oxygen Water Quality Test Kit Instruction Manual (Code 5860-01), the "Short Form Instructions" are:

1. Fill Water Sampling Bottle (0688-DO).

2. Add 8 drops of *Manganous Sulfate Solution (4167).

3. Add 8 drops of *Alkaline Potassium Iodide Azide (7166).

4. Cap and mix.

5. Allow precipitate to settle.

6. Add 8 drops of Sulfuric Acid, 1:1 (6141WT).

7. Cap and mix until reagent and precipitate dissolve.

8. Fill test tube (0608) to the $20 \mathrm{~mL}$ line.

9. Fill Titrator with *Sodium Thiosulfate, $0.025 \mathrm{~N}$ (4169).

10. Titrate until sample color is pale yellow. DO NOT DISTURB TITRATOR.

11. Add 8 drops of Starch Indicator (4170WT).

12. Continue titration until blue color just disappears and solution is colorless. 


\section{Read result in ppm Dissolved Oxygen.}

This procedure was conducted with water collected from a depth halfway to the bottom of the water column per KAR 401 for surface water quality standards. The sampling bottle had to be submerged with no bubbles within and vertically oriented when capped.

\section{$\underline{\text { Important Dissolved Oxygen Factors }}$}

DO needs to be at least $5 \mathrm{mg} / \mathrm{L}$ (equivalent to $5 \mathrm{ppm}$ ) in a 24-hour period and the instantaneous DO concentration must not reach below $4 \mathrm{mg} / \mathrm{L}$ at any time for Kentucky surface water standards. $5 \mathrm{ppm}$ is the concentration where aquatic habitats can sustain fish populations; Less than that and the fish population struggle to survive (Allan, 2007). Dissolved oxygen has two main sources: the atmosphere and photosynthesis from aquatic plants and phytoplankton (Allan, 2007). Atmospheric oxygen can be captured from contact of the surface of the water or by motion sequestering the oxygen through waves (Allan, 2007). In certain circumstances, engineers have proposed infrastructure for causing disruption in a stream flow, for example steps in the water, to reoxygenate the water.

Photosynthesis through aquatic plants and phytoplankton is another component of the oxygen concentration of a water body. Photosynthesis requires carbon dioxide and solar radiation in order for plants to produce glucose and oxygen.

$$
\text { Solar Radiation }+6 \mathrm{CO}_{2}+6 \mathrm{H}_{2} \mathrm{O} \rightarrow \mathrm{C}_{6} \mathrm{H}_{12} \mathrm{O}_{6}+6 \mathrm{O}_{2}
$$

The use of solar radiation changes the oxygen produced and used throughout a day. When the sun rises, plants begin to produce oxygen, meaning the dissolved oxygen concentration is at its lowest levels at dawn (Allan, 2007). As the day progresses, the 
oxygen will increase until species become active and begin to consume the oxygen produced, causing it to reduce again. Once the sun sets, the oxygen will reduce to low levels, again. Figure 4.7 illustrates these changes in dissolved oxygen concentrations of a stream throughout a day.

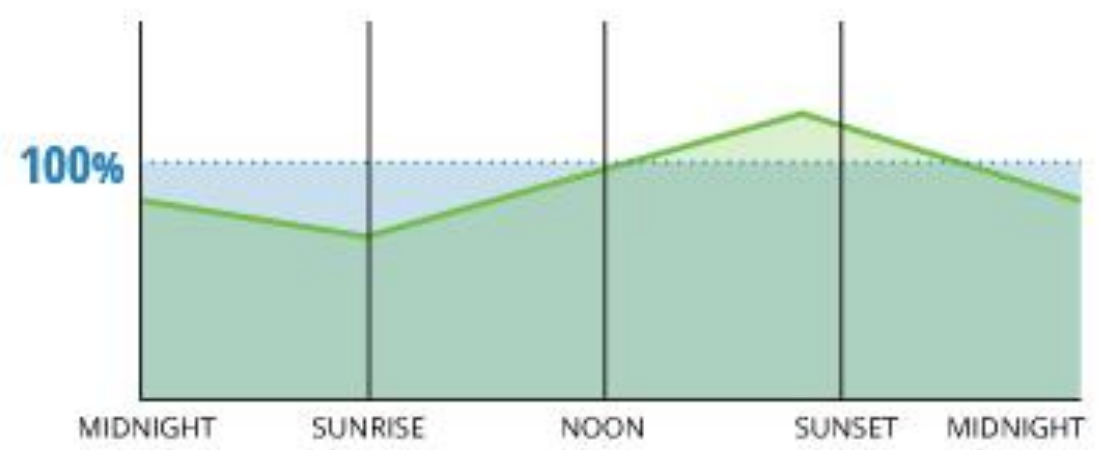

Figure 4.7 Dissolved Oxygen concentrations in a stream over one day (Fondriest, 2019)

\subsubsection{Water Temperature}

The water temperature involved the least amount of steps for field testing compared to other tests completed. The temperature was recorded from a mercury thermometer in degrees Celsius $\left({ }^{\circ} \mathrm{C}\right)$. The method used involves leaving the thermometer submerged in the water at the same depth samples were taken. This depth was about halfway to the bottom in shallow waters and 0.5 meters down in deeper sections. The time submerged was 1 minute before reading the value.

\section{Important Water Temperature Factors}

The climate of a region will alter the temperature of the water flowing through there. Changes to temperature are harmful for fish species who are adapted to a habitat 
and cannot survive in warmer waters. As mentioned in chapter 2, Urban Heat Island can cause a rise in water temperature, however water temperature changes are also seen in urban areas with industrial land use. Industries, such as power companies, discharge liquids used for cooling their systems into the creek. This water discharged will cause a spike in temperature and kill the fish or plants in the area. Maintaining a consistent temperature each season is important for inhabiting species to continue their survival.

The 401 KAR 10:031 for surface water standards states that the temperature of the water is not to exceed $31.7^{\circ} \mathrm{C}$. The standard also states that temperatures should not fluctuate from seasonal expected changes. Table 4.3 below indicates where the water temperature of Kentucky waters should average each month and maximum values.

Table 4.3 401 KAR 10:031 Surface Water Standards for Water Temperature Average and Instantaneous Maximums

\begin{tabular}{|l|l|l|l|l|}
\hline \multirow{2}{*}{ Month/Date } & \multicolumn{3}{|l|}{ Period Average } & \multicolumn{2}{l|}{$\begin{array}{l}\text { Instantaneous } \\
\text { Maximum }\end{array}$} \\
\cline { 2 - 5 } & $\left({ }^{\circ} \mathrm{F}\right)$ & $\left({ }^{\circ} \mathrm{C}\right)$ & $\left({ }^{\circ} \mathrm{F}\right)$ & $\left({ }^{\circ} \mathrm{C}\right)$ \\
\hline January 1-31 & 45 & 7 & 50 & 10 \\
\hline February 1-29 & 45 & 7 & 50 & 10 \\
\hline March 1-15 & 51 & 11 & 56 & 13 \\
\hline March 16-31 & 54 & 12 & 59 & 15 \\
\hline April 1-15 & 58 & 14 & 64 & 18 \\
\hline April 16-30 & 64 & 18 & 69 & 21 \\
\hline May 1-15 & 68 & 20 & 73 & 23 \\
\hline May 16-31 & 75 & 24 & 80 & 27 \\
\hline June 1-15 & 80 & 27 & 85 & 29 \\
\hline June 16-30 & 83 & 28 & 87 & 31 \\
\hline July 1-31 & 84 & 29 & 89 & 32 \\
\hline August 1-31 & 84 & 29 & 89 & 32 \\
\hline September 1-15 & 84 & 29 & 87 & 31 \\
\hline September 16-30 & 82 & 28 & 86 & 30 \\
\hline October 1-15 & 77 & 25 & 82 & 28 \\
\hline October 16-31 & 72 & 22 & 77 & 25 \\
\hline November 1-30 & 67 & 19 & 72 & 22 \\
\hline December 1-31 & 52 & 11 & 57 & 14 \\
\hline
\end{tabular}


Rises in temperature have an effect on the oxygen concentration in the water. Dissolved oxygen is lower in concentration in warmer waters because of the faster speeds of the excited molecules of water that allow oxygen to escape (Allan, 2007). In colder water, the molecules are slower allowing for more of a concentration of oxygen in the water (Allan, 2007). Figure 4.8 below shows the effect of temperature on the DO concentration in a river.

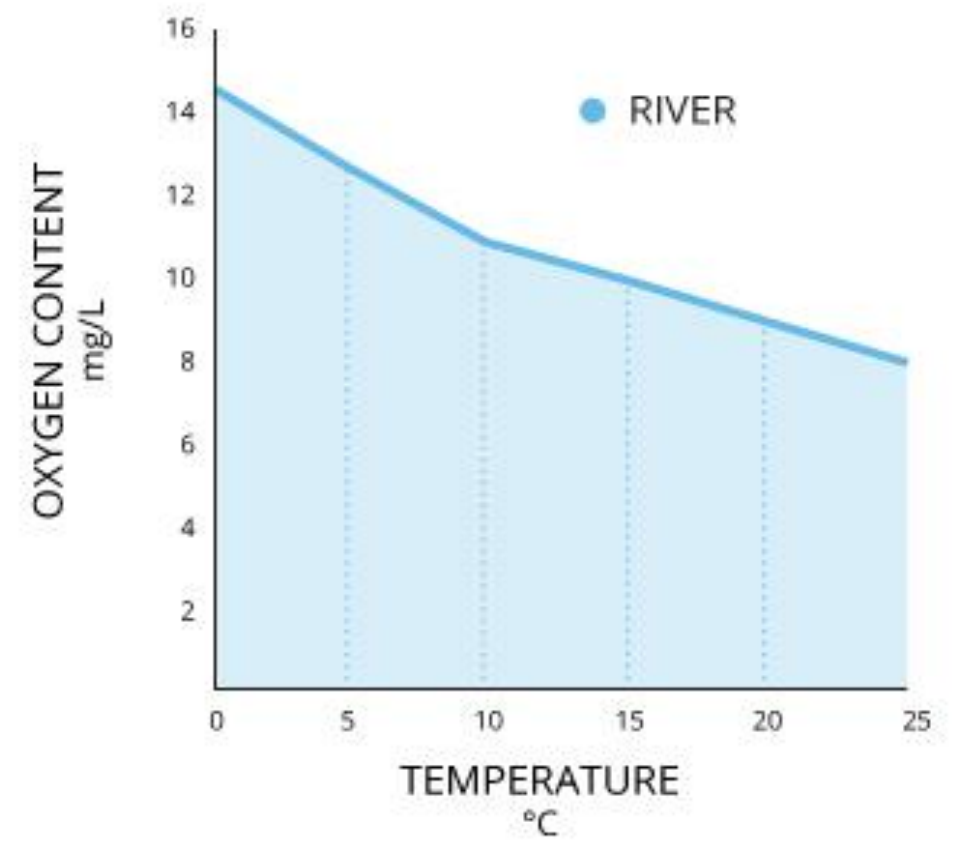

Figure 4.8 Dissolved Oxygen Concentration vs Temperature in a river system (Fondriest, 2019)

\subsubsection{Conductivity}

Conductivity was a measurement taken in the field. The equipment used was a Oakton EcoTestr EC Low pocket conductivity tester. This device required calibration with a standard solution before use. The method was simply turning on the meter and then placing the uncovered prongs into the sample site water until the meter value 
stopped changing. As the meter was in the water, it emitted an electric current from the prongs to quantify the conductivity of the water. The meter ranged from 0 to 1990 micro Siemens per centimeter $(\mu \mathrm{S} / \mathrm{cm})$. The units were micro Siemens because these are units for electric conductance (5.9 Conductivity, 2012).

\section{$\underline{\text { Important Conductivity Factors }}$}

Conductivity is affected primarily by the presence of organic and inorganic compounds to allow electric currents to flow through (5.9 Conductivity, 2012). Therefore, pollutants discharging into a stream from point source or nonpoint source locations can alter conductivity values. An example is a combined sewer overflow discharging wastewater into a river will increase the value of conductivity due to the presence of "chloride, phosphate, and nitrate" (5.9 Conductivity, 2012). Warmer waters will also have higher conductivity.

The rivers in the Unites States range in conductivity. Expected range for a U.S. river would be anywhere from $50-1500 \mu \mathrm{S} / \mathrm{cm}$. A healthy habitat for a diverse population of fish would require a conductivity around 150 to $500 \mu \mathrm{S} / \mathrm{cm}$ (5.9 Conductivity, 2012). The 401 KAR 10:031 Surface Water Standards does not have a specific value for their surface water standard, but does state:

"Total dissolved solids or specific conductance shall not be changed to the extent that the indigenous aquatic community is adversely affected".

Therefore, the range for conductance was determined to be a wide range of suitability, as long as organisms populations were present. 


\subsubsection{Membrane Filtration Escherichia Coli Concentration Test (Method 1604)}

The Membrane Filtration Test was used for calculating the e. coli concentration of the water sampled. This test is approved by the EPA for determining total coliform and e. coli concentration per $100 \mathrm{~mL}$ of sample. Using a membrane filtration required a variety of equipment, conscious behavior, and strategic planning to ensure sampled water was viable to be tested.

This test was completed in the Deborah Yoder-Himes Biology Laboratory at the University of Louisville. This lab provided items for the apparatus that contained the filtration. A diagram of the filtering apparatus is in figure 4.9 below. The apparatus parts used were a filtering cup to funnel the sample water through the filter head. The filter head had a piece of sterile $47 \mathrm{~mm}$ filter membrane on top of it for the sample water to filter through. When the water went through the membrane the e. coli colonies would remain on the filter paper because they are too large for the $0.45 \mu \mathrm{m}$ pores. These pieces were held by a clamp to a conical flask to store the wastewater of the filtration. The flask also came equipped with an outlet to attach a rubber hose to the vacuum spout in the lab to create a vacuum within the apparatus. 


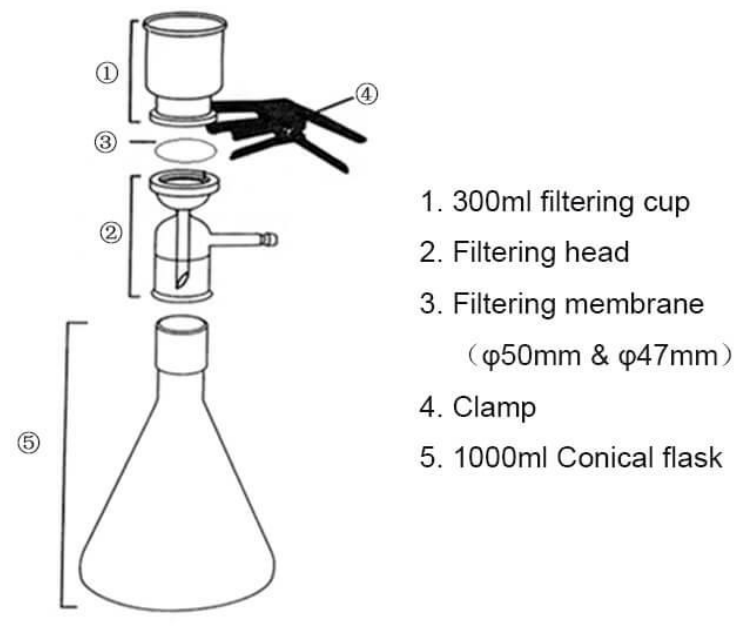

Figure 4.9 Filtration Apparatus Diagram (toptionlab.com, 2020)

The samples that were collected for this device were obtained using brown sterile bottles. These bottles had to be sterilized after each use by hand washing and heat from an autoclave. The bottles remained capped until submerged and then the bottle was filled with creek sample. The order of sites was random each trip and samples were tested in this random order. The samples were stored in a cooler with ice packs to remain cool until arrival to the lab (Oshiro, 2002). Samples were only valid for 6 hours after collection if stored properly (Oshiro, 2002).

Once the samples arrived in the lab, the filtration occurred. The samples were diluted using distilled water (1:10 for Mill Creek and Wilson Creek, 1:20 for Beargrass Creek) to increase the ability to read the results. For a sample that needed to be diluted, the formula provided by the EPA to discover the concentration per $100 \mathrm{~mL}$ of sample was:

E. Coli/ $100 \mathrm{~mL}=\frac{\text { Number of Blue Colonies }}{\text { volume of sample filtered }(\mathrm{mL})} * 100$ 
Once the samples were diluted and filtered through the vacuumed sterile filter membrane, the funnel was unclamped to remove the funnel cup. Once removed, the filter membrane could be removed and place on the MI agar medium at room temperature. MI agar is a "chromogenic/fluorogenic medium" (Oshiro, 2002). The reason the filter membrane with the e. coli colonies were placed on this medium was because it contained enzymes that allowed the colonies to survive, but not grow. The MI agar used in this experiment was Difco ${ }^{\mathrm{TM}}$ MI Agar, which contained a variety of ingredients including yeast extract and required an antibiotic to be used to ensure no outside contamination of the mediums. Another useful property was of the medium was that it caused the e. coli colonies to appear as blue when the membrane was placed on it after filtration. This color contrast of blue colonies on the tan medium allowed for easy counting. The colonies would only change into this blue shade 24 hours after filtration when left in an incubation. For this study, an incubation room was used at $35^{\circ} \mathrm{C}$. The results were petri dishes with blue colonies scattered throughout that could be counted before properly being disposed of. All equipment was washed and sterilized after each membrane filtration. Figures $4.10 \mathrm{a}$, $\mathrm{b}$, and $\mathrm{c}$ below are a few examples of the results. 


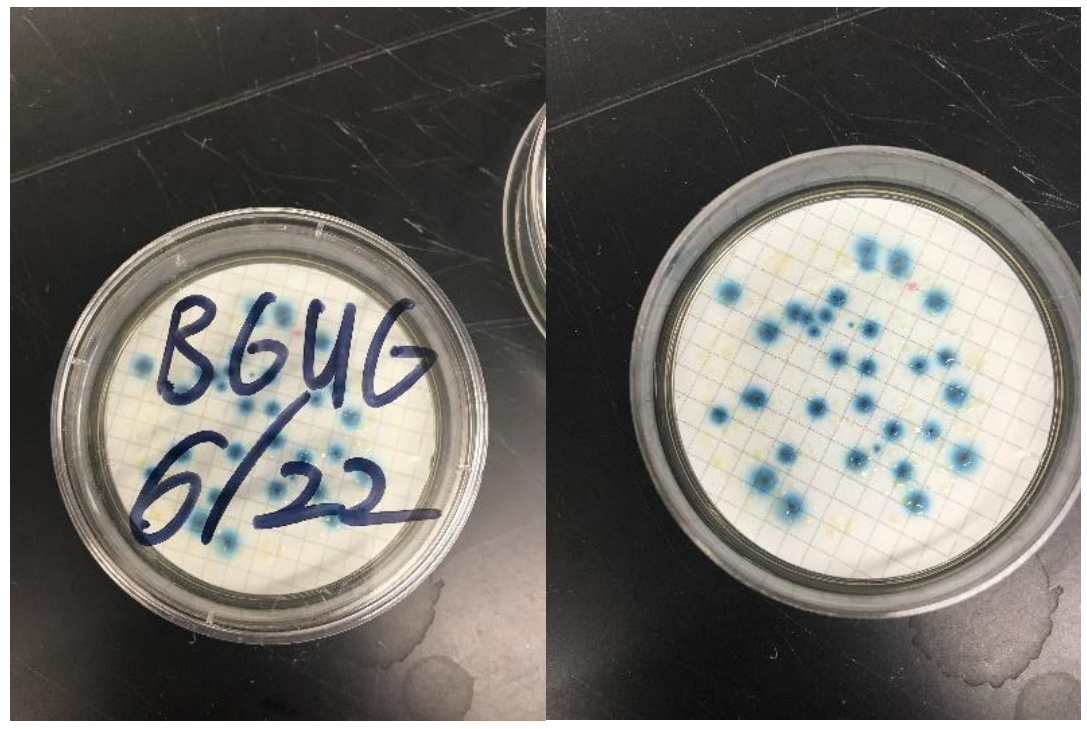

Figure 4.10 (a) Beargrass Creek Upstream Grab sample (BGUG) example results $(6 / 22 / 19)$

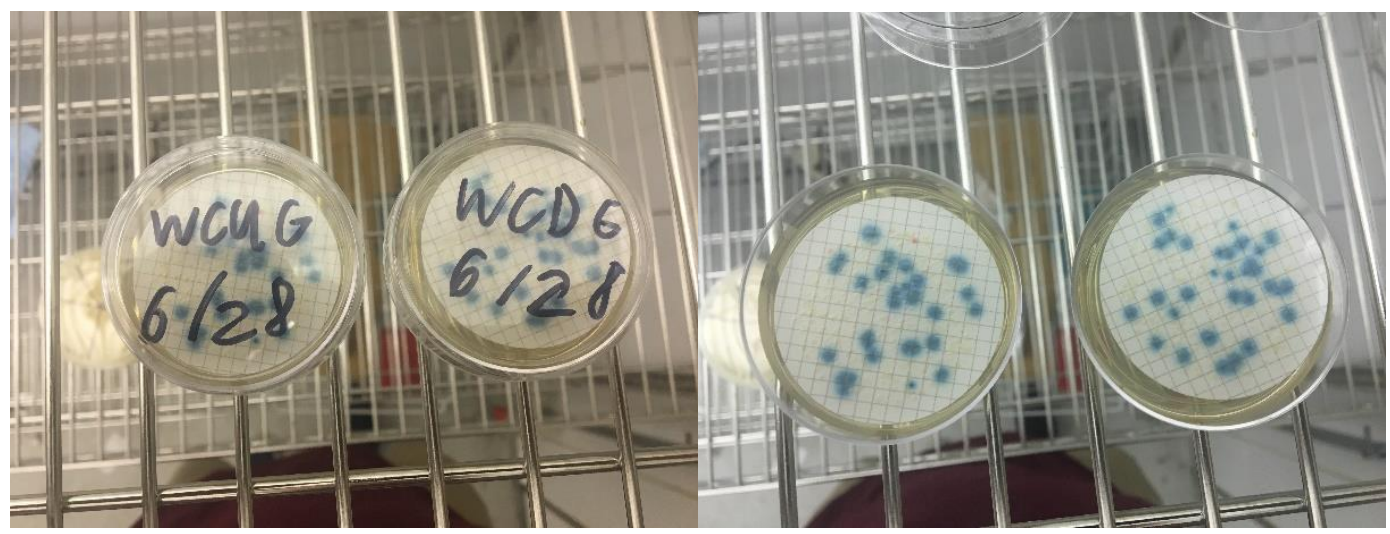

Figure 4.10 (b) Wilson Creek Upstream \& Downstream Grab sample example results $(6 / 28 / 19)$ 


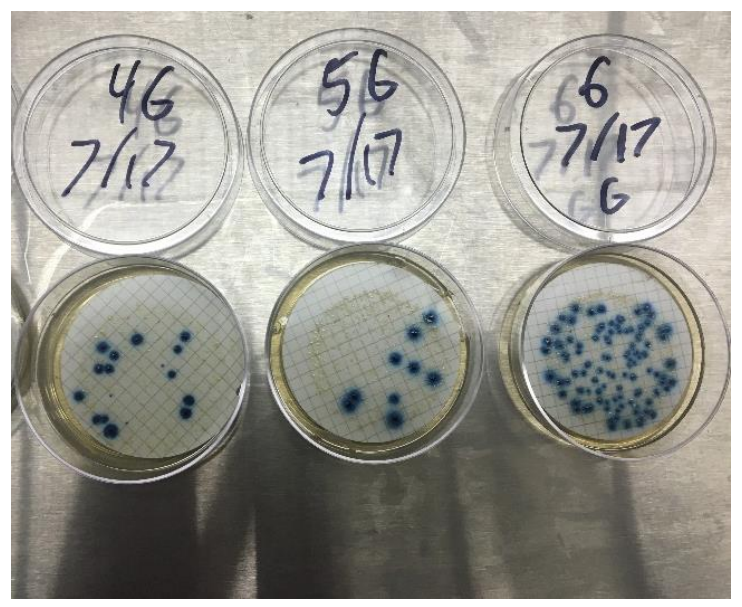

Figure 4.10 (c) Mill Creek example grab (G) sample results for sites 4, 5, 6 (7/17/19)

\section{$\underline{\text { Important E. Coli Concentration Factors }}$}

E. coli is treated as an indicator bacteria to warn water monitoring services of fecal contamination within a water source. The Kentucky Energy and Environment Cabinet has set limits on the concentrations allowable of these bacteria in the 401 KAR. The maximum e. coli concentration in Kentucky recreational waters in 130 colonies per $100 \mathrm{~mL}$ of sample as a geometric mean of five samples taken in a 30 day period. This project did two 30 day periods with two sets of at least five samples at each site. The concentration of e. coli should not exceed 240 colonies per $100 \mathrm{~mL}$ sample in over $20 \%$ of the samples taken.

E. coli bacteria originates in the large intestine of warm blooded animals. Therefore, the main mode of transmission for the bacteria to a water body is excrement through wastewater. The growth of e. coli is maximized when conditions in the environment mimic that of a warm-blooded mammals organ system, for instance, when the temperature is above $36^{\circ} \mathrm{C}$. Therefore, the climate of the region will need to be recorded for the area to identify factors impacting the e. coli growth. 
The main source studies have found that an increase of e. coli

concentration occurs is whenever there are occurrences of rainfall (Miller, 2017). This leads to runoff events where more pollutants are discharging into the river from surface runoff or system overflows. These conditions are found to produce harmful algal blooms (HAB) from eutrophication, as well. Therefore, many harmful algal blooms occur simultaneously with high concentrations of e. coli (Englebert, 2008). These blooms require solar energy (heat) and rainfall events to discharge pollutants into the water. HABs require large amounts of nitrogen and phosphorous as nutrients from the runoff, but the e. coli can utilize these nutrients for growth, as well (Englebert, 2008). Under conditions of urbanization with the climate of the region, these two occurrences will be occur more frequently, leading many scientists to believe that e. coli concentrations and HABs will increase in the future as urban sprawl continues (Englebert, 2008) (JalliffierVerne, 2017). 


\section{CHAPTER 5}

\section{RESULTS}

\subsection{Introduction}

This section will discuss the environmental and hydrologic factors pertaining to each creek that impacted the water quality. The section will be followed by a presentation of the results of the parameters tests conducted in Central Kentucky streams during the Summer of 2019. The data used to understand the climate in the region pertains to precipitation and atmospheric temperatures. The National Oceanic and Atmospheric Administration (NOAA) maintains an extensive database containing this information that will be utilized for this section of the study. The tests conducted for water quality were dissolved oxygen (DO), conductivity, $\mathrm{pH}$, water temperature, and e. coli concentration per $100 \mathrm{~mL}$ of sample.

\subsection{Environmental and Hydrologic Factors}

The environment that surrounds the urban streams in this study is Louisville, KY, the $29^{\text {th }}$ largest city in the United States (U.S. Census, 2019). Louisville, KY is an expanding metropolitan area with a demand for urban growth as the population continues to grow. In 2000, the population of Louisville was 256,231 people, then grew $133 \%$ in 2010 to 597,337 people (U.S. Census, 2019). During the testing period of this project, the population was estimated to have increased $3.4 \%$ to 617,638 people (U.S. Census, 2019). 
This growth in population indicates that the water quality is in risk of degradation from human impacts, such as waste discharge or runoff pollution, as described in section 2.

The increase in population is a precursor or urban sprawl, as well. The demand for more housing, like apartment buildings and suburbs, to accommodate this rising population will impact the quality of the water in urban settings. Along with housing infrastructure sprawling the city, Louisville has also been expanding its downtown sector with the recent addition of a luxury hotel and a new soccer stadium to attract tourism or new residents to the area. These all are forms of urbanization that continue to increase the urban area towards the boundary of Jefferson County as the population increases.

Climate is another environmental and hydrologic factor impacting this study of water quality in an urban stream. The climate data will be presented with the water quality tests results to indicate conditions on each sampling day. Overall trends in the climate data reveal 2019 to have higher average temperatures than the average temperature for this region of the country (NOAA, 2020). There were also higher volumes of precipitation for the year than on average (NOAA, 2020).

\subsection{Water Quality and Climate Data}

As stated in chapter 4, the impact study method used for this project required a control creek and an impacted creek to compare with the changes observed over time on Mill Creek. The data below will outline and analyze the results for each category of water quality for all creeks tested. This data will provide evidence that environmental and hydrologic factors, including urbanization, are causing degradation of the quality of the water in the urban stream. 


\section{Impacted- South Fork Beargrass Creek}

Beargrass Creek is an impacted creek causing municipal companies of Louisville to be concerned of the quality of the water. This creek is used for this experiment to indicate poor quality of water to compare with Mill Creek. This creek was tested during the same time period as Wilson Creek testing. Table 5.1 below shows the results of the Beargrass creek surface water quality tests. The dates in the table in blue indicate days with precipitation

Table 5.1 Beargrass Creek Results from Water Quality Tests and Climate Data

\begin{tabular}{|c|c|c|c|c|c|c|c|c|c|}
\hline \multirow{2}{*}{ Date } & \multirow{2}{*}{ Site } & \multirow{2}{*}{\begin{tabular}{|} 
Precipitation \\
(In.)
\end{tabular}} & \multicolumn{2}{|c|}{ Atm. Temp $\left({ }^{\circ} \mathrm{C}\right)$} & \multirow{2}{*}{$\begin{array}{c}\text { Dissolved } \\
\text { Oxygen (ppm) }\end{array}$} & \multirow{2}{*}{$\begin{array}{c}\text { Conductivity } \\
(\mu \mathrm{S} / \mathrm{cm})\end{array}$} & \multirow{2}{*}{$\mathrm{pH}(\mathrm{SU})$} & \multirow{2}{*}{$\begin{array}{c}\text { Water } \\
\text { Temp }\left({ }^{\circ} \mathrm{C}\right)\end{array}$} & \multirow{2}{*}{$\begin{array}{l}\text { E.coli concentration } \\
\text { per } 100 \mathrm{~mL} \text { of sample }\end{array}$} \\
\hline & & & High & Low & & & & & \\
\hline \multirow{2}{*}{$6 / 19 / 2019$} & Downstream & \multirow{2}{*}{1.32} & \multirow{2}{*}{27.2} & \multirow{2}{*}{21.1} & \multirow{2}{*}{6} & \multirow{2}{*}{500} & \multirow{2}{*}{7.5} & \multirow{2}{*}{20.8} & 1500 \\
\hline & Upstream & & & & & & & & 1440 \\
\hline \multirow{2}{*}{$6 / 22 / 2019$} & Downstream & \multirow{2}{*}{0.45} & \multirow{2}{*}{27.8} & \multirow{2}{*}{19.4} & \multirow{2}{*}{-} & \multirow{2}{*}{-} & \multirow{2}{*}{-} & \multirow{2}{*}{-} & 680 \\
\hline & Upstream & & & & & & & & 1160 \\
\hline \multirow{2}{*}{$6 / 24 / 2019$} & Downstream & \multirow{2}{*}{0.5} & \multirow{2}{*}{26.7} & \multirow{2}{*}{21.7} & \multirow{2}{*}{5.3} & \multirow{2}{*}{500} & \multirow{2}{*}{7.5} & 9 2 & 1900 \\
\hline & Upstream & & & & & & & 20.9 & 2240 \\
\hline & Downstream & 128 & 30 & 101 & 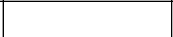 & 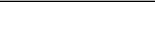 & 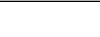 & 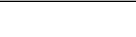 & 2560 \\
\hline$b / \angle b / \angle U 19$ & Upstream & 1.28 & 30 & 19.4 & - & - & - & - & 2460 \\
\hline $6 / 28 / 2010$ & Downstream & 0 & 328 & 211 & $5 ?$ & 180 & 75 & 248 & 660 \\
\hline $0 / \angle 8 / \angle 019$ & Upstream & 0 & 32.8 & 21.1 & 5.2 & 480 & 1.5 & 24.8 & 1500 \\
\hline $7 / 1 / 2019$ & Downstream & 033 & 339 & 233 & - & - & - & - & 2840 \\
\hline$/ / 1 /<019$ & Upstream & 0.35 & 35.9 & 23.3 & - & - & - & - & 2500 \\
\hline $7 / 3 / 2019$ & Downstream & 0 & 339 & 239 & 38 & 480 & 75 & 238 & 300 \\
\hline $1 / 0 / 2015$ & Upstream & 0 & 5.5 & 20.5 & 3.0 & 400 & 1.5 & 23.0 & 240 \\
\hline $7 / 8 / 2019$ & Downstream & 0 & 317 & 233 & 34 & 670 & 8 & 248 & 420 \\
\hline $1 / 8 / 2019$ & Upstream & 0 & 31.1 & 23.3 & 3.4 & $6 / 0$ & 8 & 24.8 & 460 \\
\hline 1010/10/7 & Downstream & 0 & 328 & 217 & 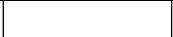 & 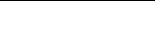 & 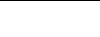 & 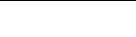 & 160 \\
\hline $1 / 10 / \angle 019$ & Upstream & 0 & 32.0 & 21.1 & - & - & - & - & 80 \\
\hline & Downstream & & & & & & & & 220 \\
\hline$/ / 12 / 2019$ & Upstream & 0 & 35.6 & 21.1 & 2.4 & $6 / 0$ & 1.5 & 24.8 & 120 \\
\hline & Downstream & 0 & & & & & & & 160 \\
\hline $1 / 15 / 2019$ & Upstream & 0 & 32.8 & 23.9 & - & - & - & - & 420 \\
\hline
\end{tabular}

$\mathrm{pH}$ remained within range of standards (6-9) and water temperature did not reach above

$31.7^{\circ} \mathrm{C}$ when monitored. Conductivity was higher than preferred for fish habitats (500 $\mu \mathrm{S} / \mathrm{cm}$ ), but does not fall in the range of being a water quality problem by the KAR standards. There are violations of the 401 KAR 10:031 for surface water standards in DO and e. coli concentrations. The DO was below standard (4.0 ppm instantaneous) when 
there was no precipitation in the region. Precipitation is necessary for high quality water because without it there was no mixing of the water and the water depth began to become lower leading to pooling water from low flow. From July $3^{\text {rd }}$ to July $16^{\text {th }}$ of 2019 there was zero precipitation recorded in this region. The high temperatures peaked on July $12^{\text {th }}$, 2019 at $35.6{ }^{\circ} \mathrm{C}$ causing the DO to reach its lowest value in the testing period at $2.4 \mathrm{ppm}$. The atmospheric temperatures were higher than average in Louisville, with June of 2019 being about $0.33^{\circ} \mathrm{C}$ higher than average and July of 2019 was about $1.5^{\circ} \mathrm{C}$ higher than average from 1948-2000 (NOAA, 2020).

The e. coli concentrations found were high for both the monthly average and most individual samples with 5 of the 22 samples in total being over 240 e. coli colonies per $100 \mathrm{~mL}$. Table 5.2 shows the five day averages during the two 30-day periods.

Table 5.2 Beargrass Creek Average E. Coli Concentrations per $100 \mathrm{~mL}$ of sample

\begin{tabular}{|l|r|}
\hline \multicolumn{2}{|c|}{$\begin{array}{c}\text { E. Coli Concentration per } 100 \mathrm{~mL} \text { of } \\
\text { sample: 30-day Average }\end{array}$} \\
\hline June- Downstream & 1460 \\
\hline June- Upstream & 1760 \\
\hline July- Downstream & 683.3 \\
\hline July- Upstream & 636.7 \\
\hline
\end{tabular}

These waters have higher average concentrations of e. coli than is permitted in 30-days. June results yields higher e. coli concentrations than July results because of the amount of precipitation and the presence of combined sewer overflows (CSOs) on this creek. In 2019, MSD reported 2 overflow events during the testing period on Beargrass Creek at CSOs located upstream of the sampling location (Louisville, 2019). The overflows occurred on June $23^{\text {rd }}$ and June $24^{\text {th }}$ with zero events in the July testing period (Louisville, 2019). In the June testing period, Louisville, KY experienced 6 days of 
precipitation (4.44 inches of rainfall), where in the July testing period there was only 2 days with precipitation (0.45 inches of rainfall) (NOAA, 2020).

\section{Control- Wilson Creek}

This natural stream in Bernheim Forest (on the border of Nelson County, KY) was used for the control creek. Wilson Creek testing period is the same time period as Beargrass Creek. All tests were completed at dawn and proper cold storage was used for transporting samples. The waters at this location had low turbidity and consistent flow reported on every sampling trip. There were also populations of fish observed during every visit. The results of this stream was hypothesized to indicate pristine quality water, but this was proven incorrect due to high concentrations of e. coli. Table 5.3 below is a table of the results of the June through July tests of Wilson Creek. The dates in the table in blue indicate days with precipitation.

Table 5.3 Wilson Creek Results from Water Quality tests and Climate data

\begin{tabular}{|c|c|c|c|c|c|c|c|c|c|}
\hline \multirow{2}{*}{ Date } & \multirow{2}{*}{ Site } & \multirow{2}{*}{$\begin{array}{l}\text { Precipitation } \\
\text { (In.) }\end{array}$} & \multicolumn{2}{|c|}{ Atm. Temp. $\left({ }^{\circ} \mathrm{C}\right)$} & \multirow{2}{*}{$\begin{array}{c}\text { Dissolved } \\
\text { Oxygen (ppm) }\end{array}$} & \multirow{2}{*}{$\begin{array}{c}\text { Conductivity } \\
(\mu \mathrm{S} / \mathrm{cm})\end{array}$} & \multirow{2}{*}{$\mathrm{pH}(\mathrm{SU})$} & \multirow{2}{*}{\begin{tabular}{|c|} 
Water \\
Temp $\left({ }^{\circ} \mathrm{C}\right)$
\end{tabular}} & \multirow{2}{*}{$\begin{array}{l}\text { E.coli concentration } \\
\text { per } 100 \mathrm{~mL} \text { of sample }\end{array}$} \\
\hline & & & High & Low & & & & & \\
\hline \multirow{2}{*}{$6 / 19 / 2019$} & Upstream & \multirow{2}{*}{0} & \multirow{2}{*}{27.2} & \multirow{2}{*}{21.1} & \multirow{2}{*}{7.6} & \multirow{2}{*}{410} & \multirow{2}{*}{7.5} & \multirow{2}{*}{18.9} & 550 \\
\hline & Downstream & & & & & & & & 630 \\
\hline \multirow{2}{*}{$6 / 22 / 2019$} & Upstream & \multirow{2}{*}{2.25} & \multirow{2}{*}{27.8} & \multirow{2}{*}{19.4} & \multirow{2}{*}{ - } & \multirow{2}{*}{ - } & \multirow{2}{*}{-} & \multirow{2}{*}{ - } & 690 \\
\hline & Downstream & & & & & & & & 680 \\
\hline \multirow{2}{*}{$6 / 24 / 2019$} & Upstream & \multirow{2}{*}{0.08} & \multirow{2}{*}{26.7} & \multirow{2}{*}{21.7} & \multirow{2}{*}{6.8} & \multirow{2}{*}{460} & \multirow{2}{*}{8} & 188 & 420 \\
\hline & Downstream & & & & & & & 10.0 & 480 \\
\hline $6 / 26 / 2019$ & Upstream & 0 & 30 & 194 & - & - & - & - & 180 \\
\hline $0 / \angle 0 / \angle 019$ & Downstream & 0 & 30 & 19.4 & - & - & - & - & 250 \\
\hline $6 / 28 / 2019$ & Upstream & 0 & 328 & 211 & 7 & 460 & 8 & 205 & 280 \\
\hline $0 / \angle 8 / \angle 019$ & Downstream & 0 & 32.8 & 21.1 & 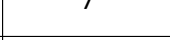 & 400 & 8 & 20.3 & 340 \\
\hline $7 / 1 / 2019$ & Upstream & 15 & 339 & 233 & - & - & - & - & 810 \\
\hline$/ / 1 / 2019$ & Downstream & 1.5 & 33.9 & 23.3 & - & - & - & - & 420 \\
\hline $7 / 3 / 2019$ & Upstream & 0.44 & 33.9 & 23.9 & 6.2 & 410 & 8 & 205 & 1580 \\
\hline$/ / 3 / \angle 019$ & Downstream & 0.44 & 33.9 & 23.9 & 0.2 & 410 & 8 & 20.5 & 1900 \\
\hline $7 / 8 / 2019$ & Upstream & 0 & 31.7 & 23.3 & 6 & 500 & 8.5 & 22.5 & 650 \\
\hline //8/2019 & Downstream & 0 & 31.7 & 23.3 & 0 & 500 & 8.5 & $2 \angle .3$ & 530 \\
\hline $7 / 10 / 2019$ & Upstream & 0 & & 21.7 & - & - & & & 140 \\
\hline$/ / 10 / 2019$ & Downstream & 0 & 32.8 & 21.1 & - & - & - & - & 630 \\
\hline $7 / 12 / 2019$ & Upstream & 0 & 356 & 217 & 76 & 500 & 8 & 23 & 160 \\
\hline$/ / 12 /<019$ & Downstream & 0 & 30.0 & 21.7 & 1.0 & 300 & 0 & 20 & 120 \\
\hline $7 / 15 / 2019$ & Upstream & 0 & 328 & 230 & - & - & - & - & 40 \\
\hline //15/2019 & Downstream & 0 & 32.8 & 23.9 & - & - & - & - & 100 \\
\hline
\end{tabular}


The DO, conductivity, $\mathrm{pH}$, and water temperature of this stream were all within standards for the state. These four field tests for water quality were consistently within standard throughout the testing period. The DO was above standards for Kentucky because of the high levels of vegetative coverage (shade) from the wooded surroundings and the riffle that would mix the waters. The concentrations of e. coli were a problem at this location. The lab tests yielded high concentrations of e. coli per $100 \mathrm{~mL}$ of sample on average in June and July. Table 5.4 outlines these results below.

Table 5.4 Wilson Creek Average E. Coli Concentrations per $100 \mathrm{~mL}$ of sample

\begin{tabular}{|l|r|}
\hline \multicolumn{2}{|c|}{$\begin{array}{c}\text { E. Coli Concentration per } 100 \mathrm{~mL} \text { of } \\
\text { sample: } 30 \text {-day Average }\end{array}$} \\
\hline June- Upstream & 424 \\
\hline June- Downstream & 476 \\
\hline July- Upstream & 563.3 \\
\hline July- Downstream & 616.7 \\
\hline
\end{tabular}

The days with zero precipitation resulted in lower levels of e. coli than days with precipitation. The number of days with a precipitation event recorded in the June testing period were three resulting in 2.58 inches of rainfall (NOAA, 2020). In the July testing period, there were five days of rainfall resulting in a total of 2.07 inches (NOAA, 2020). The largest concentrations of e. coli per $100 \mathrm{~mL}$ sample were the result of the longest stretch of continuous daily precipitation (July $1^{\text {st }}, 2019-$ July $\left.5^{\text {th }}, 2019\right)$. The average temperature for June in the county was about $0.61^{\circ} \mathrm{C}$ lower than the average from 1901 to 2000 (NOAA, 2020). The average temperature in July was about $1.1{ }^{\circ} \mathrm{C}$ higher than the average from 1901-2000 (NOAA, 2020). 


\section{$\underline{\text { Mill Creek }}$}

The following results are for field and lab water quality tests conducted on samples from Mill Creek. The results are split into a July, 2019 testing period and an August, 2019 testing period. On a given date, six sites on Mill Creek were tested in a random order. For each site, the equipment used was washed with distilled water or sterilized in the lab before testing the next location. Tables 5.5 (a) and (b) display the results of the Mill Creek tests in July and in August. The dates in the table in blue indicate days with precipitation. 
Table 5.5 (a) Mill Creek Results from Water Quality Tests and Climate data (July, 2019 Testing Period)

\begin{tabular}{|c|c|c|c|c|c|c|c|c|c|}
\hline \multirow{2}{*}{ Date } & \multirow{2}{*}{ Site } & \multirow{2}{*}{$\begin{array}{c}\text { Precipitation } \\
\text { (in.) }\end{array}$} & \multicolumn{2}{|c|}{ Atmospheric Temperature $\left({ }^{\circ} \mathrm{C}\right)$} & \multirow{2}{*}{$\begin{array}{c}\text { Dissolved } \\
\text { Oxygen (ppm) }\end{array}$} & \multirow{2}{*}{\begin{tabular}{|c|}
$\begin{array}{c}\text { Conductivity } \\
(\mu \mathrm{S} / \mathrm{cm})\end{array}$ \\
\end{tabular}} & \multirow{2}{*}{$\mathrm{pH}(\mathrm{SU})$} & \multirow{2}{*}{$\begin{array}{c}\text { Water } \\
\text { Temp }\left({ }^{\circ} \mathrm{C}\right)\end{array}$} & \multirow{2}{*}{$\begin{array}{l}\text { E. Coli Concentration } \\
\text { per } 100 \mathrm{~mL} \text { of sample }\end{array}$} \\
\hline & & & High & Low & & & & & \\
\hline \multirow{6}{*}{$7 / 17 / 2019$} & 1 & \multirow{6}{*}{0.11} & \multirow{6}{*}{31.7} & \multirow{6}{*}{23.3} & - & - & - & - & 470 \\
\hline & 2 & & & & - & - & - & - & 100 \\
\hline & 3 & & & & - & - & - & - & 1050 \\
\hline & 4 & & & & - & - & - & - & 170 \\
\hline & 5 & & & & - & - & - & - & 90 \\
\hline & 6 & & & & - & - & - & - & 950 \\
\hline \multirow{6}{*}{$7 / 20 / 2019$} & 1 & \multirow{6}{*}{-} & \multirow{6}{*}{35} & \multirow{6}{*}{25.6} & 1 & 150 & 6.75 & 30.5 & 780 \\
\hline & 2 & & & & 3.2 & 200 & 7.5 & 29 & 100 \\
\hline & 3 & & & & 2 & 230 & 7.25 & 26.4 & 120 \\
\hline & 4 & & & & 2 & 180 & 7.5 & 28 & 70 \\
\hline & 5 & & & & 1.8 & 170 & 7.25 & 28 & 70 \\
\hline & 6 & & & & 3.4 & 150 & 7.5 & 25.8 & 450 \\
\hline \multirow{6}{*}{$7 / 22 / 2019$} & 1 & \multirow{6}{*}{0.45} & \multirow{6}{*}{33.3} & \multirow{6}{*}{22.2} & - & - & - & - & 2100 \\
\hline & 2 & & & & - & - & - & - & 60 \\
\hline & 3 & & & & - & - & - & - & 70 \\
\hline & 4 & & & & - & - & - & - & 90 \\
\hline & 5 & & & & - & - & - & - & 160 \\
\hline & 6 & & & & - & - & - & - & 0 \\
\hline \multirow{6}{*}{$7 / 24 / 2019$} & 1 & & & & 1 & 170 & 7 & 21 & 470 \\
\hline & 2 & & & & 0.7 & 210 & 7 & 25 & 60 \\
\hline & 3 & - & 289 & 167 & 3.2 & 170 & 7.5 & 24 & 40 \\
\hline & 4 & - & 28.9 & 16.1 & 3.2 & 230 & 7.5 & 22 & 90 \\
\hline & 5 & & & & 3.3 & 170 & 7.5 & 22 & 110 \\
\hline & 6 & & & & 4.6 & 160 & 7.5 & 20 & 100 \\
\hline & 1 & & & & - & - & - & - & 330 \\
\hline & 2 & & & & - & - & - & - & 20 \\
\hline 7/27/2019 & 3 & 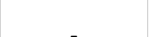 & 311 & 183 & - & - & - & - & 110 \\
\hline $1 / 21 / 2019$ & 4 & - & 31.1 & 10.3 & - & - & - & - & 50 \\
\hline & 5 & & & & - & - & - & - & 40 \\
\hline & 6 & & & & - & - & - & - & 390 \\
\hline & 1 & & & & 1.4 & 170 & 6.75 & 24 & 1300 \\
\hline & 2 & & & & 1.9 & 220 & 7 & 26 & 20 \\
\hline $7 / 30 / 2019$ & 3 & 037 & 333 & 227 & 3.4 & 320 & 7.5 & 24 & 80 \\
\hline $1 / 30 /<019$ & 4 & 0.32 & 33.3 & $2 \angle .2$ & 3.4 & 180 & 7.5 & 26 & 20 \\
\hline & 5 & & & & 2.8 & 160 & 7 & 24.4 & 470 \\
\hline & 6 & & & & 5.1 & 200 & 7.5 & 23.8 & 30 \\
\hline & 1 & & & & 1.1 & 170 & 7 & 24 & 480 \\
\hline & 2 & & & & 0.7 & 230 & 7.25 & 26 & 40 \\
\hline $7 / 31 / 2019$ & 3 & - & 30.6 & 211 & 2.3 & 330 & 7.5 & 22 & 30 \\
\hline$/ / 31 / 2019$ & 4 & - & 30.6 & 21.1 & 2.3 & 190 & 8 & 25 & 10 \\
\hline & 5 & & & & 3.2 & 170 & 7.25 & 23.2 & 20 \\
\hline & 6 & & & & 4.1 & 220 & 7.5 & 21.6 & 150 \\
\hline
\end{tabular}


Table 5.5 (b) Mill Creek Results from Water Quality Tests and Climate data (August, 2019 Testing period)

\begin{tabular}{|c|c|c|c|c|c|c|c|c|c|}
\hline \multirow{2}{*}{ Date } & \multirow{2}{*}{ Site } & \multirow{2}{*}{$\begin{array}{c}\text { Precipitation } \\
\text { (in.) }\end{array}$} & \multicolumn{2}{|c|}{ Atmospheric Temperature $\left({ }^{\circ} \mathrm{C}\right)$} & \multirow{2}{*}{$\begin{array}{c}\text { Dissolved } \\
\text { Oxygen (ppm) }\end{array}$} & \multirow{2}{*}{\begin{tabular}{|c|} 
Conductivity \\
$(\mu \mathrm{S} / \mathrm{cm})$
\end{tabular}} & \multirow{2}{*}{$\mathrm{pH}(\mathrm{SU})$} & \multirow{2}{*}{$\begin{array}{c}\text { Water } \\
\text { Temp }\left({ }^{\circ} \mathrm{C}\right)\end{array}$} & \multirow{2}{*}{$\begin{array}{l}\text { E. Coli Concentration } \\
\text { per } 100 \mathrm{~mL} \text { of sample }\end{array}$} \\
\hline & & & High & Low & & & & & \\
\hline \multirow{6}{*}{$8 / 2 / 2019$} & 1 & \multirow{6}{*}{-} & \multirow{6}{*}{31.1} & \multirow{6}{*}{20} & 1 & 170 & 7 & 24 & 500 \\
\hline & 2 & & & & 0.8 & 220 & 7 & 24.2 & 170 \\
\hline & 3 & & & & 2.3 & 370 & 7.5 & 23 & 140 \\
\hline & 4 & & & & 2.4 & 170 & 8.5 & 26 & 20 \\
\hline & 5 & & & & 3 & 180 & 7.5 & 22 & 80 \\
\hline & 6 & & & & 2.8 & 270 & 7.5 & 21 & 10 \\
\hline \multirow{6}{*}{$8 / 5 / 2019$} & 1 & \multirow{6}{*}{-} & \multirow{6}{*}{31.1} & \multirow{6}{*}{22.2} & - & - & - & - & 340 \\
\hline & 2 & & & & - & - & - & - & 840 \\
\hline & 3 & & & & - & - & - & - & 100 \\
\hline & 4 & & & & - & - & - & - & 10 \\
\hline & 5 & & & & - & - & - & - & 60 \\
\hline & 6 & & & & - & - & - & - & 20 \\
\hline \multirow{6}{*}{$8 / 7 / 2019$} & 1 & \multirow{6}{*}{-} & \multirow{6}{*}{32.8} & \multirow{6}{*}{21.7} & 0.6 & 200 & 7 & 23.5 & 330 \\
\hline & 2 & & & & 2 & 210 & 7 & 25 & 1660 \\
\hline & 3 & & & & 1.95 & 420 & 7.5 & 23 & 100 \\
\hline & 4 & & & & 3.6 & 190 & 7.5 & 24.5 & 10 \\
\hline & 5 & & & & 3 & 190 & 7.25 & 23 & 410 \\
\hline & 6 & & & & 2.4 & 310 & 7.5 & 21 & 40 \\
\hline \multirow{6}{*}{$8 / 10 / 2019$} & 1 & \multirow{6}{*}{-} & \multirow{6}{*}{35.6} & \multirow{6}{*}{18.9} & - & - & - & - & 260 \\
\hline & 2 & & & & - & - & - & - & 1890 \\
\hline & 3 & & & & - & - & - & - & 10 \\
\hline & 4 & & & & - & - & - & - & 50 \\
\hline & 5 & & & & - & - & - & - & 270 \\
\hline & 6 & & & & - & - & - & - & 110 \\
\hline & 1 & & & & 1.1 & 190 & 7 & 23 & 590 \\
\hline & 2 & & & & 1 & 150 & 6.75 & 25 & 680 \\
\hline $8 / 14 / 2019$ & 3 & 074 & 30.6 & 211 & 1.2 & 250 & 7 & 24 & 140 \\
\hline $8 / 14 / \angle 019$ & 4 & 0.14 & 30.6 & 21.1 & 2.4 & 200 & 7.5 & 24.9 & 150 \\
\hline & 5 & & & & 3.2 & 160 & 7 & 24.4 & 2050 \\
\hline & 6 & & & & 4.6 & 200 & 7 & 24.3 & 1360 \\
\hline & 1 & & & & 1.2 & 200 & 6.5 & 25 & 340 \\
\hline & 2 & & & & 1.1 & 170 & 7 & 28 & 420 \\
\hline $8 / 17 / 2019$ & 3 & - & & & 1.6 & 250 & 7 & 22.5 & 160 \\
\hline $8 / 1 / / 2019$ & 4 & - & 32.8 & 21.1 & 4.6 & 170 & 8 & 26.2 & 10 \\
\hline & 5 & & & & 2 & 180 & 7 & 26 & 120 \\
\hline & 6 & & & & 2.1 & 210 & 7 & 21 & 230 \\
\hline
\end{tabular}

The climate information of the area depicts high temperatures and precipitation events in 2019 for this region. The average atmospheric temperature for July of 2019 was $1.5^{\circ} \mathrm{C}$ higher than the average from 1948-2000 (NOAA, 2020). In August, the average atmospheric temperature was $1.39{ }^{\circ} \mathrm{C}$ higher than average (NOAA, 2020). During the July testing period, precipitation occurred four times producing a total of 0.92 inches of rainfall. In August only two precipitation events take place resulting in 0.83 inches of rainfall with August 14th producing 0.74 inches of this rainfall (NOAA, 2020). 
For both July and August there were zero days with violations to the KAR standards of surface water quality in the categories of $\mathrm{pH}$ and water temperature. The conductivity levels were also in the recommended zone to sustain fish populations. These three parameters are graphed as the average of the six sites below in figure 5.1 for $\mathrm{pH}$, figure 5.2 for water temperature, and figure 5.3 for conductivity.

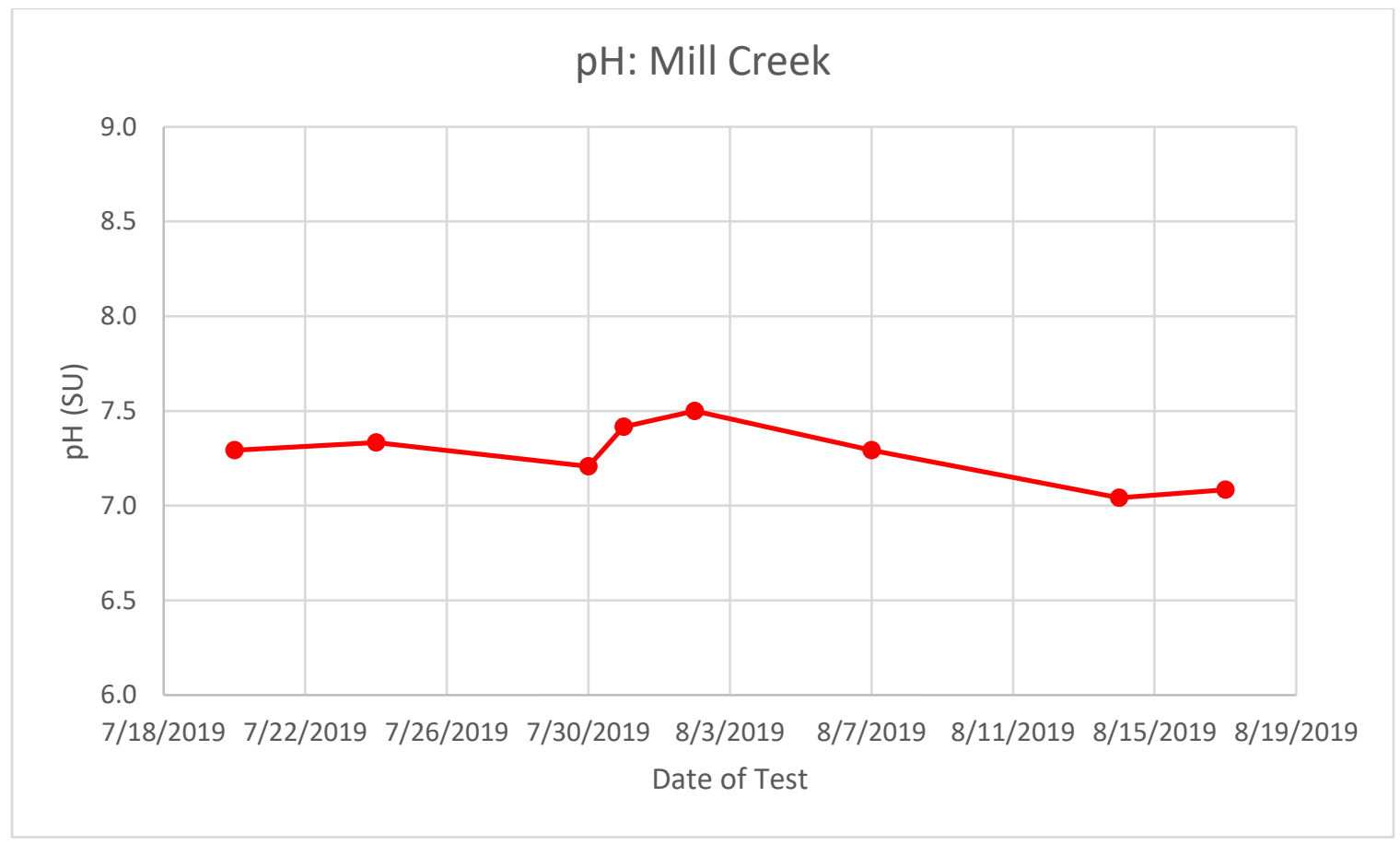

Figure 5.1 pH Average for the 6 gaging sites for Mill Creek 


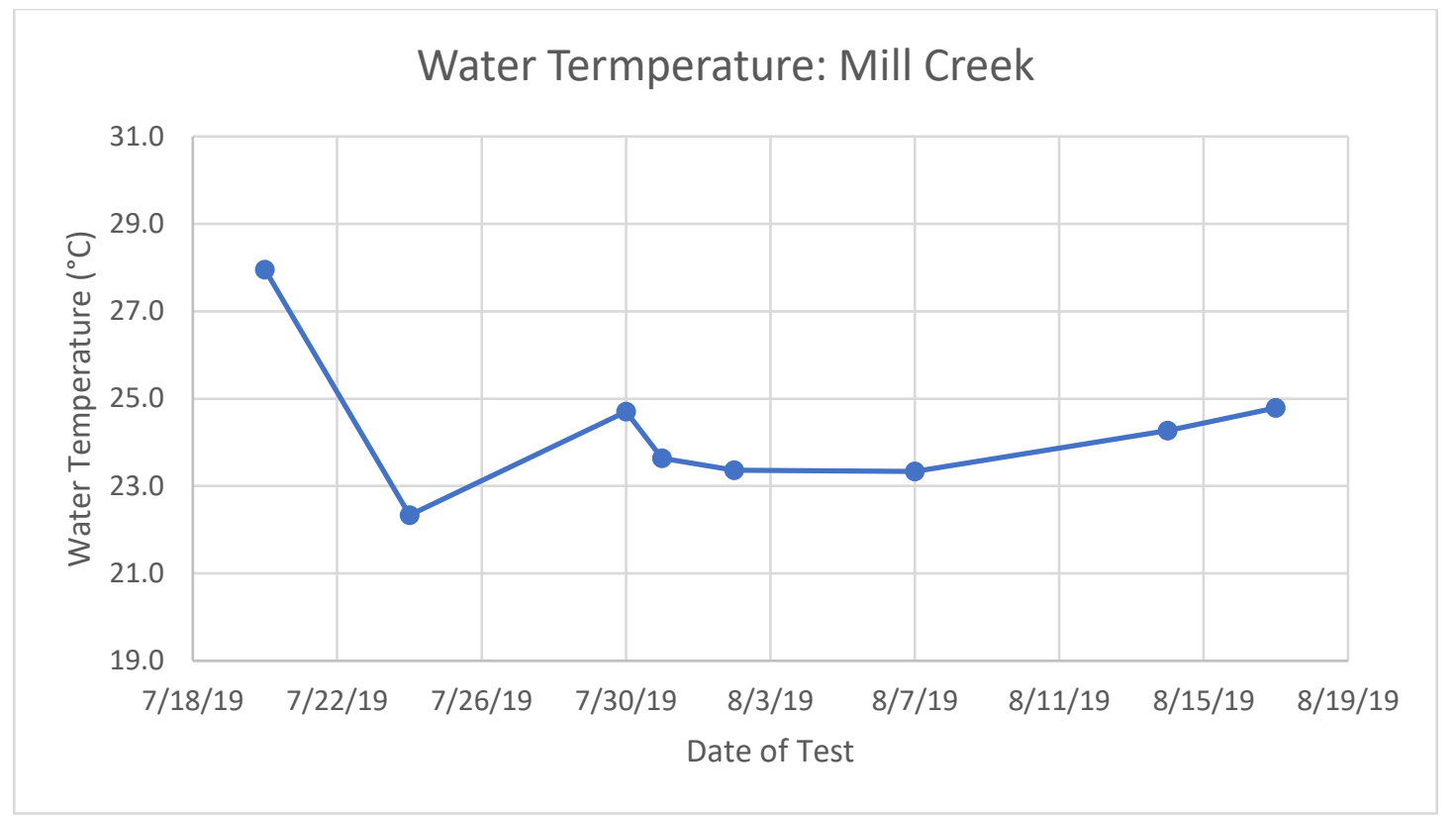

Figure 5.2 Water Temperature Average for the 6 gaging sites for Mill Creek

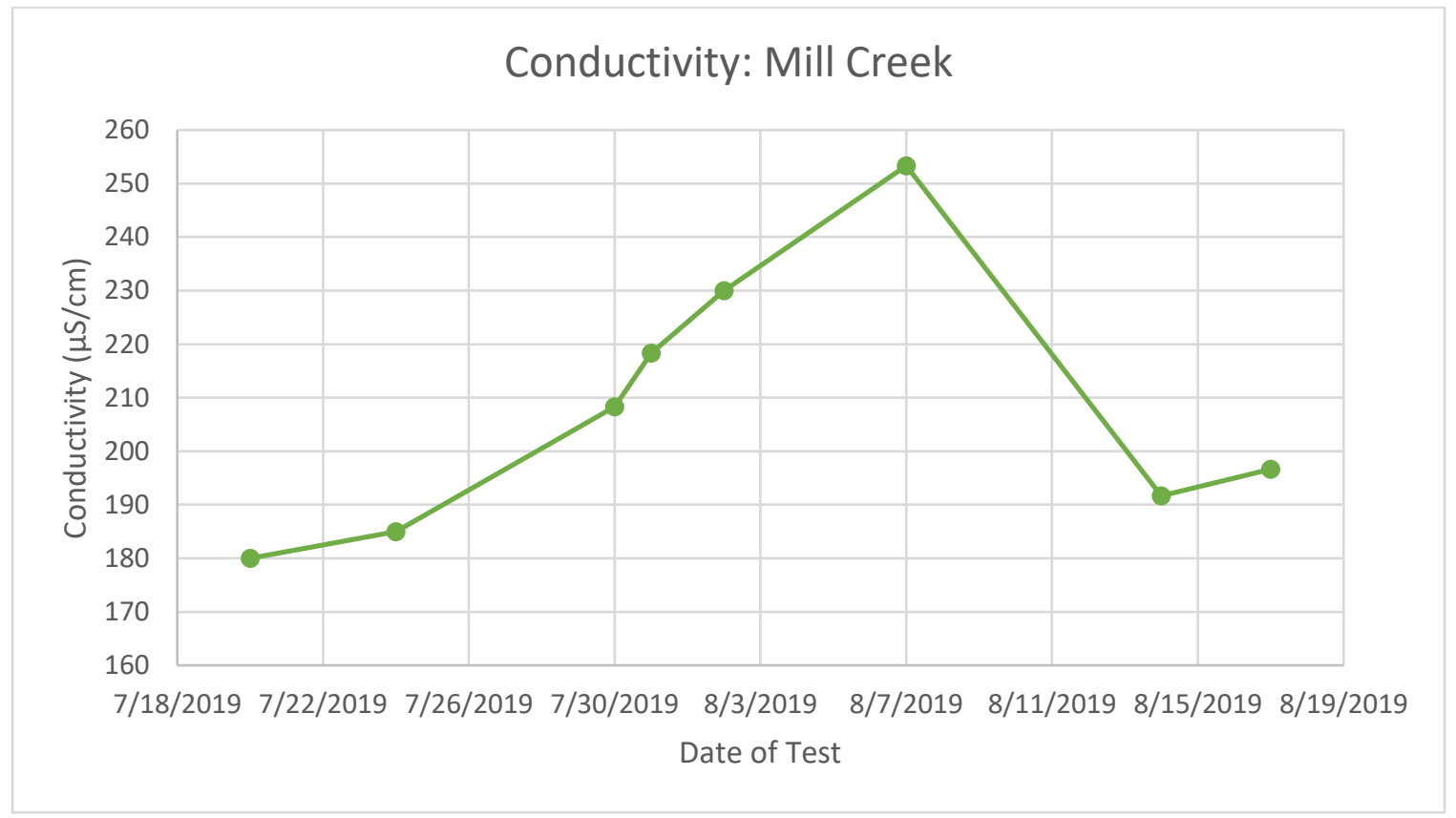

Figure 5.3 Conductivity Average for the 6 gaging sites for Mill Creek

The violations in the water quality standards pertained to the concentrations in DO and e. coli. The before and after of the BACI method pertain to Mill Creek with the before data 
utilized from the 2016 synthesis report by MSD of streams in Jefferson County. In 2016, MSD reported that their sole monitoring location on Mill Creek found the dissolved oxygen levels were fair and rising (Parrott, 2016). In July and August of 2019, sites 1, 2, $3, \& 5$ were below 4.0 ppm of dissolved oxygen the entire study. Site 4 levels were above $4.0 \mathrm{ppm}$ of dissolved oxygen the last day. Site 6 had levels above $4.0 \mathrm{ppm}$ of dissolved oxygen in $50 \%$ of the field tests. Graphs of DO concentrations for each site are below in figures 5.4 (a-f). Individual graphs for unique data points at each site illustrate increases or decreases of DO concentration based on climatic and environmental factors of the region.

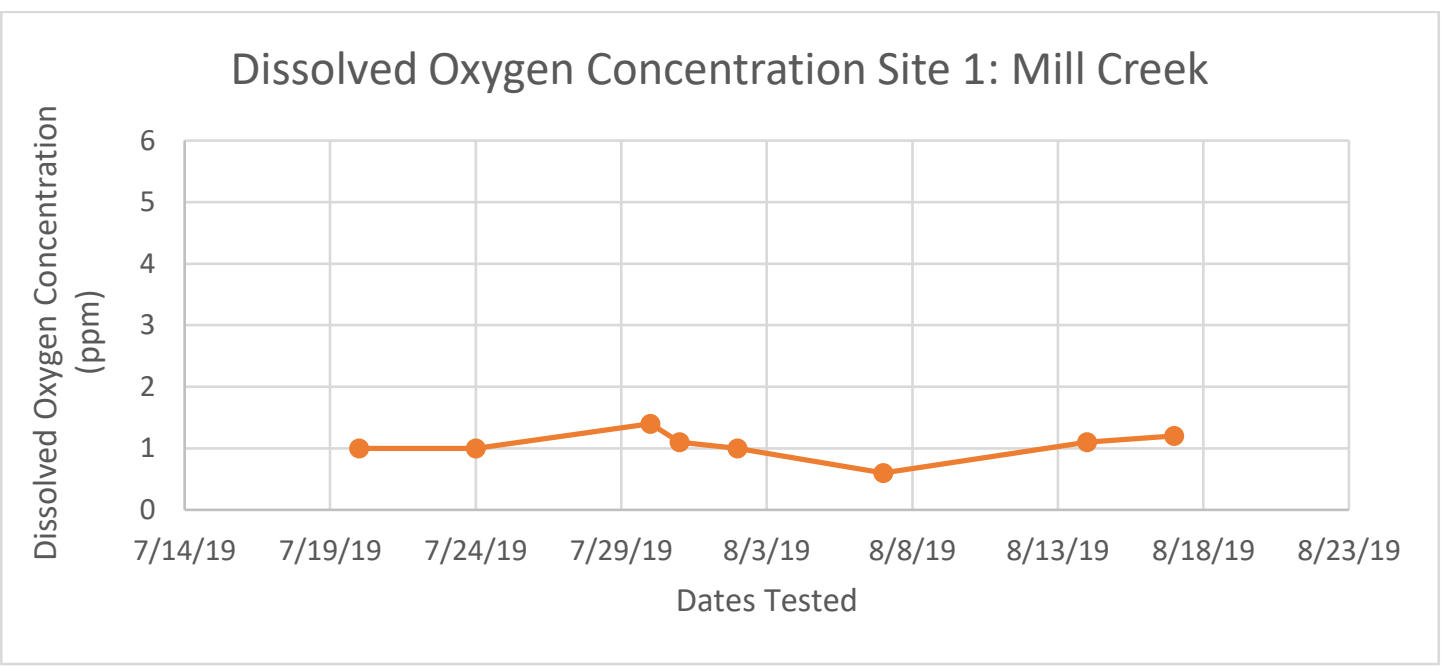

Figure 5.4 (a) Mill Creek Dissolved Oxygen (DO) Concentrations for site 1 

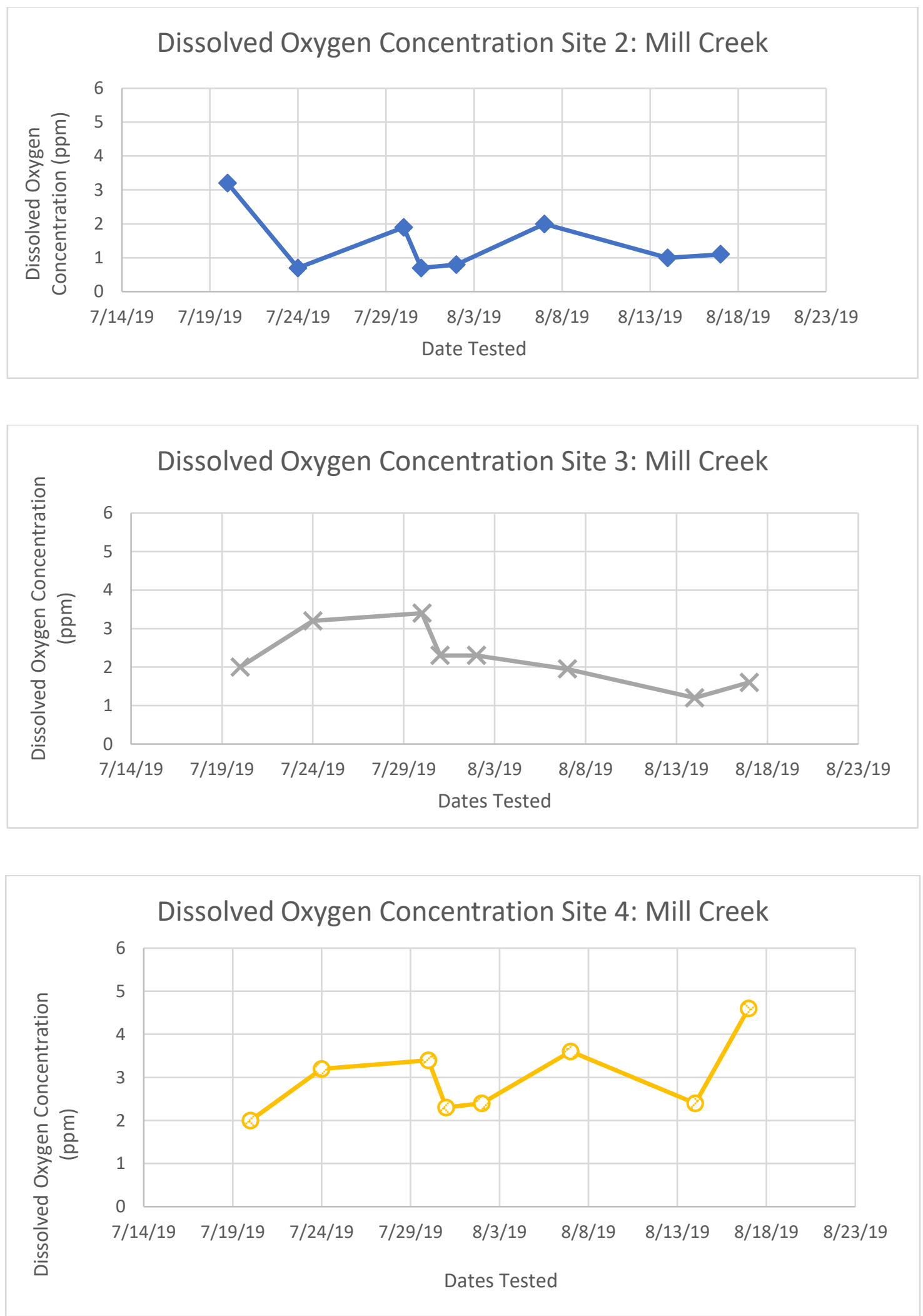

Figure 5.4 (b-d) Mill Creek Dissolved Oxygen (DO) Concentrations for sites 2-4 

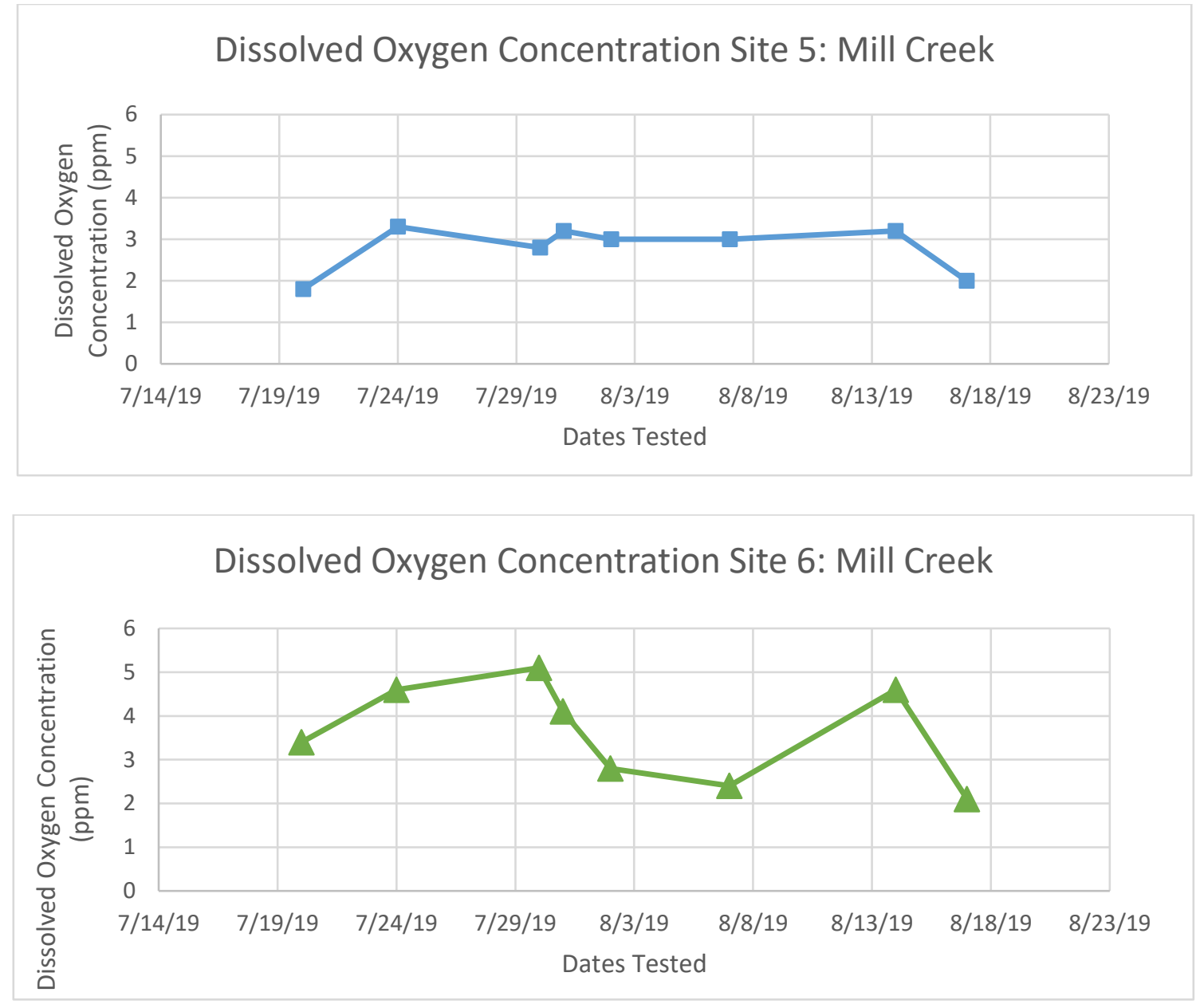

Figure 5.4 (e-f) Mill Creek Dissolved Oxygen (DO) Concentrations for sites 5-6

The dissolved oxygen has been found to be lower in warmer waters due to the faster motion of the water molecules (Allan, 2007). The decrease from a DO concentration rating of fair to poor (from the 2016 report to these 2019 results) is a result of the regions high temperatures without precipitation as seen with the NOAA data. Rainfall in the summer increases the average dissolved oxygen concentration in water body by mixing and cooling the water (Allan, 2007). In this study, the average DO for each site on days without rain was less than the DO on the days with rain. From July $3^{\text {rd }}$ to July $16^{\text {th }}$ and from July $31^{\text {st }}$ to August $12^{\text {th }}$ of 2019 there were zero days with precipitation, but temperatures reached highs up to $35^{\circ} \mathrm{C}$. In this time, the water only 
reached above Kentucky standards for DO the first day of the period without rainfall at one site. During the period of time without precipitation in the Mill Creek study, 5 of the 6 sites decreased in DO concentration over time while temperatures rose from $30.6{ }^{\circ} \mathrm{C}$ to a high of $35.6^{\circ} \mathrm{C}$ on the August $10^{\text {th }}$. Temperatures dropped on August $13^{\text {th }}$ and precipitation was recorded for two days straight after. After this rainless period, during the rainfall testing day of August $14^{\text {th }}, 2019$, half of the sites increased in DO levels with one location's concentration moving above regulations for Kentucky.

The severity of the deterioration in the water quality of Mill Creek is illustrated when compared to other local streams using the Before-After-Control-Impact (BACI) method. A comparison of DO concentrations for Mill Creek to the control and impacted sites are in the following graph, in figure 5.5. 


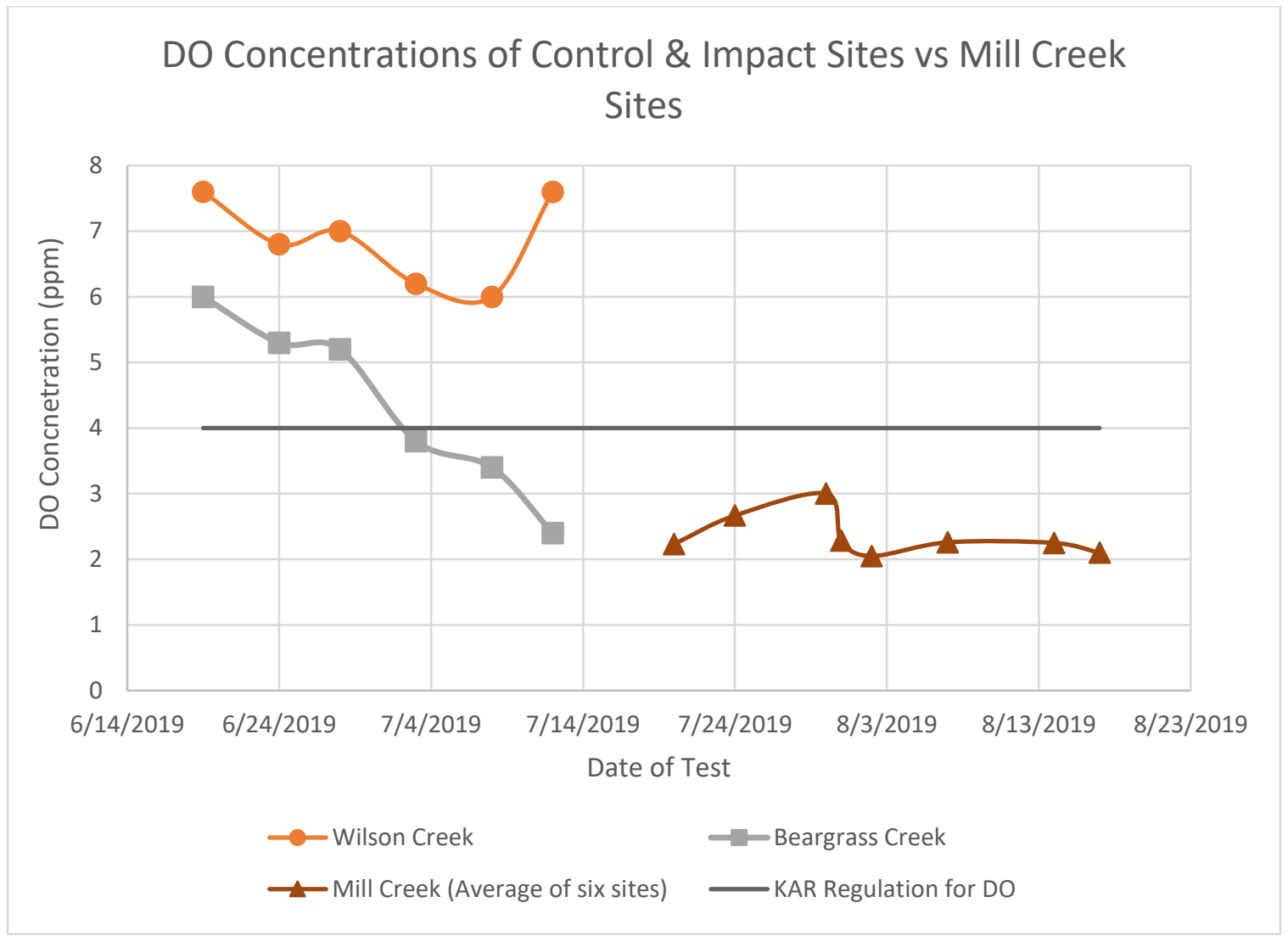

Figure 5.5 DO Concentrations of Control \& Impact sites vs Mill Creek sites

The control creek (C) in BACI was Wilson Creek, which always contained acceptable levels of dissolved oxygen. This is the result of the canopy coverage of vegetation in the wooded area keeping water temperatures down with shading. Shading can keep water temperatures down, reduce greenhouse gases like carbon dioxide that absorb heat, and reduce evaporation allowing higher volume for flow rates in the creek to maintain movement for oxygen to be captured from the atmosphere. This is compared to the urban stream with removed canopy coverage for urban expansion, Mill Creek, where DO concentrations were always below standard. This result indicates that replanting canopy coverage removed during construction of urban and suburban areas could be a solution for urban streams to combat high temperatures. Mill Creek contained foliage on either 
side of the stream, but for large stretches not within the riparian zone directly along the creeks bank. Therefore, the stream was exposed to the solar radiation and carbon dioxide from human activity in the region. The Creek was noticeably pooled in parts during times of low rainfall, leading to less reoxygenation. This is similar to Beargrass Creek, the impacted creek (I). DO was found to be below standard at this location with values closer to Mill Creek than Wilson Creek. Beargrass Creek is an urban stream with similar conditions of less foliage for shading and low water levels. This requires Beargrass Creek and Mill Creek to depend on precipitation for mixing the waters to restore DO levels, but without physical characteristics to maintain restored levels. Therefore, DO will be a problem for the quality of these urban streams during the high temperatures of the summer.

E. coli concentrations of grab samples were tested in the biology lab after proper storage and transportation from the field. Graphs of the concentration for each site are below in figure 5.6 (a-f). These individual graphs for unique data points at each site illustrate increases or decreases of e. coli concentrations. The concentrations for each site then is analyzed with the unique environmental and hydrologic factors of the creek, including the climate of that day. This will allow for trends to be discovered for locations along the stream with more data points. 

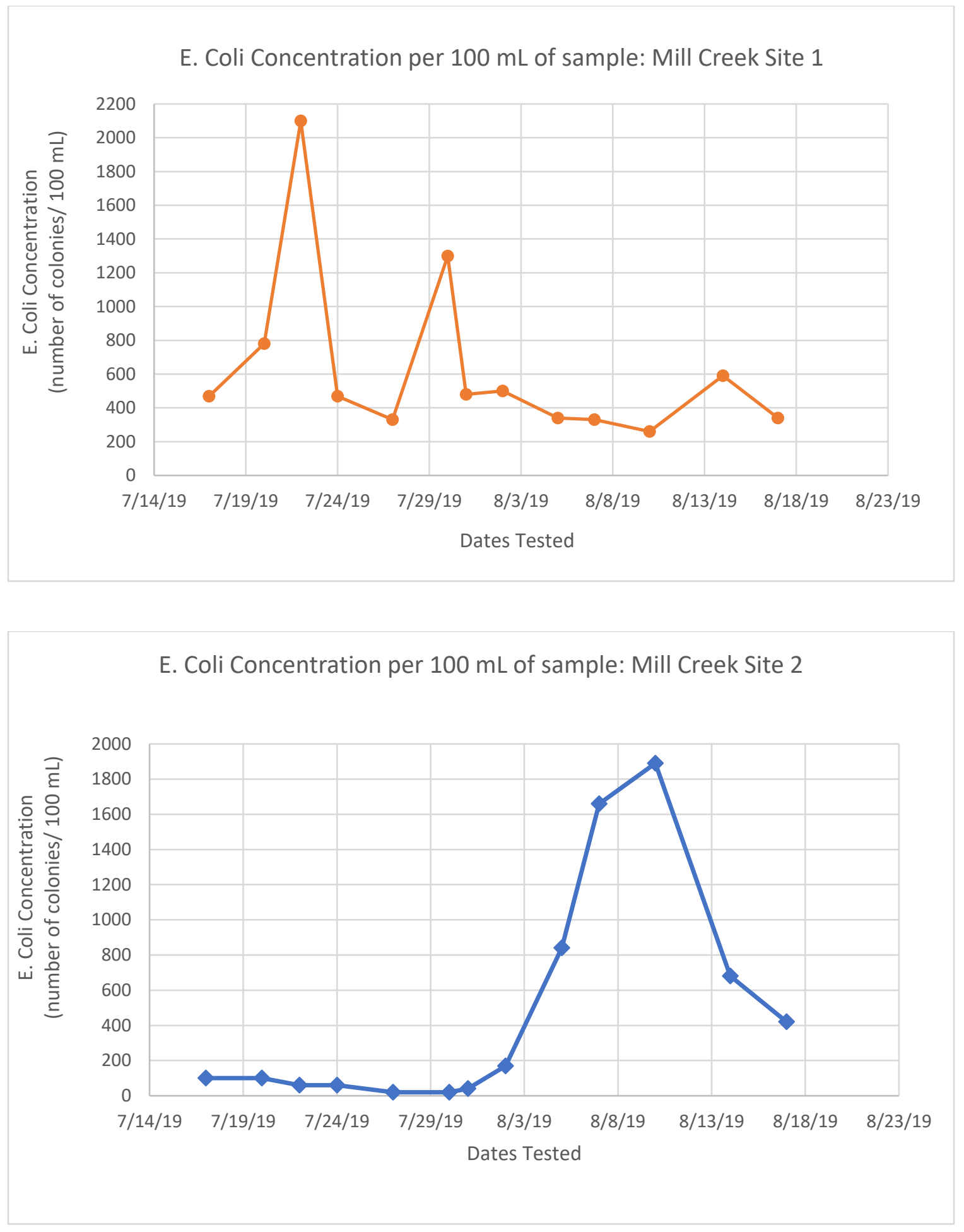

Figure 5.6 (a-b) Mill Creek E. Coli Concentrations for sites 1-2 

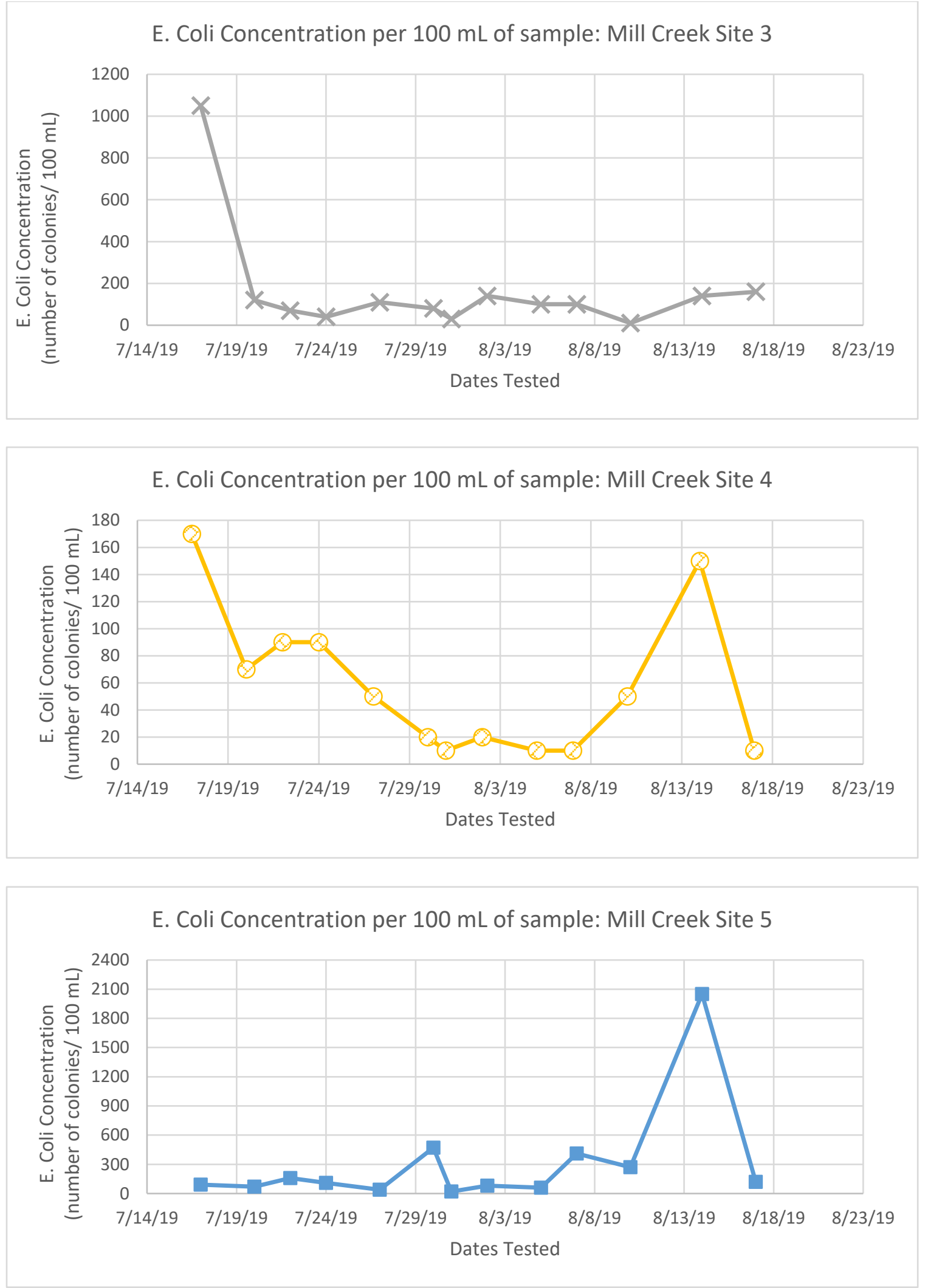

Figure 5.6 (c-e) Mill Creek E. Coli Concentrations for sites 3-5 


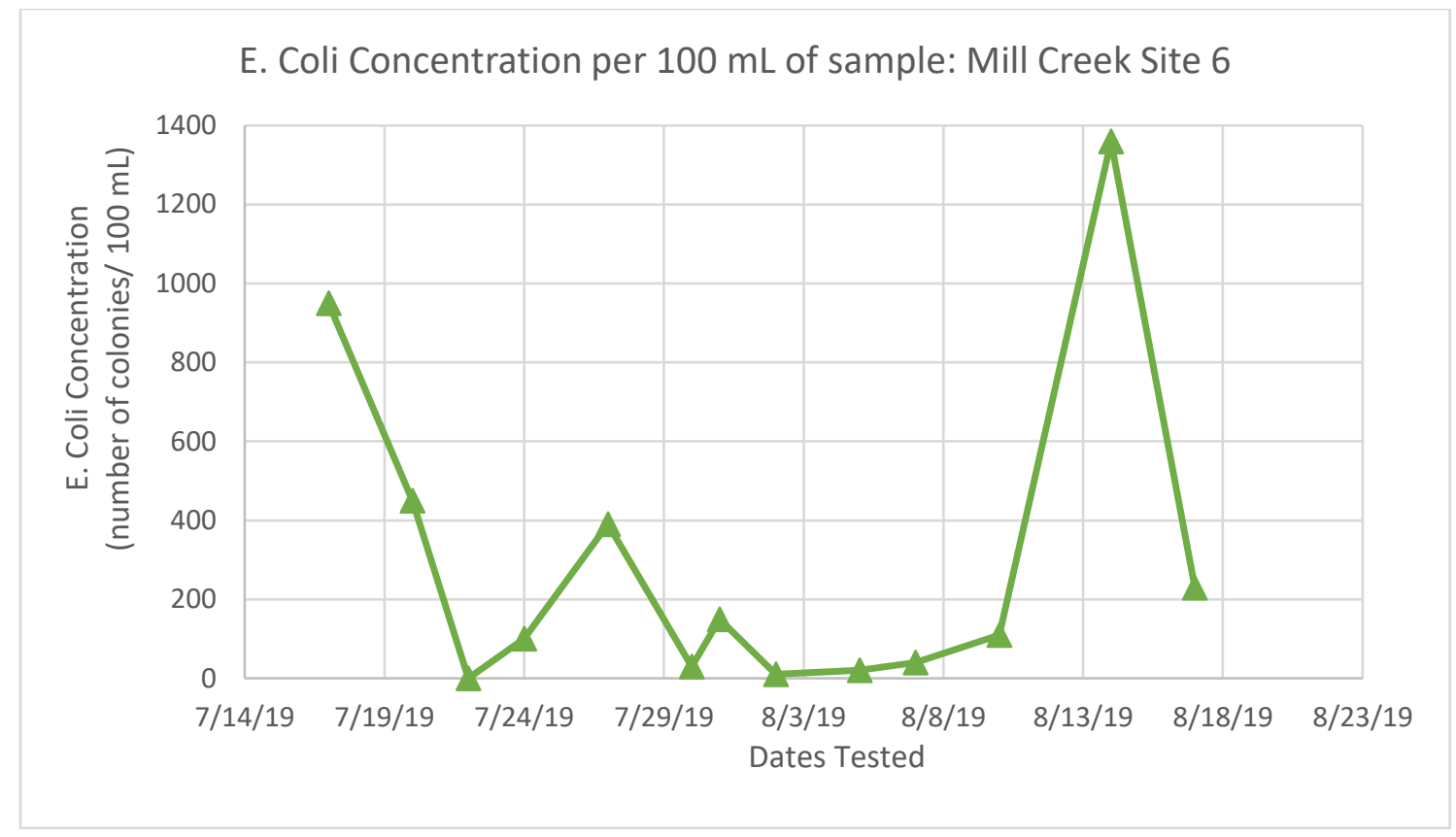

Figure 5.6 (f) Mill Creek E. Coli Concentrations for site 6

One site was up to standard for acceptable e. coli levels in both July and August. This location on Mill Creek was site 4. Site 2 resulted in acceptable e. coli concentrations in July, but not August. Inversely, site 3 contained acceptable e. coli concentrations in August, but not July. The five sample geometric means are how the KAR standards determine the quality of the water instead of an instantaneous single sample result. The geometric means for each site in the July and August testing periods are below in Table 5.6.

Table 5.6 Mill Creek Average E. Coli Concentrations per $100 \mathrm{~mL}$ of sample

\begin{tabular}{|r|r|l|}
\hline \multicolumn{5}{|c|}{ E. Coli concentration per $100 \mathrm{~mL}$ of sample: 30-day Average } \\
\hline Site & July & August \\
\hline 1 & 847 & \\
\hline 2 & 57 & 393 \\
\hline 3 & 214 & 943 \\
\hline 4 & 71 & 108 \\
\hline 5 & 137 & 42 \\
\hline 6 & 296 & 498 \\
\hline & & 295 \\
\hline
\end{tabular}


E. Coli concentration values range, but all six sites exhibited the highest concentration of e. coli on days with precipitation events. Site 1 had the overall highest concentrations of e. coli and the highest single day concentration recorded at 2100 colonies per $100 \mathrm{~mL}$ of sample on July $22^{\text {nd }}, 2019$. Site 2 yielded the month with the highest average in August, after a month in July of having acceptable concentrations.

In 2016, the synthesis report stated that fecal coliform were at good levels within the creek and staying consistent at this level (Parrott, 2016). This project has found high concentrations of the fecal coliform bacteria e. coli were over regulation within the creek at 5 of the 6 locations used to sample from. Based on this it is quite clear that there has been a water quality impact to this urban stream from the environment surrounding this creek that is discharging urban pollutants into the water when rainfall occurs. The e. coli levels of all six sampling locations were highest during events of precipitation. On average, a site had about a $308 \%$ increase in e. coli on a day of precipitation over 0.1 inches than a day with zero precipitation. In both months, the single day highs in concentration for any site for the month came on the days with the highest precipitation total of the testing period. These were 2100 colonies per $100 \mathrm{~mL}$ of sample in July with 0.45 inches of rain and 2050 colonies per $100 \mathrm{~mL}$ of sample in August with 0.74 inches of rain. With urban sprawl continuing to increase the percentage of impervious land use and reduce natural landscapes in the watershed, there will be a continued rise in urban runoff to this stream resulting in higher concentrations of e. coli.

Comparing to the impacted stream (I- South Fork Beargrass Creek), this urban stream had poor water quality containing higher e. coli concentrations on average than the Mill Creek locations. The e. coli concentration at the control stream (C- Wilson 
Creek) were not within Kentucky regulations either and on average worse than most of Mill Creek (5 of 6 sites each month). Figure 5.7 (a) illustrates the geometric mean of e. coli concentrations for each testing period for the control and impacted sites tested.

Figure 5.7 (b) illustrates the geometric mean of e. coli concentration as the average of each site in the July and August testing period. 


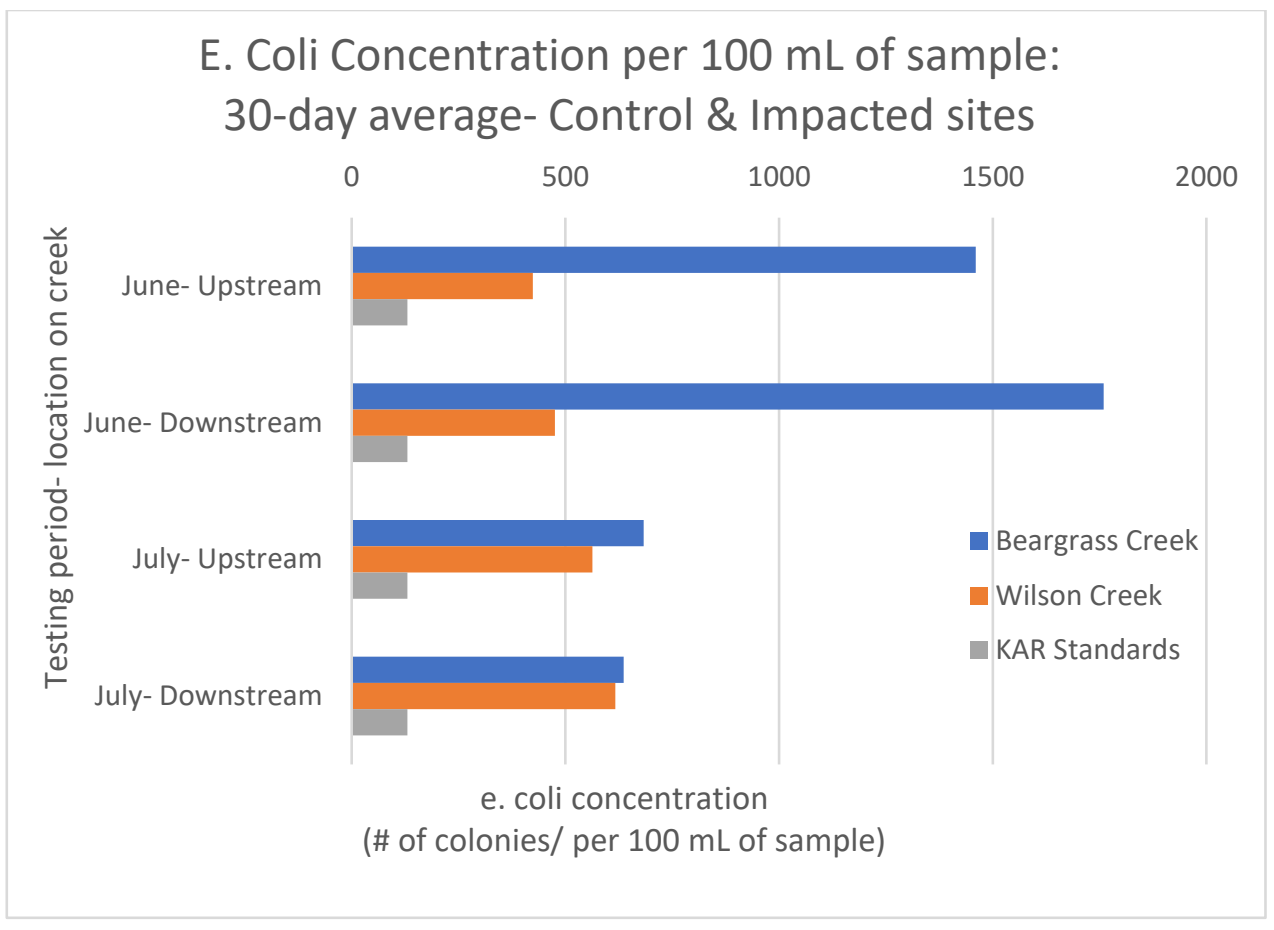

Figure 5.7 (a) E. Coli Concentration per $100 \mathrm{~mL}$ of sample: 30-day average:

Beargrass Creek \& Wilson Creek

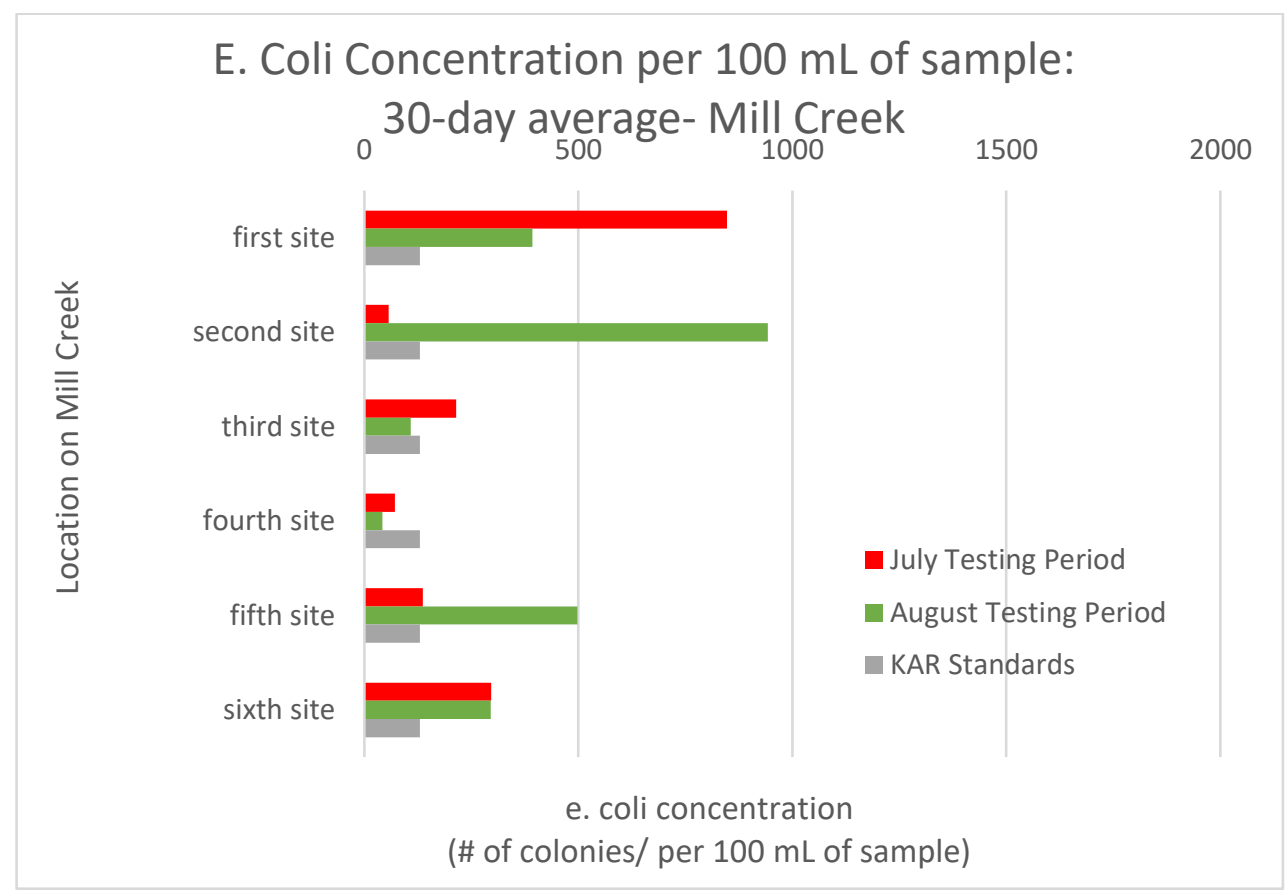

Figure 5.7 (b) E. Coli Concentration per $100 \mathrm{~mL}$ of sample: 30-day average: Mill Creek 
Mill Creek was closer in values for e. coli concentration to Wilson Creek than Beargrass Creek. The reason is that Mill Creek and Wilson Creek do not contain CSOs, but Beargrass Creek does. CSOs by design discharges domestic wastewater with fecal contamination mixing with storm water directly into Beargrass Creek whenever the storm sewers cannot handle the surface runoff. In comparison, other streams receive concentrations of e. coli from surface runoff. Surface runoff is a non-point source pollutant whereas CSOs are point-source pollutants, therefore the e. coli concentrations would be expected to be closer to Wilson Creek than Beargrass Creek (Basic, 2018) (Nonpoint, 2017). The values seen on Wilson Creek for e. coli could be the result of a non-point source pollution upstream that this study could not identify. Possibilities include fertilizer and animal waste in runoff from small farms, sediment runoff, or illegal discharge of wastewater of a resident in the region (Basic, 2018). This differs from Mill Creek pollution sources because Mill Creek is in an urban watershed with urban runoff polluting the stream, for instance oil, grease and toxic chemicals from motor vehicles, pesticides and nutrients from lawns and gardens (Nonpoint, 2017). Overall, the impacts of urbanization found in this study on urban streams is a rise in concentration of e. coli and a decrease in the DO. Urban growth will continue to be exacerbate the issues experienced in urban streams if the trends in land use and climate data continues as shown. 


\section{CHAPTER 6}

\section{SUMMARY, CONCLUSIONS, AND RECOMMENDATIONS}

\section{$\underline{\text { Summary and Conclusions }}$}

To identify the impacts of urbanization on the urban creek of this study, the results of the water quality tests were compared for streams in urban and rural watersheds. The results were reviewed using hydrologic and environmental factors of the region. The following is a summary of the results that demonstrate how urban land use within the watershed is impacting the urban stream of this study, Mill Creek.

- Based on the before and after data from Mill Creek, the continued urbanization of land use in the watershed is determined to be exacerbating the deterioration of the water quality of the urban stream. This is resulting in high concentrations of e. coli and low concentrations of dissolved oxygen (DO).

- Records indicate that Louisville, Kentucky has experienced high annual temperatures and precipitation volume in 2019 (NOAA, 2020).

- For parameters of $\mathrm{pH}$, water temperature, and conductivity, all creeks tested were within acceptable levels for the Kentucky Administrative regulations.

- In 2015, MSD reported that their sole monitoring location on Mill Creek found the dissolved oxygen levels were fair and rising (Parrott, 2016). It also reported fecal coliform were at good levels within the creek and staying consistent at this level (Parrott, 2016). 
- During the 2019 testing period, climate data indicates an upward trend in temperature and precipitation over the last 119 years. Increased precipitation levels were found to cause e. coli concentrations to increase the most. Durations of high temperatures and lack of precipitation were found to decrease the DO the most.

- The results found in this project for urbanizations effect on a streams water quality in an urban environment follow the same trends found in other studies. Peters and Yuan both found rises in fecal coliform concentration due to the rise of urbanization in Atlanta and China, respectively (Peters, 2009) (Yuan, 2019). Liyanage proved that increases in population in urban areas lead to a decrease in DO in urban waters (Liyanage, 2017).

- DO and e. coli concentrations out of acceptable ranges are common to the urban streams to have degradation of both, with the control creek (forested stream) only experiencing high e. coli, but acceptable levels of dissolved oxygen (DO).

- The e. coli concentration at Wilson Creek was not within Kentucky regulations and on average they were worse than most of Mill Creek (5 of 6 sites each month). While these values were higher, they were closer to Mill creek levels than Beargrass creek. The source of this contamination is a non-point source pollution of runoff, similar to Mill Creek because there are no CSOs on these creeks.

- The DO levels were acceptable on Wilson Creek, as a result of consistent flow rates and forest foliage shading for cooler water temperatures. These conditions were not found on the urban stream Mill Creek, where the water was exposed, concrete channeled, and often pooled. 
- Beargrass Creek is an urban stream that had higher e. coli concentrations on average than the Mill Creek locations. Beargrass Creek contains CSOs that contribute to e. coli concentration, where Mill Creek receives e. coli concentration pollution from surface runoff.

- Beargrass Creek DO levels were below standard, similar to Mill Creek. The values were lowest during stretches of no precipitation with increasing temperatures for both urban streams

\section{$\underline{\text { Recommendations }}$}

For water quality to improve in urban streams of this area, local solutions will need to be implemented. There are currently a limited number of monitoring stations on Mill Creek, with new projects focused on Beargrass Creek restoration. The first recommendation is to continue monitoring Mill Creek water quality to provide the data necessary for engineers to design solutions for. The next step is to present findings such as these to the Municipal companies, such as MSD, that focus on these problems. These agencies can appoint manpower and allocate funds towards restoring these creeks.

There are two concepts that could be utilized for improvement of Mill Creek without using a water treatment facility. First is a reduction in runoff from urban environments with proper storm water or sanitary management. Second would be to improve and restore shading of the creek using tree canopy coverage. Green engineering utilizing green infrastructure and sustainable developments provide these services for areas with outdated infrastructure. Many cities across the world are utilizing these practices to reduce the impact urbanization is having on the degradation of urban water 
quality (Kessler, 2011). Some examples that are recommended for Mill Creek and the urban watershed it is within are:

- Permeable Pavements: These adaptation to roads and sidewalks are designed to allow seepage of precipitation from the road level to the groundwater beneath (Performance of, 2020). This method reduces runoff from impervious surfaces and filter pollutants going through the soil beneath (Performance of, 2020). This method would require upkeep and new infrastructure construction (Performance of, 2020).

- Bioswales: Also known as vegetated swales, these trenches collect stormwater runoff and reduces the volume of it by absorbing the water for the various plants within (Performance of, 2020). They are commonly seen along roads, but can be designed for anywhere to increase biodiversity and reduce pollution form runoff volumes (Performance of, 2020).

- Urban Tree Canopy: This sustainable design is typically for downtown areas, but can be incorporated in suburban areas, as well. The technique for this solution is to expand the tree canopy into the urban areas by designating zones for tree grown or transplanting trees (Performance of, 2020). The benefits of this method would be decreases in runoff and increases in shading for cooling (performance of, 2020). The city of Louisville, KY has already begun a project called greenheart to study the health benefits of urban forestry. Expanding this canopy to areas near or on Mill Creek could reduce temperatures of the water and reduce pollutants discharged in the creek. 
- Land Conservation/ Green Spaces: This is an example of a sustainable design, rather than incorporating new green infrastructure. The idea is to allocate areas of the urban environment as green and natural spaces that cannot be developed in the future (Performance of, 2020). This land will remain in its natural form to allow runoff to seep through and reduce pollution (Performance of, 2020).

The city of Louisville is constructing a Waterway Protection Tunnel to address these urban runoff issues discharging to the urban water ways. This design will prevent "439 million gallons" a year of sewage and stormwater that would typically combine and overflow into local streams during high volume rain events (Waterway, 2019). The tunnel is built underground with a $20 \mathrm{ft}$ diameter and 4 miles in length to retain the stormwater runoff before it is sent to a treatment plant (Waterway, 2019). This project is part of MSD's consent decree plan to combat the overflow sewer designs throughout the city (Waterway, 2019). The tunnel is expected to be operational by 2021, so this new development may reduce future degradation of urban waterways degraded by urbanization. 


\section{REFERENCES}

5.9 Conductivity. (2012, March 06). Retrieved July 13, 2020, from https://archive.epa.gov/water/archive/web/html/vms59.html

Allan, J. D., \& Castillo, M. M. (2007). "Stream Ecology" (2nd ed.). New York, NY: Springer. ISBN: 978-1-4020-5582-9

About Our Agency. (2020). Retrieved July 14, 2020, from https://www.noaa.gov/about-our-agency

Basic Information about Nonpoint Source (NPS) Pollution. (2018, August 10). Retrieved July 09, 2020, from https://www.epa.gov/nps/basic-information-about-nonpoint-source-nps-pollution

Burton, T. M., \&; Hook, J. E. (2014). "Non-Point Source Pollution from Abandoned Agricultural Land in the Great Lakes Basin.” Journal of Great Lakes Research, 5(2), 99-104. doi:10.1016/s0380-1330(79)72134-4

Climate data. (2020, February 18). Retrieved July 13, 2020, from https://www.noaa.gov/topic-tags/climate-data

Combined Sewer Overflows (CSOs). (2018, August 30). Retrieved July 13, 2020, from https://www.epa.gov/npdes/combined-sewer-overflows-csos

Community and Environment. (2020). Retrieved July 13, 2020, from https://www.doh.wa.gov/CommunityandEnvironment/DrinkingWater/Contamina nts/Coliform

Conner, M. M., Saunders, W. C., Bouwes, N., \& Jordan, C. (2015). "Evaluating impacts using a BACI design, ratios, and a Bayesian approach with a focus on restoration." Environmental monitoring and assessment, 188(10), 555. https://doi.org/10.1007/s10661-016-5526-6

Consent Decree. (2005). Retrieved July 16, 2020, from https://louisvillemsd.org/consent-decree 
Córdoba, P., Cherqaoui, L., Garcia, S., \& Maroto-Valer, M. M. (2017). "Effect of Limestone and Buffer Solution in the Aqueous Speciation and $\mathrm{pH}$ of Brines for CO2 Sequestration.” Energy Procedia, 114, 4865-4871. doi:10.1016/j.egypro.2017.03.1627

Dissolved Oxygen. (2019, January 23). Retrieved July 23, 2020, from https://www.fondriest.com/environmental-measurements/parameters/waterquality/dissolved-oxygen/

Drayer, A. N., Sena, K. L., Barton, C. D., \& Andrews, D. M. (2017). "Long-Term Response of Stream and Riparian Restoration at Wilson Creek, Kentucky USA". Ecological Restoration, 35(3), 246-254. doi:10.3368/er.35.3.246

Dunbar, B. (2015, May 13). "What Is Climate Change?” Retrieved July 06, 2020, from https://www.nasa.gov/audience/forstudents/k-4/stories/nasa-knows/what-isclimate-change-k4.html

Englebert, E. T., Mcdermott, C., \& Kleinheinz, G. T. (2008). "Effects of the nuisance algae, Cladophora, on Escherichia coli at recreational beaches in Wisconsin". Science of The Total Environment, 404(1), 10-17. doi:10.1016/j.scitotenv.2008.05.025

Fant, C., Srinivasan, R., Boehlert, B., Rennels, L., Chapra, S., Strzepek, K., Martinich, J. (2017). "Climate Change Impacts on US Water Quality Using Two Models: HAWQS and US Basins”. Water, 9(2), 118. doi:10.3390/w9020118

Filtration-apparatus. (2020). Retrieved July 20, 2020, from https://www.toptionlab.com/lab-filtration-apparatus/1000-filtrationapparatus.html

The Fundamentals of the Water Cycle. (1993). Retrieved July 09, 2020, from https://www.usgs.gov/special-topic/water-science-school/science/fundamentalswater-cycle?qt-science_center_objects $=0$

Gullapalli, V. D. (2008). Stream Flow Augmentation Using Treated Filter Wash Water [Master of Science]. University of Louisville.

Haack, S. (2017, January 4). "Fecal Indicator Bacteria and Sanitary Water Quality." Retrieved July 13, 2020, from https://mi.water.usgs.gov/h2oqual/BactHOWeb.html 
Hamid, A., Bhat, S.U. \& Jehangir, A. "Local determinants influencing stream water Quality". Appl Water Sci 10, 24 (2020). https://doi.org/10.1007/s13201-0191043-4

Heat Island Impacts. (2020, July 29). Retrieved October 02, 2020, from https://www.epa.gov/heatislands/heat-island-impacts

Henry, G., \& Heinke, G. W. (1996). "Environmental science and engineering" (2nd ed.). Englewood Cliffs, NJ: Prentice-Hall. ISBN: 0-13-1260650-8

Hilborn, E. D., Roberts, V. A., Backer, L., Deconno, E., Egan, J. S., Hyde, J. B., Nicholas, D. C., Wiegert, E. J., Billing, L. M., Diorio, M., Mohr, M. C., Hardy, J. F., Wade, T. J., Yoder, J. S., Hlavsa, M. C., \& Centers for Disease Control and Prevention (CDC) (2014). Algal bloom-associated disease outbreaks among users of freshwater lakes--United States, 2009-2010. MMWR. Morbidity and mortality weekly report, 63(1), 11-15.

Jalliffier-Verne, I., Leconte, R., Huaringa-Alvarez, U., Heniche, M., Madoux-Humery, A., Autixier, L., \& Dorner, S. (2017). "Modelling the impacts of global change on concentrations of Escherichia coli in an urban river". Advances in Water Resources, 108, 450-460. doi:10.1016/j.advwatres.2016.10.001

Kentucky Energy and Environment Cabinet. (2020). Retrieved July 14, 2020, from https://eec.ky.gov/Environmental-Protection/Water/Pages/default.aspx

Kentucky General Assembly. (2020). Retrieved July 14, 2020, from https://legislature.ky.gov/Law/kar/Pages/default.aspx

Kessler, R. (2011). "Stormwater Strategies: Cities Prepare Aging Infrastructure for Climate Change." Environmental Health Perspectives, 119(12). doi:10.1289/ehp.119-a514

Kolbe, K. (2019, May 08). Mitigating urban heat island effect and carbon dioxide emissions through different mobility concepts: Comparison of conventional vehicles with electric vehicles, hydrogen vehicles and public transportation. Retrieved October 08, 2020, from https://www.sciencedirect.com/science/article/pii/S0967070X17308478

Kumar, P., Dasgupta, R., Ramaiah, M., Avtar, R., Johnson, B. \&; Mishra, B. (2019). "Hydrological Simulation for Predicting the Future Water Quality of Adyar River, Chennai, India." International Journal of Environmental Research and Public Health, 16(23), 4597. doi:10.3390/ijerph16234597 
Lim, J. Y., Yoon, J., \&; Hovde, C. J. (2010). "A Brief Overview of Escherichia coli O157:H7 and Its Plasmid O157." Journal of Microbiology and Biotechnology, 20(1), 5-14. doi:10.4014/jmb.0908.08007

Liyanage, C. P., \&; Yamada, K. (2017, August 09). Impact of Population Growth on the Water Quality of Natural Water Bodies. Retrieved October 16, 2020, from https://ideas.repec.org/a/gam/jsusta/v9y2017i8p1405-d107684.html

Long, A. M., Colón, M. R., Bosman, J. L., Robinson, D. H., Pruett, H. L., McFarland, T. M., Mathewson, H. A., Szewczak, J. M., Newnam, J. C., \& Morrison, M. L. (2017). "A before-after control-impact assessment to understand the potential impacts of highway construction noise and activity on an endangered songbird." Ecology and evolution, 7(1), 379-389. https://doi.org/10.1002/ece3.2608

Louisville and Jefferson County Wet Weather Consent Decree Quarterly Report (55th ed., pp. 1-200, Rep. No. 55). (2019). Louisville, KY: Louisville and Jefferson County Metropolitan Sewer District.

Louisville and Jefferson County Wet Weather Consent Decree Quarterly Report (56th ed., pp. 1-158, Rep. No. 56). (2019). Louisville, KY: Louisville and Jefferson County Metropolitan Sewer District.

“Louisville MSD Watershed Master Plan” (pp. 1-116, Rep.). (2017). Louisville, KY: MSD.

Marsh, G., \& Fairbridge, R. (1999, January 01). Lentic and lotic ecosystems. Retrieved July 13, 2020, from https://ink.springer.com/referenceworkentry/10.1007/1-4020-4494-1_204

Michalak, A. M. (2016). "Study role of climate change in extreme threats to water quality.” Nature, 535(7612), 349-350. doi:10.1038/535349a

Miller, J. \& Hutchins, M. (2017, July 08). "The impacts of urbanisation and climate change on urban flooding and urban water quality: A review of the evidence concerning the United Kingdom." Retrieved July 09, 2020, from https://www.sciencedirect.com/science/article/pii/S2214581817300435

Miranda, L., Hargreaves, J. \& Raborn, S. Predicting and managing risk of unsuitable dissolved oxygen in a eutrophic lake. Hydrobiologia 457, 177-185 (2001). https://doi.org/10.1023/A:1012283603339 
Mohajerani, A., Bakaric, J., \&amp; Jeffrey-Bailey, T. (2017). The urban heat island effect, its causes, and mitigation, with reference to the thermal properties of asphalt concrete. Journal of Environmental Management, 197, 522-538. doi:10.1016/j.jenvman.2017.03.095

Mohammed, H., Longva, A., \& Seidu, R. (2018). "Impact of climate forecasts on the microbial quality of a drinking water source in Norway using hydrodynamic modelling." Hydrology and Earth System Sciences Discussions, 1-20. doi:10.5194/hess-2018-488

MSD CSO/SSO Locations. Retrieved October 06, 2020, from https://apps.lojic.org/msdcsossolocations/

Nedeau, E. J., Merritt, R. W., \&; Kaufman, M. G. (2003). "The effect of an industrial effluent on an urban stream benthic community: Water quality vs. habitat quality." Environmental Pollution, 123(1), 1-13. doi:10.1016/s02697491(02)00363-9

NOAA National Centers for Environmental information, Climate at a Glance: County Time Series, published July 2020, retrieved on July 1, 2020 from https://www.ncdc.noaa.gov/cag/

Nonpoint Source: Urban Areas. (2017, March 31). Retrieved July 09, 2020, from https://www.epa.gov/nps/nonpoint-source-urban-areas

NPDES Permit Basics. (2019, July 12). Retrieved July 14, 2020, from https://www.epa.gov/npdes/npdes-permit-basics

Odonkor, Stephen T., and Ampofo, Joseph K.. "Escherichia Coli as an Indicator of Bacteriological Quality of Water: an Overview." Microbiology Research, vol. 4, no. 1, 2013, p. 2., doi:10.4081/mr.2013.e2.

Oshiro, R. K. (2002). Method 1604: Total coliforms and Escherichia coli in water by membrane filtration using a simultaneous detection technique (MI Medium) (pp. 1-12) (United States, Environmental Protection Agency, Water (4303T)). Washington, DC: USEPA.

Our Mission and What We Do. (2018, February 07). Retrieved July 14, 2020, from https://www.epa.gov/aboutepa/our-mission-and-what-we-do

Parrott, James A. MSD, 2016, "State of the Streams 2016 Water Quality Synthesis Report", https://louisvillemsd.org/sites/default/files/file_repository/2016\%20Synthesis $\% 20$ Report\%20pages\%20FINAL.pdf. 
Performance of Green Infrastructure. (2020, April 09). Retrieved July 26, 2020, from https://www.epa.gov/green-infrastructure/performance-green-infrastructure

Peters, N. E. (2009). "Effects of urbanization on stream water quality in the city of Atlanta, Georgia, USA.” Hydrological Processes, 23(20), 2860-2878. doi:10.1002/hyp.7373

PH and Water. (2002). Retrieved July 22, 2020, from https://www.usgs.gov/special-topic/water-science-school/science/ph-andwater?qt-science_center_objects $=0$

Philipsborn, R., Ahmed, S. M., Brosi, B. J., \& Levy, K. (2016). “Climatic Drivers of Diarrheagenic Escherichia coli Incidence: A Systematic Review and Metaanalysis." The Journal of infectious diseases, 214(1), 6-15. https://doi.org/10.1093/infdis/jiw081

Pires, N., Muniz, D., Kisaka, T., Simplicio, N., Bortoluzzi, L., Lima, J., \& OliveiraFilho, E. (2015). "Impacts of the Urbanization Process on Water Quality of Brazilian Savanna Rivers: The Case of Preto River in Formosa, Goiás State, Brazil.” International Journal of Environmental Research and Public Health, 12(9), 10671-10686. doi:10.3390/ijerph120910671

Sanitary Sewer Overflows (SSOs). (2016, November 01). Retrieved July 13, 2020, from https://www.epa.gov/npdes/sanitary-sewer-overflows-ssos

Smith, E.P. (2002). BACI Design. A.H. El-Shaarawi \& W. W. Piegorsch. In Encyclopedia of Environmetrics. Retrieved from John Wiley \& Sons.

Somers, K. A., Bernhardt, E. S., Mcglynn, B. L., Urban, D. L. (2016).

"Downstream Dissipation of Storm Flow Heat Pulses: A Case Study and its Landscape-Level Implications.” JAWRA Journal of the American Water Resources Association, 52(2), 281-297. doi:10.1111/1752-1688.12382

Summary of the Clean Water Act. (2019, March 11). Retrieved July 14, 2020, from https://www.epa.gov/laws-regulations/summary-clean-water-act

Thomann, R. V., \& Mueller, J. A. (1993). "Principles of surface water quality modeling and control”. New York, NY: Harper Collins. ISBN: 0-06-046677-4

Urban Storm Water BMP Preliminary Data Summary. (1999). Retrieved July 9, 2020, from https://www3.epa.gov/npdes/pubs/usw_a.pdf 
Urbanization and Water Quality, 2020, www.usgs.gov/special-topic/water-scienceschool/science/urbanization-and-water-quality?qt-science_center_objects $=0$.

U.S. Census Bureau QuickFacts: Louisville/Jefferson County (balance), Kentucky. (July $\left.1^{\text {st }}, 2019\right)$. Retrieved October 16, 2020, from https://www.census.gov/quickfacts/fact/table/louisvillejeffersoncountybalanceken tucky/PST045219

U.S. Energy Information Administration - EIA - Independent Statistics and Analysis. (2017). Retrieved July 08, 2020, from https://www.eia.gov/energyexplained/energy-and-the-environment/wheregreenhouse-gases-come-from.php

U.S. EPA. 2019. "Inventory of U.S. Greenhouse Gas Emissions and Sinks: 1990 - 2017.Office of Atmospheric Programs, U.S. Environmental Protection Agency." EPA 430-R19-001. Available: https://www.epa.gov/ghgemissions/inventory-us-greenhouse-gasemissions-andsinks-1990-2017.

USGS 03294570 MILL CREEK AT ORELL ROAD NEAR LOUISVILLE, KY. (2019, July 17). Retrieved July 17, 2019, from https://waterdata.usgs.gov/ky/nwis/uv/?site_no $=03294570$

USGS Water-Quality Data for the Nation. (2020). Retrieved July 13, 2020, from https://waterdata.usgs.gov/nwis/qw

Viessman, W., Jr., Hammer, M. J., Perez, E. M., and Chadik, P. A. (2015). "Water supply and Pollution Control" (8th ed.). Upper Saddle River, NJ: Pearson India Education. ISBN:0-13-233717-7

Water Quality. (2016).MSD. Retrieved July 01, 2020, from https://louisvillemsd.org/WaterQuality

"WATERS of Jefferson County - Year Zero" (Mill Creek Watershed, pp. 179-198, Rep.). (1999, December 20). Louisville, KY: MSD

Waterway Protection Tunnel. (March, 2019). Retrieved October 16, 2020, from http://www.louisvillemsd.org/tunnel

WIN, P. Project WIN Consent Decree Library. Retrieved October 06, 2020, from http://www.msdprojectwin.org/Library.aspx 
Yuan, T., Vadde, K. K., Tonkin, J. D., Wang, J., Lu, J., Zhang, Z., . . Sekar, R. (2019). Urbanization Impacts the Physicochemical Characteristics and Abundance of Fecal Markers and Bacterial Pathogens in Surface Water. International Journal of Environmental Research and Public Health, 16(10), 1739.

doi:10.3390/ijerph16101739 


\section{APPENDIX A}

\section{Unit Conversions}

\section{Temperature:}

Fahrenheit $\left({ }^{\circ} \mathrm{F}\right)={ }^{\circ} \mathrm{C}(9 / 5)+32$

Celsius $\left({ }^{\circ} \mathrm{C}\right)=\left({ }^{\circ} \mathrm{F}-32\right)-(5 / 9)$

Flow:

1 million gallon per day $(\mathrm{MGD})=1.547$ cubic feet per second

1 cubic feet per second $(\mathrm{CFS})=0.646$ million gallon per day

\section{Conductivity:}

1 micro Siemens per centimeter $(\mu \mathrm{S} / \mathrm{cm})=1$ micromho per centimeter $(\mu \mathrm{mho} / \mathrm{cm})$

\section{Concentration:}

1 part per million $(\mathrm{ppm})=1$ milligram per liter $(\mathrm{mg} / \mathrm{L})$ 


\section{APPENDIX B}

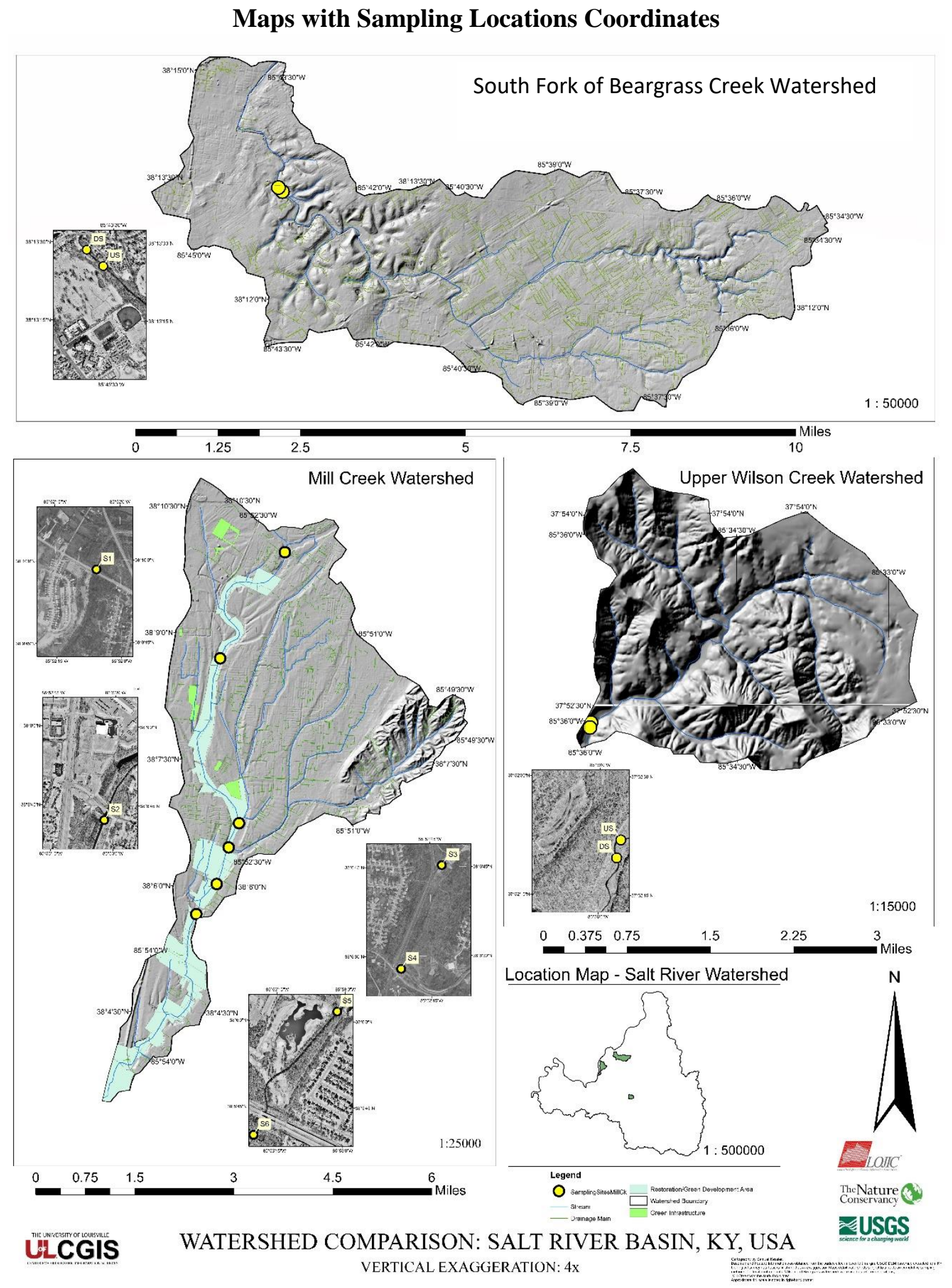




\section{Mill Creek Sampling Locations Coordinates}

\begin{tabular}{|r|r|r|l|}
\hline $\begin{array}{c}\text { Mill Creek } \\
\text { Site }\end{array}$ & Latitude & \multicolumn{1}{|l|}{ Longitude } & \multicolumn{1}{|c|}{ Nickname } \\
\hline 1 & 38.166178 & -85.868164 & Lower Hunters Trace \\
\hline 2 & 38.145210 & -85.883923 & Greenwood Drive \\
\hline 3 & 38.112560 & -85.878566 & Black Pond Creek Confluence \\
\hline 4 & 38.107784 & -85.881023 & Ashby Lane \\
\hline 5 & 38.100543 & -85.883772 & Bethany Lane \\
\hline 6 & 38.078124 & -85.889784 & W Orell Road \\
\hline
\end{tabular}

\section{Beargrass Creek and Wilson Creek Sampling Locations Coordinates}

\begin{tabular}{|l|l|r|l|r|r|}
\hline $\begin{array}{c}\text { Beargrass } \\
\text { Creek }\end{array}$ & Latitude & \multicolumn{1}{|c|}{ Longitude } & $\begin{array}{c}\text { Wilson Creek } \\
\text { Sites }\end{array}$ & Latitude & \multicolumn{1}{c|}{ Longitude } \\
\hline Upstream & 38.224717 & -85.726976 & Upstream & 37.870192 & -85.59987 \\
\hline Downstream & 38.224622 & -85.726872 & Downstream & 37.870076 & -85.599833 \\
\hline
\end{tabular}




\section{APPENDIX C}

Mill Creek Precipitation Events Calendar (NOAA, 2020)

\begin{tabular}{|c|c|c|c|c|c|c|}
\hline \multicolumn{7}{|c|}{ Mill Creek } \\
\hline \multicolumn{7}{|c|}{ July 2019} \\
\hline Sunday & Monday & Tuesday & Wednesday & Thursday & Friday & Saturday \\
\hline & 1 & 2 & 3 & 4 & 5 & 6 \\
\hline 7 & 8 & 9 & 10 & 11 & 12 & 13 \\
\hline 14 & 15 & 16 & 17 & 18 & 19 & $\underline{20}$ \\
\hline 21 & $\underline{22}$ & 23 & $\underline{24}$ & 25 & 26 & $\underline{27}$ \\
\hline 28 & 29 & $\underline{\underline{30}}$ & $\underline{31}$ & & & \\
\hline \multicolumn{7}{|c|}{ August 2019} \\
\hline Sunday & Monday & Tuesday & Wednesday & Thursday & Friday & Saturday \\
\hline & & & & 1 & $\underline{2}$ & 3 \\
\hline 4 & $\underline{5}$ & 6 & $\underline{7}$ & 8 & 9 & $\underline{10}$ \\
\hline 11 & 12 & 13 & $\underline{14}$ & 15 & 16 & $\underline{17}$ \\
\hline 18 & 19 & 20 & 21 & 22 & 23 & 24 \\
\hline 25 & 26 & 27 & 28 & 29 & 30 & 31 \\
\hline
\end{tabular}

Dates in blue indicate precipitation events, underlined indicate testing days 


\section{APPENDIX D}

\section{NOAA Data Table for Total Precipitation in Mill Creek for July-August, 2019}

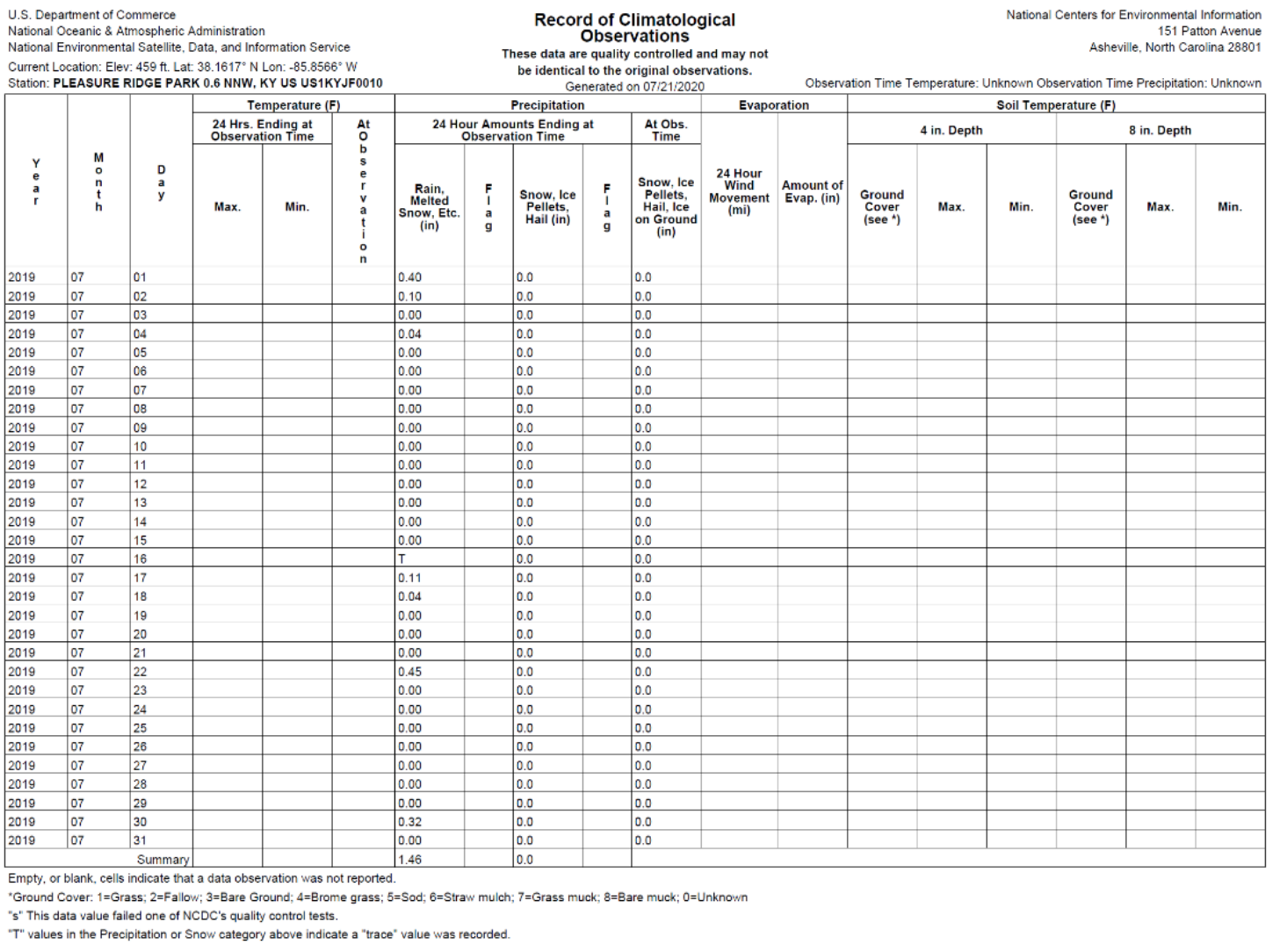




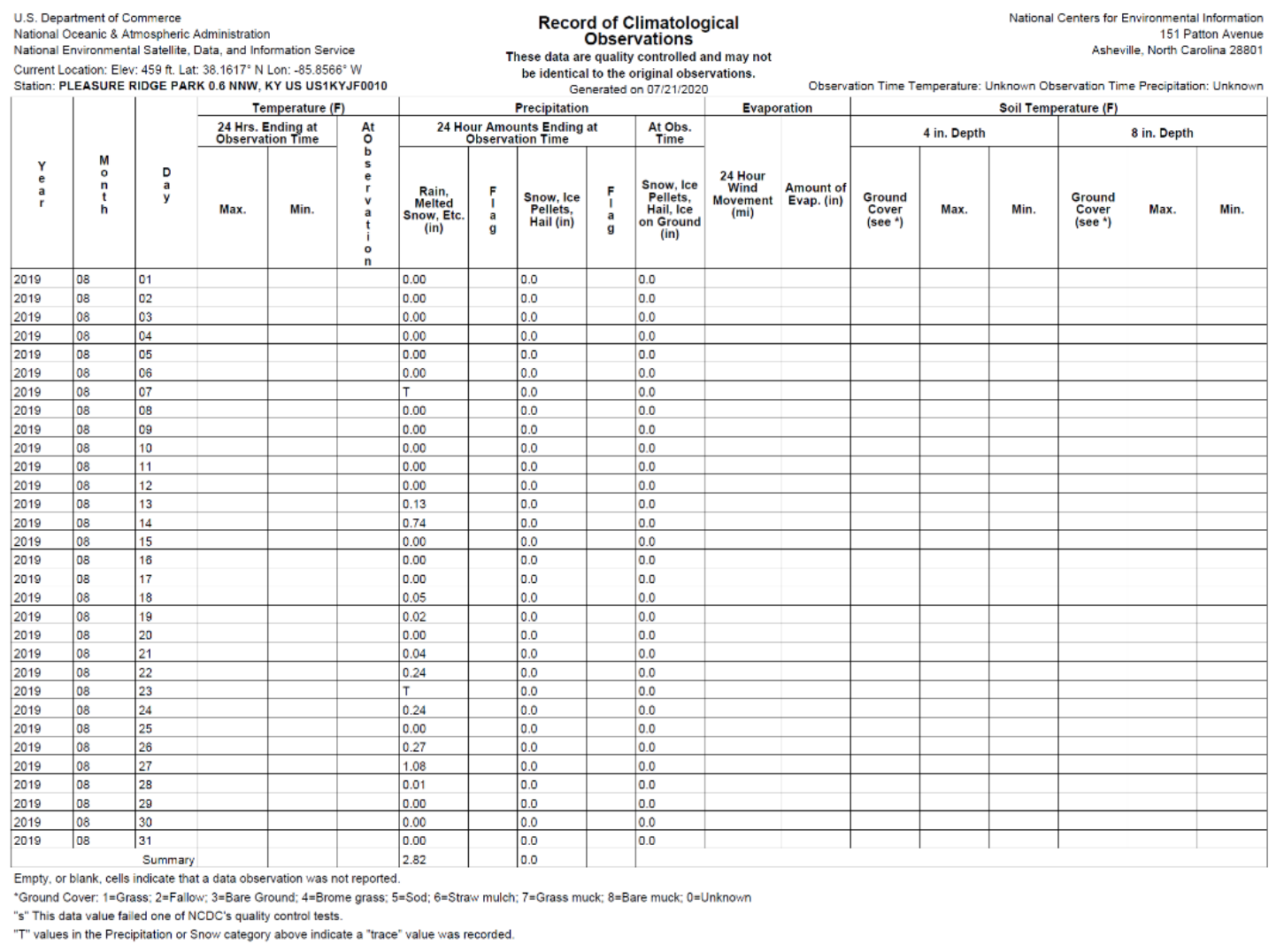




\section{APPENDIX E}

\section{Climate Trends for Jefferson County and The Greater Midwest Region}

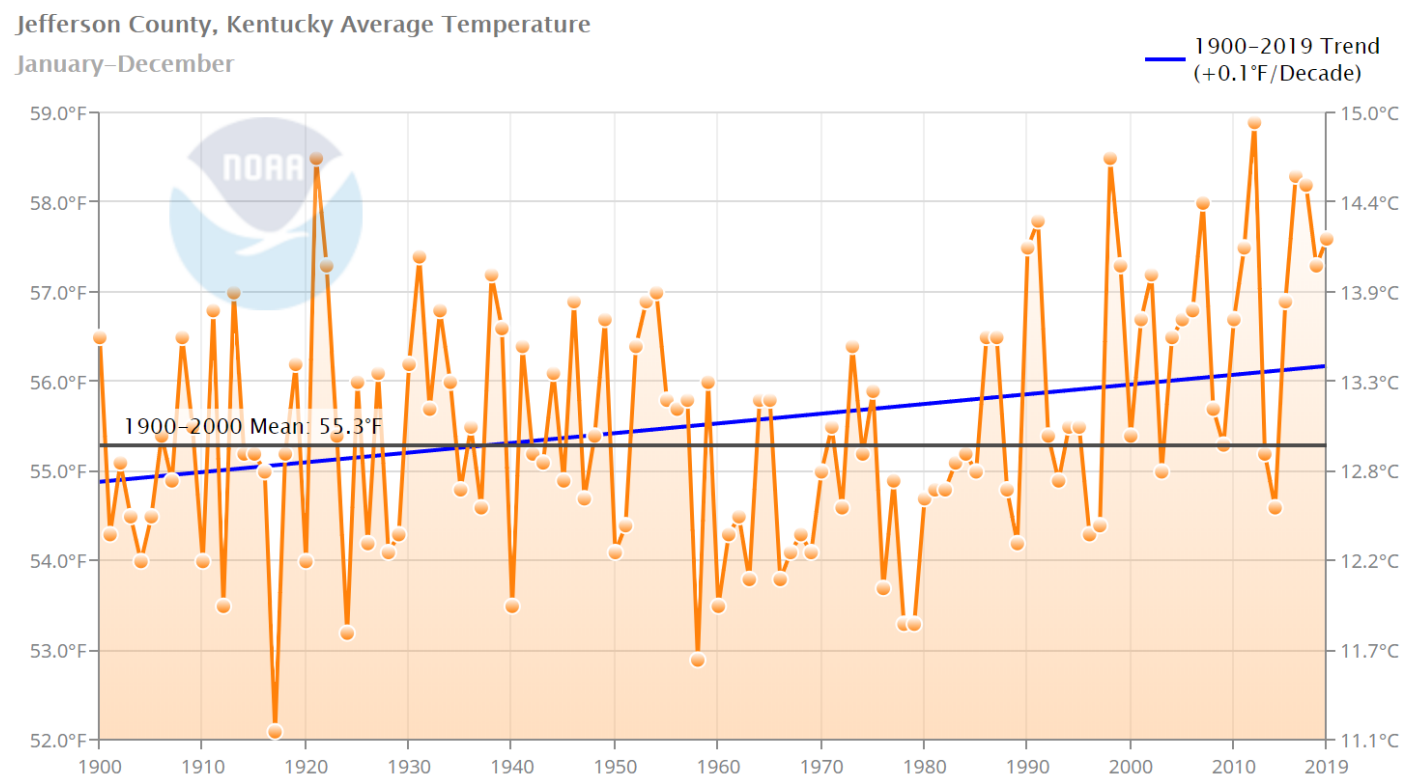

Jefferson County Average Annual Atmospheric Temperature (1900-2019) (NOAA, 


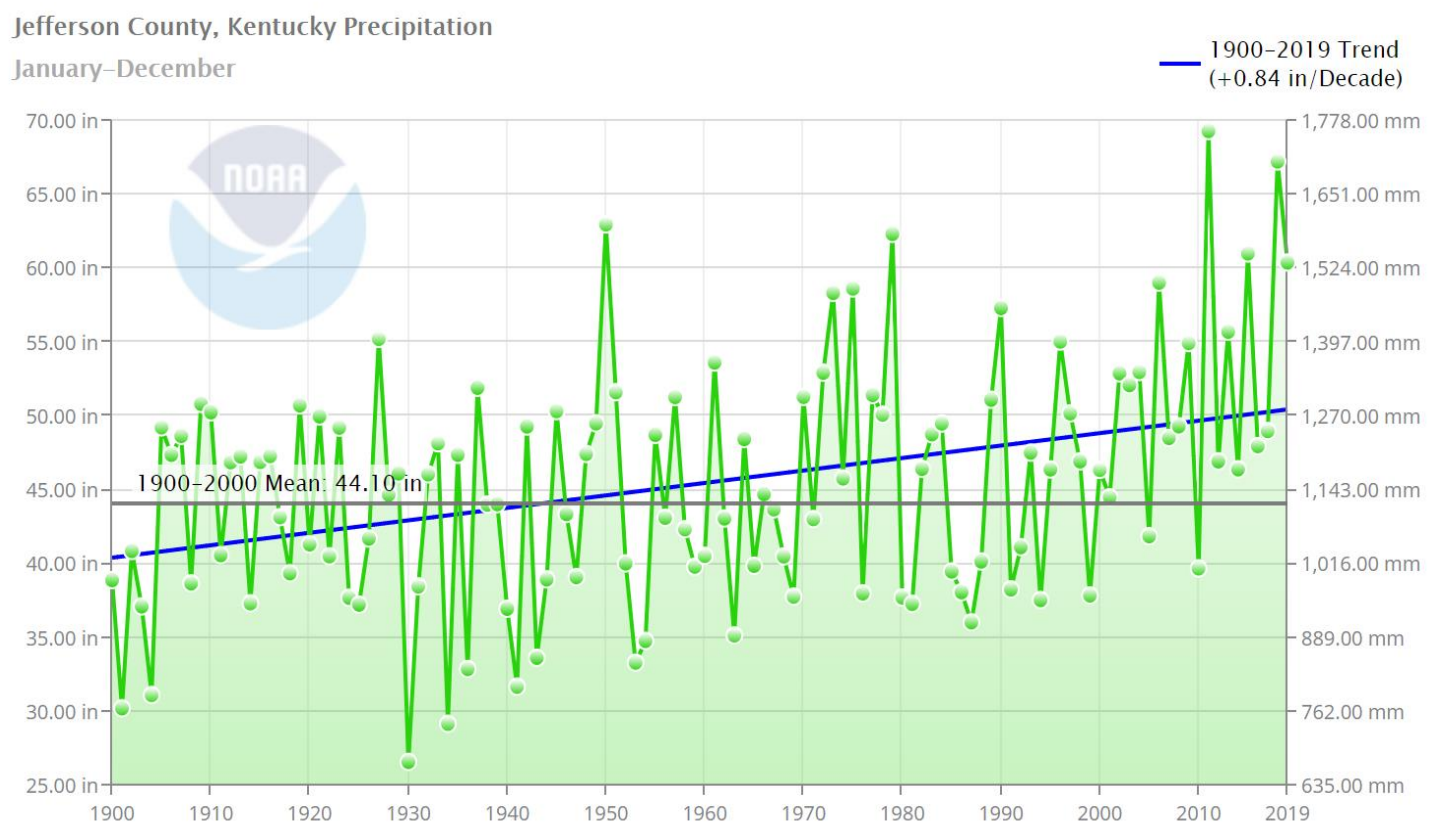

Jefferson County Annual Precipitation levels (1900-2019) (NOAA, 2020)

Ohio Valley Extremes in 1-Day Precipitation (Step 4*)

Annual (January-December)

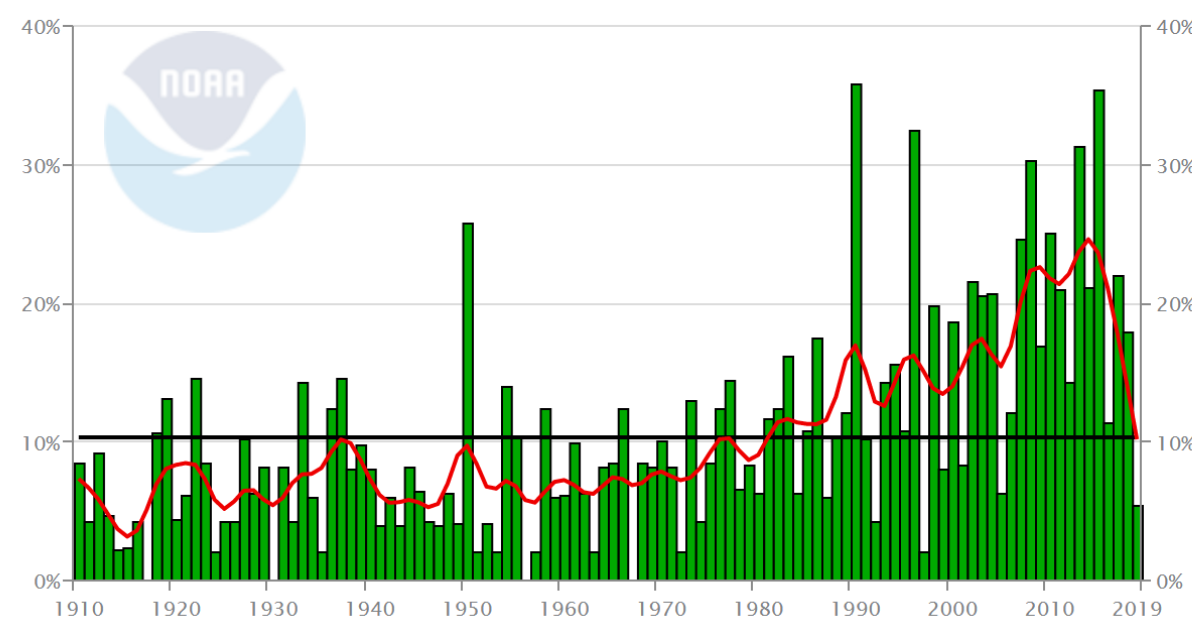

Ohio River Valley Extremes in 1-Day Precipitation (1910-2019) (NOAA, 2020) 
Ohio Valley Palmer Drought Severity Index (PDSI)

_ 1900-2019 Trend

(+0.14/Decade)

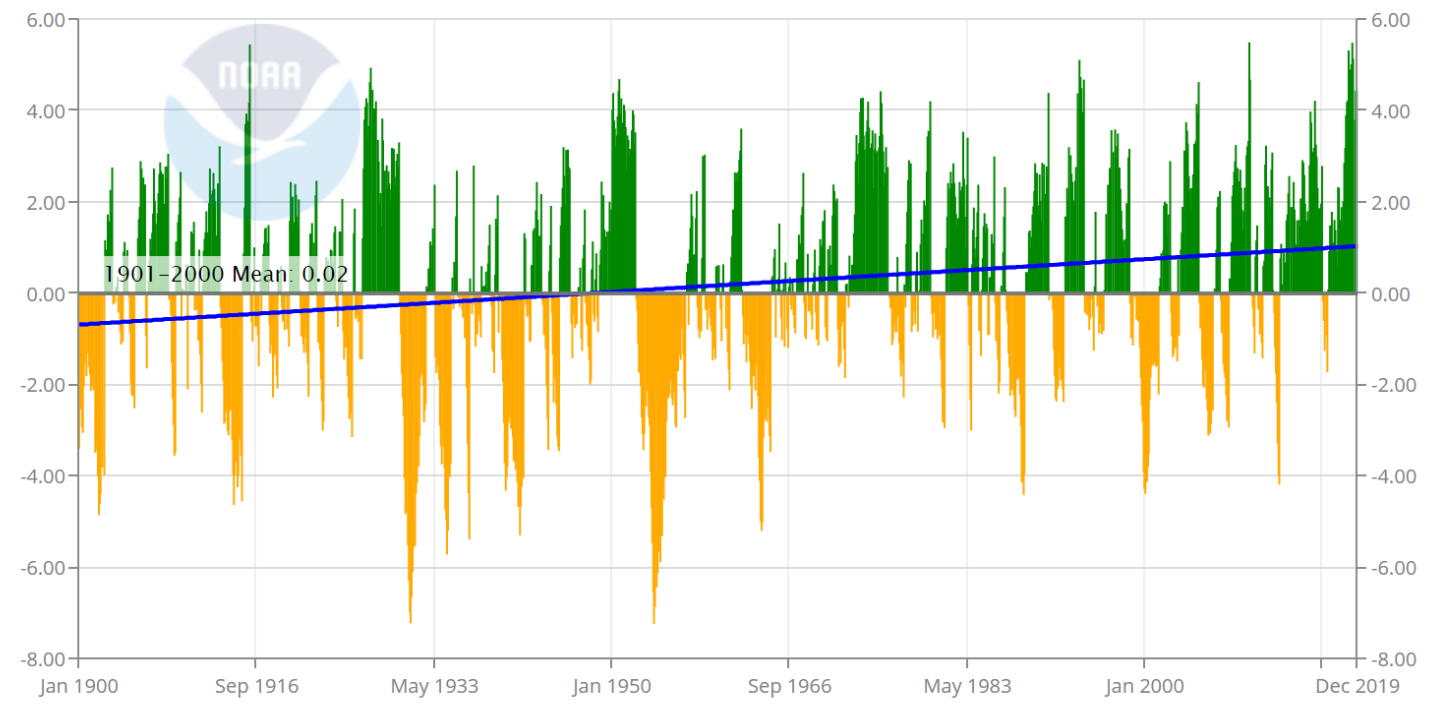

Ohio River Valley PDSI (1900-2019) (NOAA, 2020) 


\section{APPENDIX F}

\section{Project Photographs}

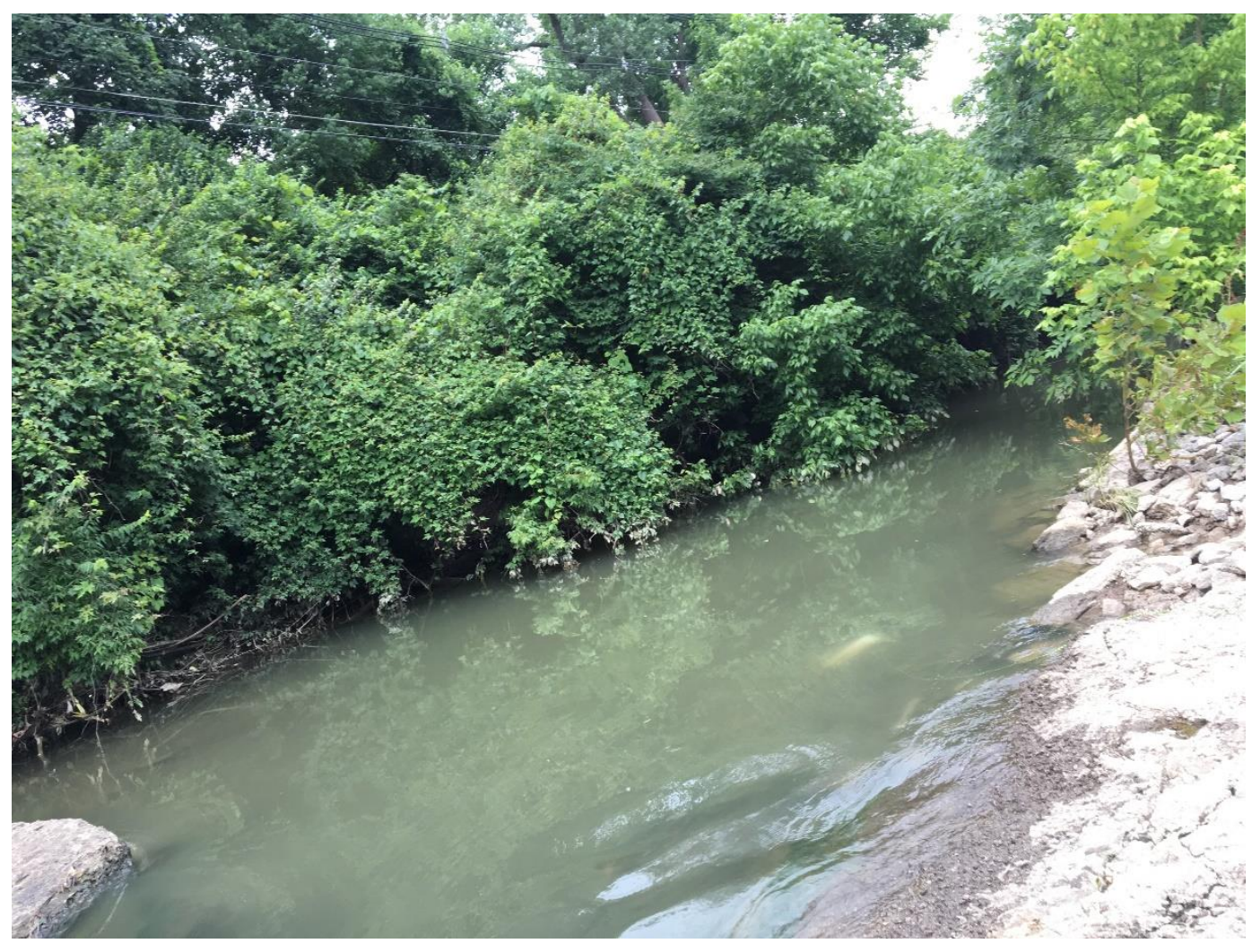

South Fork Beargrass Creek upstream sampling location 


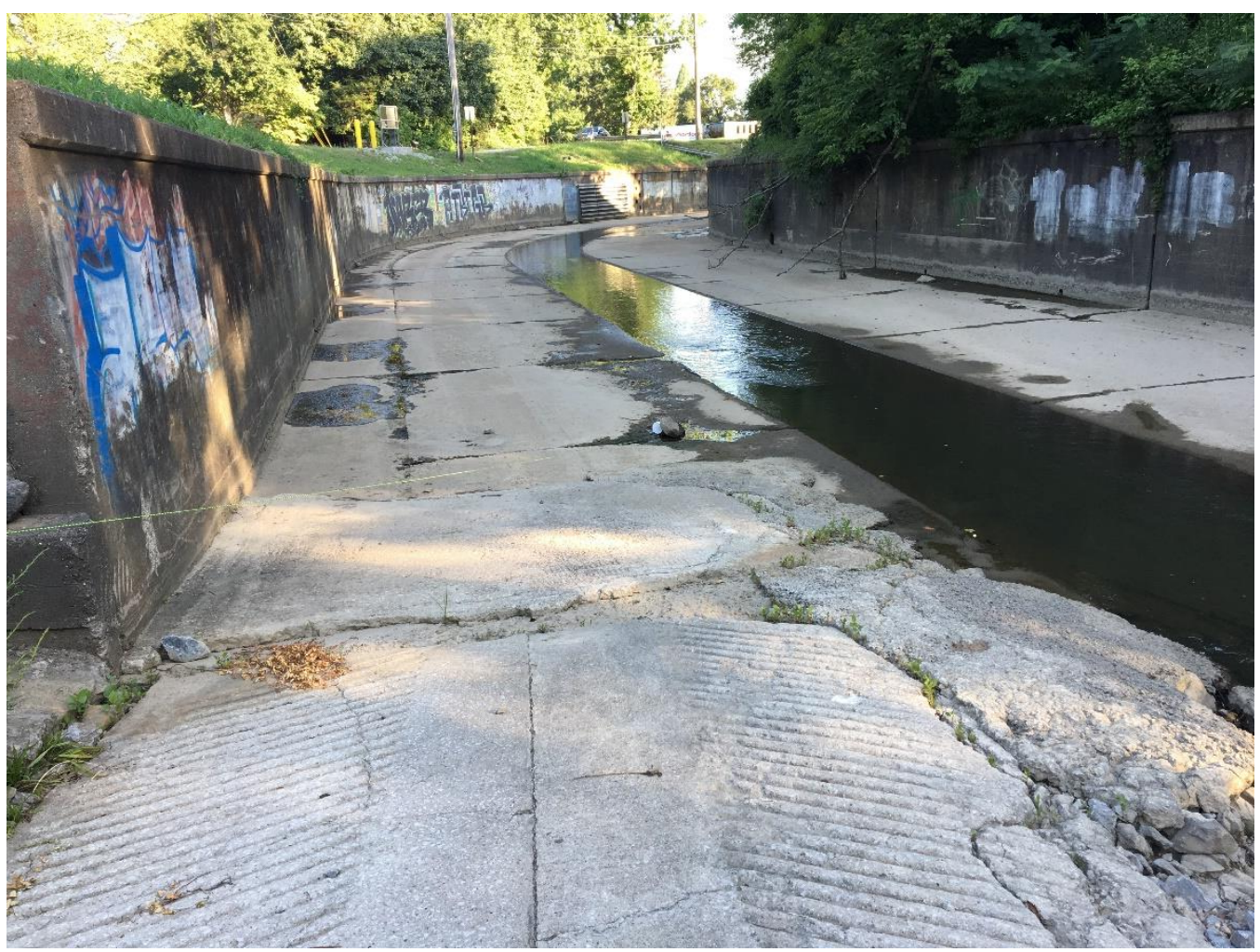

South Fork Beargrass Creek downstream sampling location 


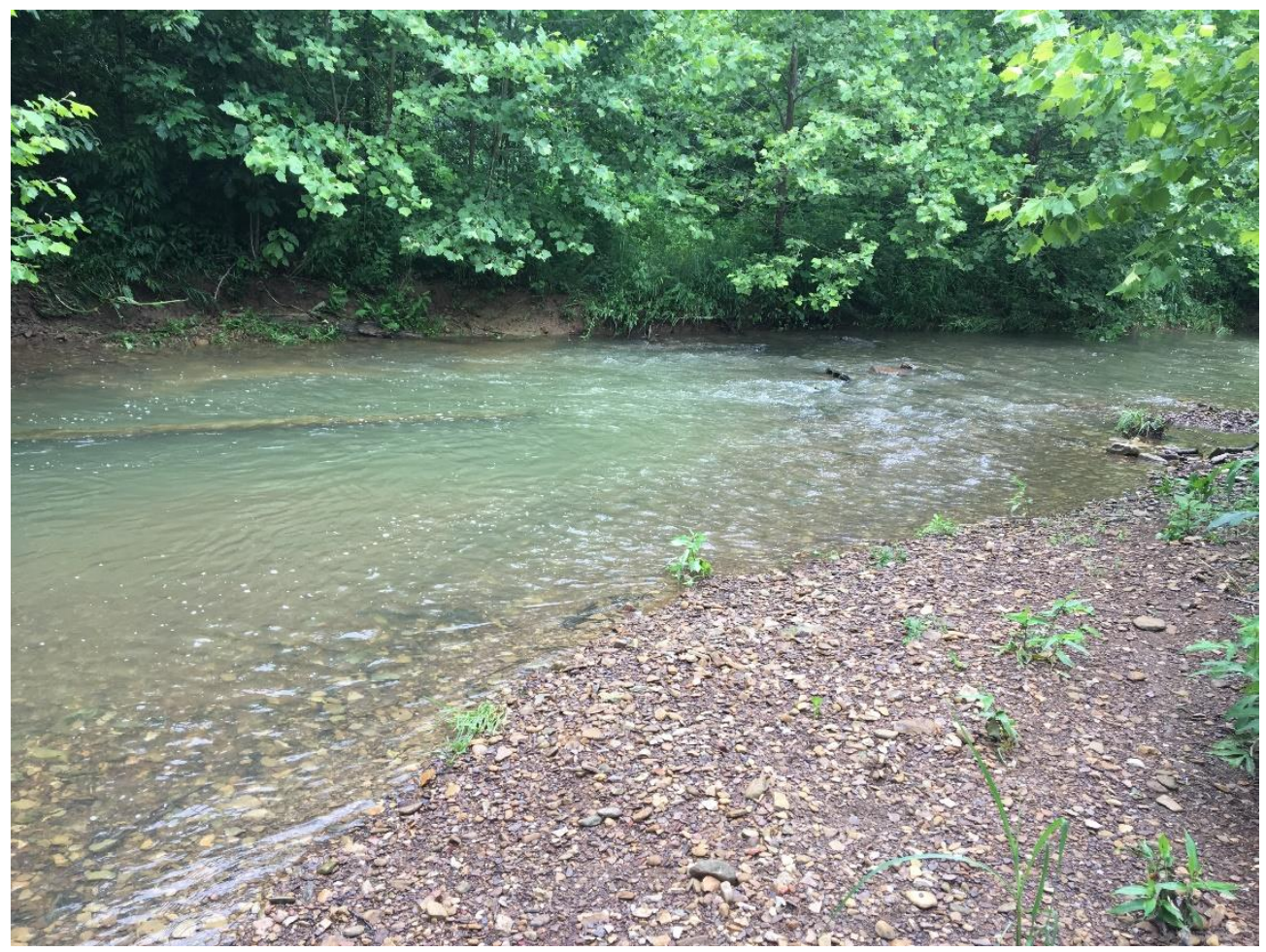

Wilson Creek upstream sampling location

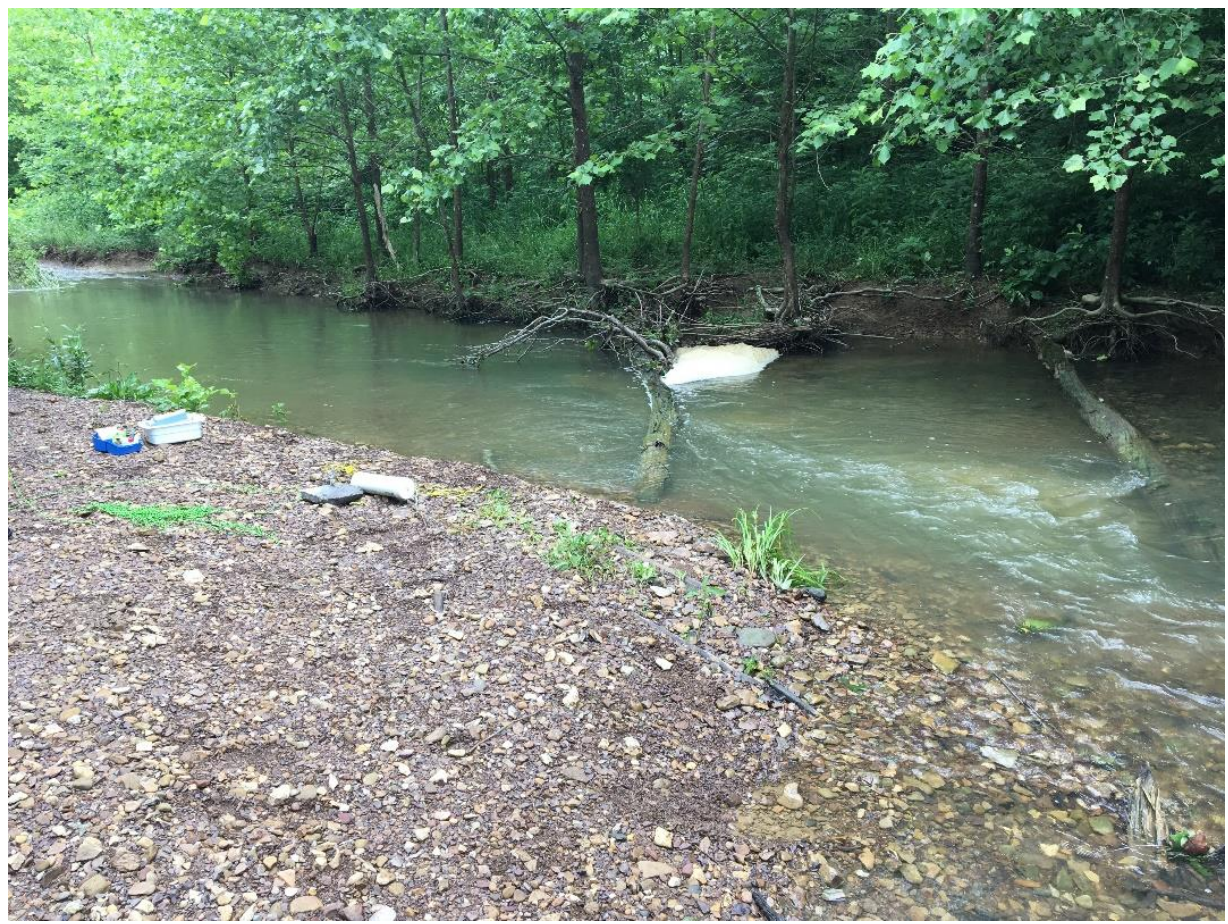

Wilson Creek downstream sampling location 


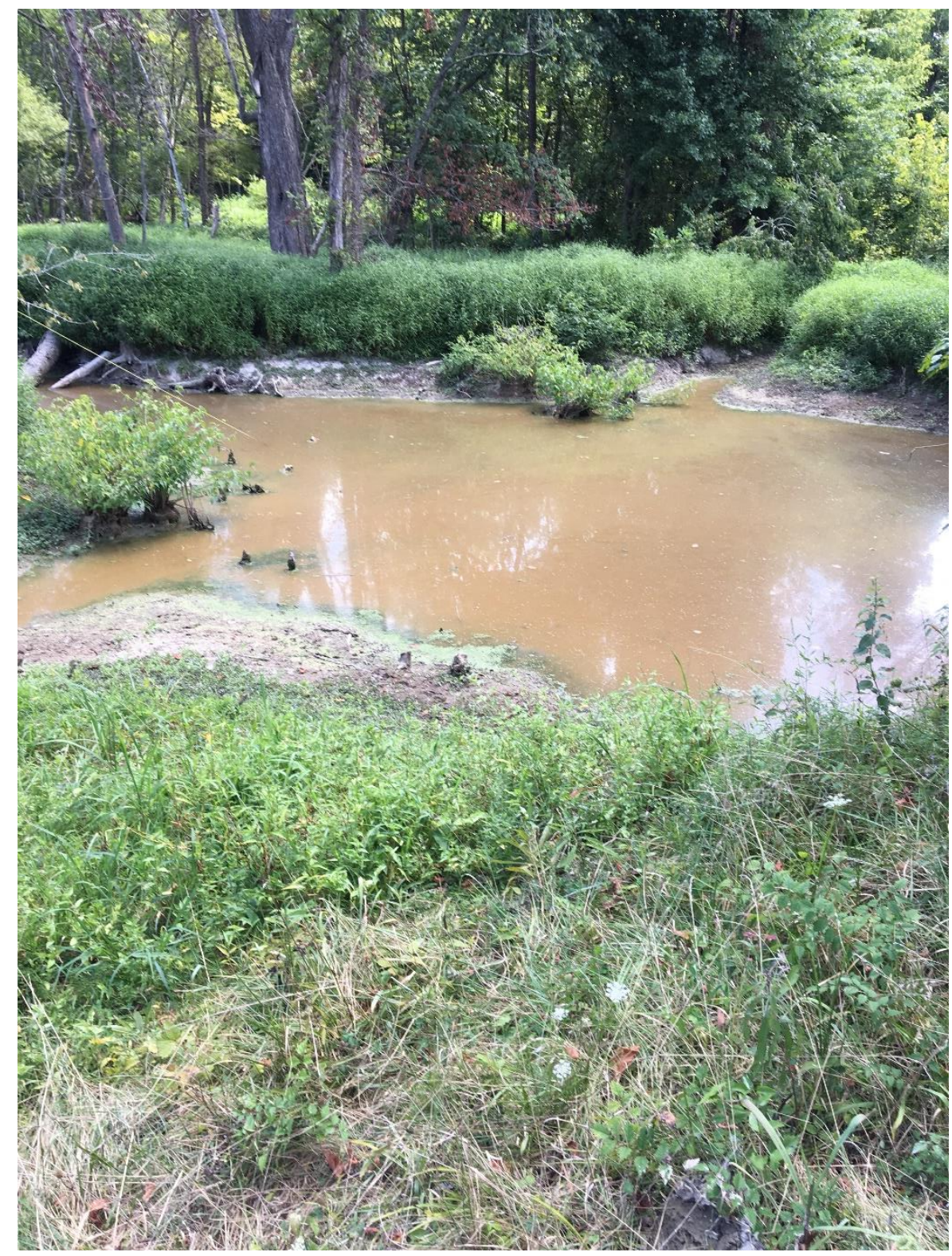

Mill Creek site 1 sampling location 


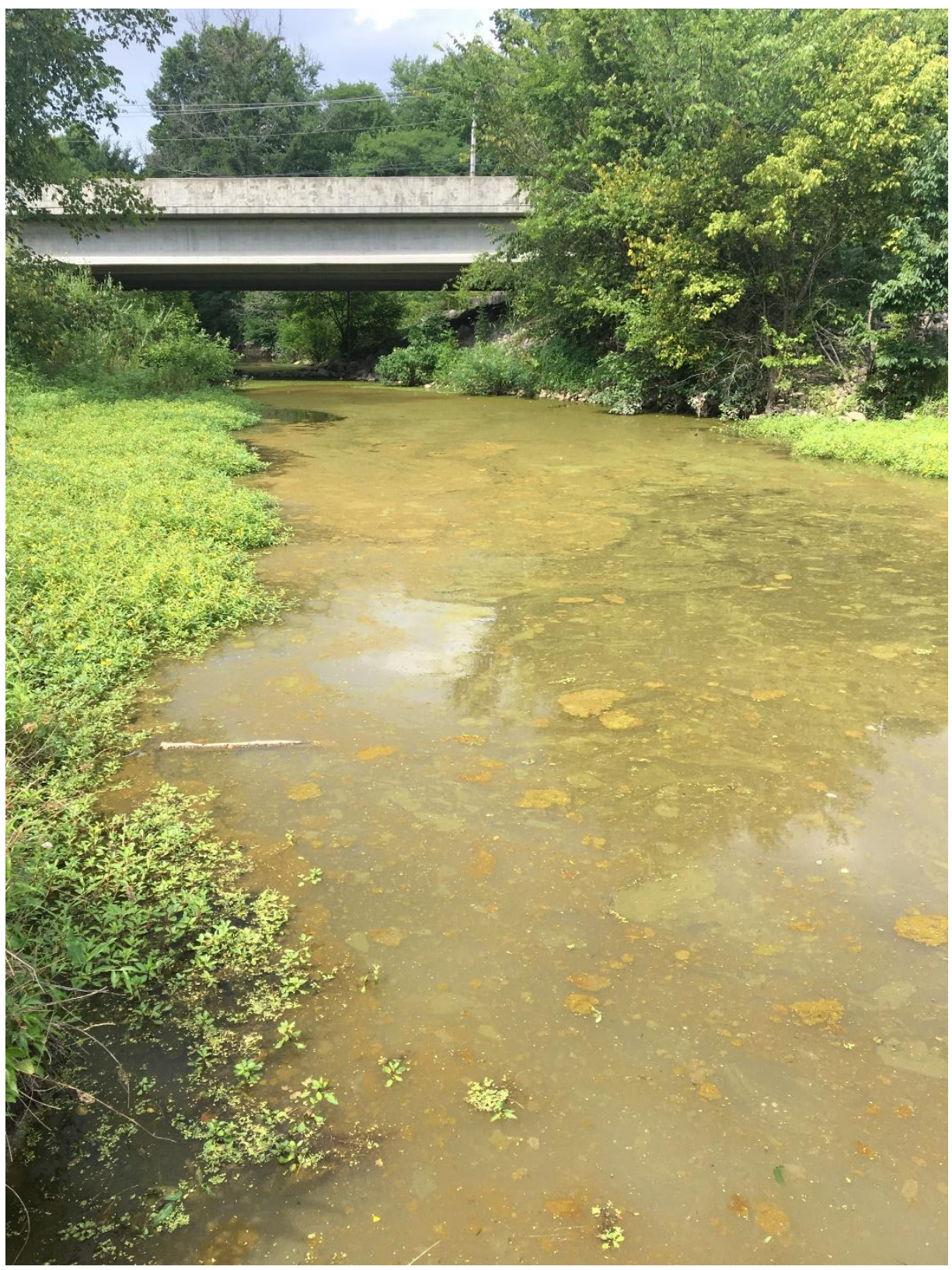

Mill Creek site 2 sampling location 


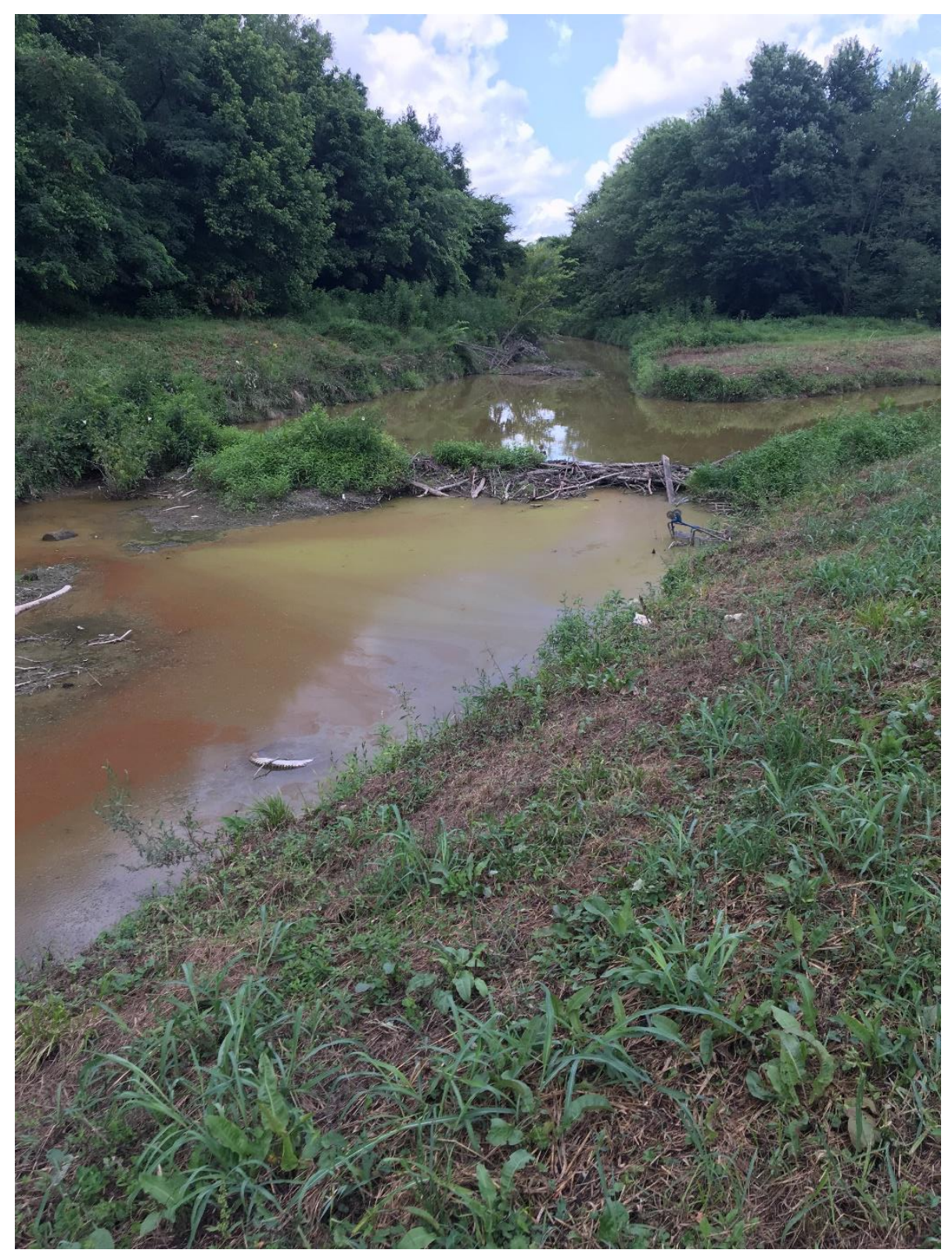

Mill Creek site 3 sampling location 


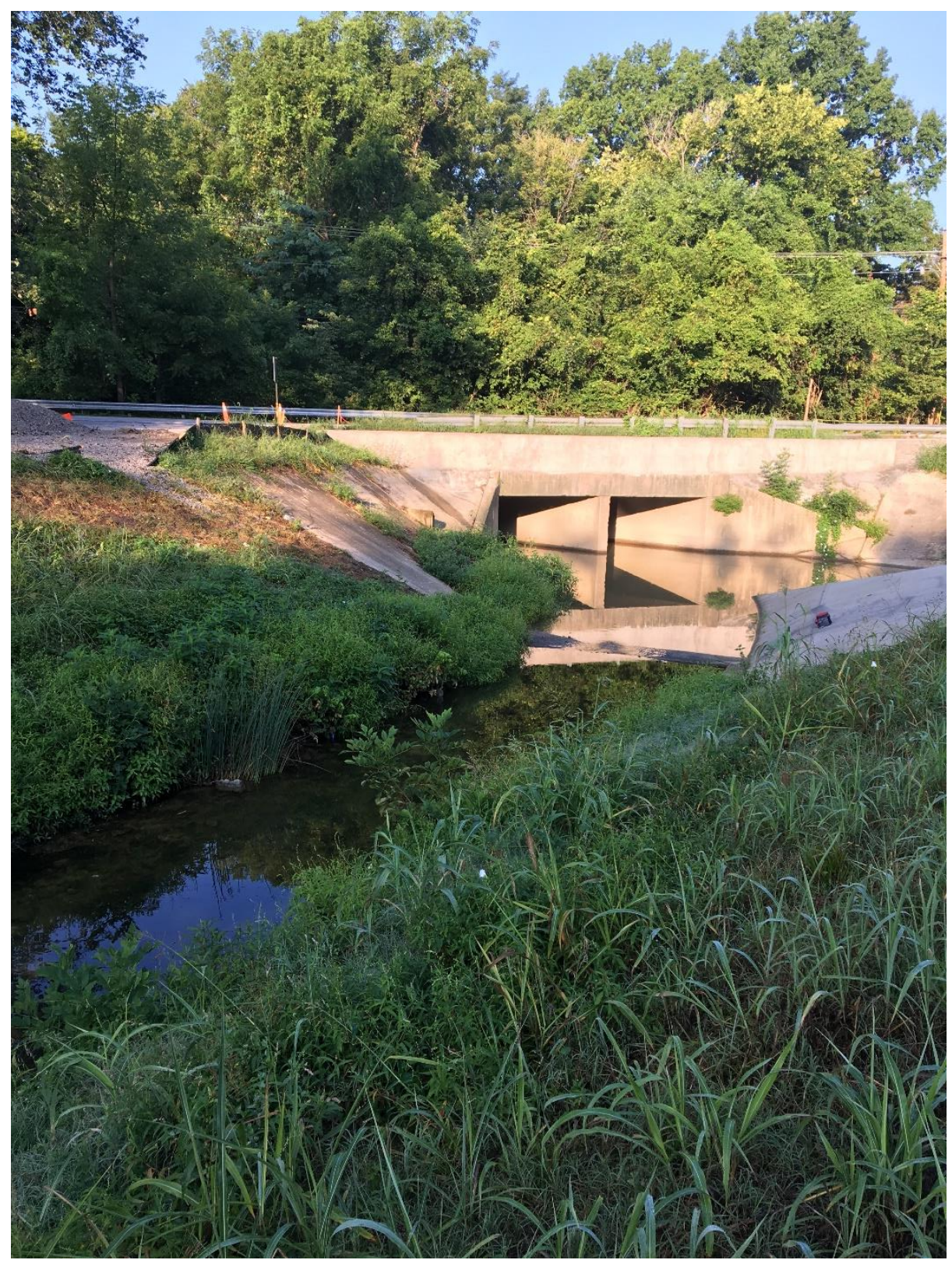

Mill Creek site 4 sampling location 


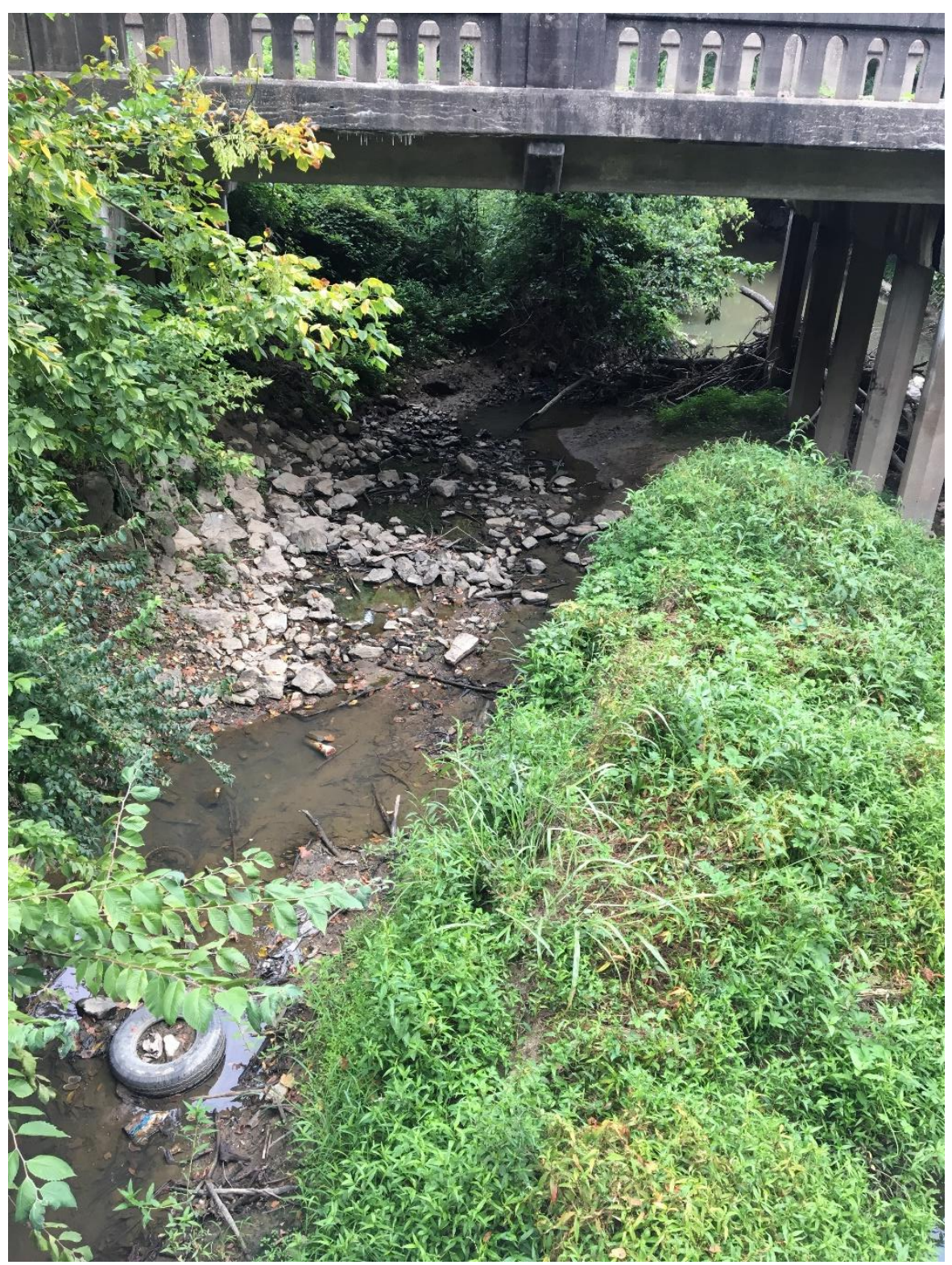

Mill Creek site 5 sampling location 


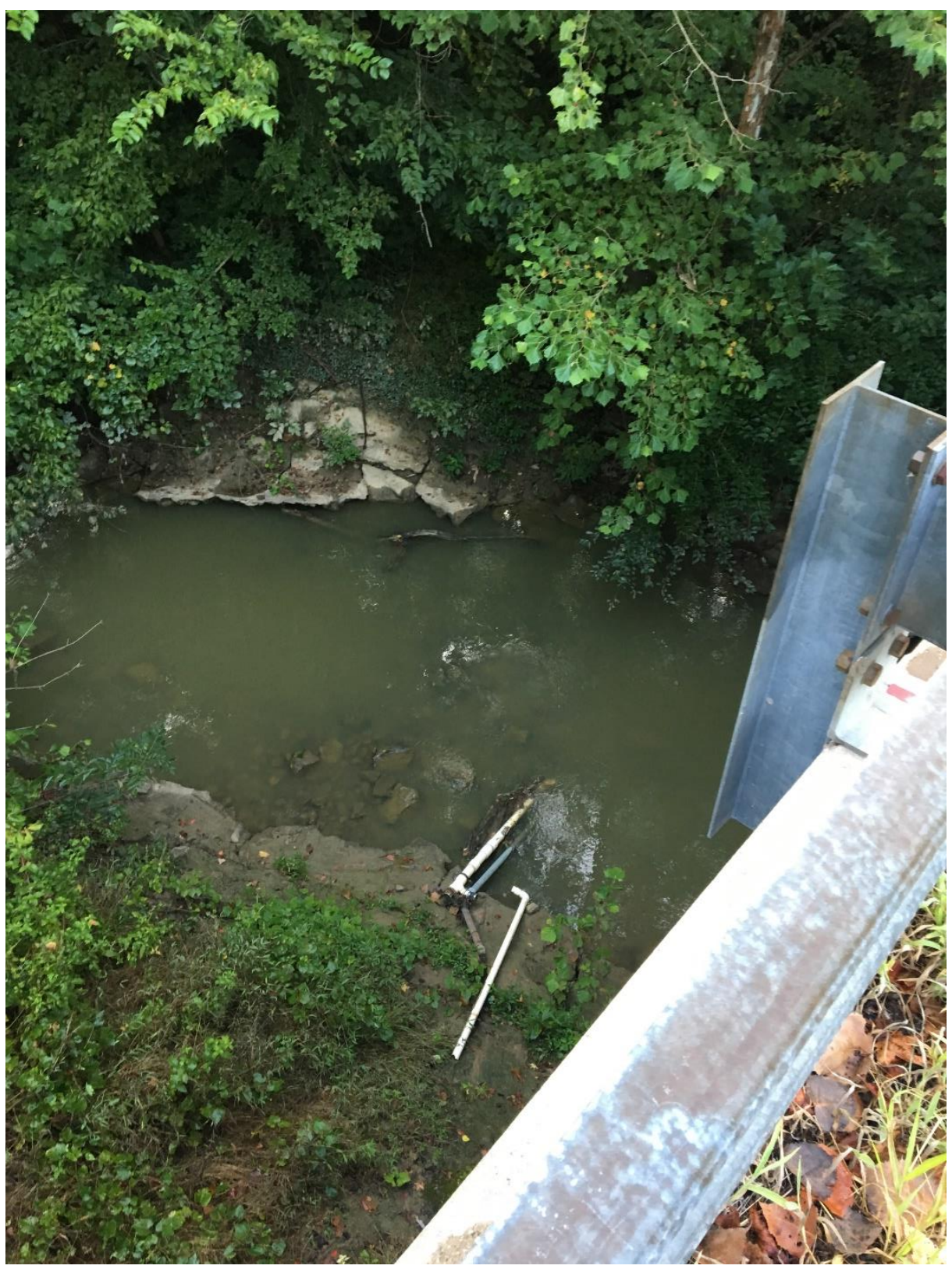

Mill Creek site 6 sampling location 


\section{CURRICULUM VITA}

NAME: Jason Patrik Ingram

ADDRESS: $\quad$ J.B. Speed School of Engineering

220 Eastern Pkwy

University of Louisville

Louisville, KY 40292

PERMANENT ADDRESS:

107 Buttercup ct.

Radcliff, KY 40160

jasonp.ingram@yahoo.com

DOB: $\quad$ November $23^{\text {rd }}, 1993$

EDUCATION \& TRAINING:

B.S., Civil Engineering University of Kentucky

2012-2016

Engineer in Training (E.I.T.)

Kentucky state board of licensure for professional engineers and land surveyors

2018

Certificate of Environmental Engineering

University of Louisville

2019-2020

M.S., Civil Engineering

University of Louisville

2019-2020 